UNIVERSIDADE DE SÃO PAULO

FACULDADE DE FILOSOFIA, LETRAS E CIÊNCIAS HUMANAS DEPARTAMENTO DE LETRAS MODERNAS

PROGRAMA DE PÓS-GRADUAÇÃO EM ESTUDOS

LINGUÍSTICOS E LITERÁRIOS DO INGLÊS

\title{
REGIMES DE VERDADE E REPRESENTAÇÕES CULTURAIS EM LIVROS DIDÁTICOS DE INGLÊS PARA NEGÓCIOS
}

Versão corrigida

Carolina Andrade Ramalho 
Com todo amor, a meu pai (in memoriam), Waldemar, que mesmo tendo partido enquanto eu ainda realizava meus estudos da pós-graduação, trouxeme luz e força para continuar.

A Deus, pelas escolhas certas. À minha mãe, Maria de Lourdes, pelo amor incondicional e força interior.

Às amigas Verônica, Flavia e Adriana, que sempre estiveram ao meu lado e me apoiaram na realização dos meus estudos. 


\section{AGRADECIMENTOS}

À Anna Maria Grammatico Carmagnani pela orientação e compromisso com todas as etapas da pós-graduação, tanto para comigo como para com os colegas.

À Marisa Grigoletto, pelas sugestões no exame de qualificação bem como pelos votos de sucesso ao longo desses anos de estudo.

A Carlos Renato Lopes, pelas orientações no exame de qualificação e ao longo da pós-graduação e também como grande colaborador nas reuniões em grupo.

A meus colegas da pós-graduação, pelo apoio e amizade.

À CAPES, pela concessão da bolsa de estudos. 
RESUMO

ABSTRACT

INTRODUÇÃO

CAPÍTULO 1: CONDIÇÕES DE PRODUÇÃO DO LIVRO DIDÁTICO DE INGLÊS PARA NEGÓCIOS ...................................................................... 12

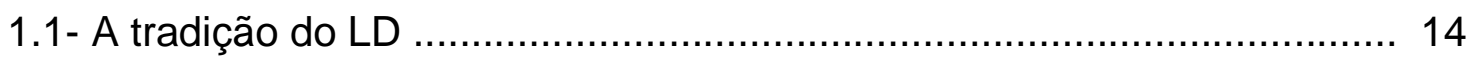

1.2- O LDIN: público-alvo, abordagem e materiais de apoio …………….......16

1.3- Aluno-cliente: a abordagem comunicativa no discurso neoliberal ............ 17

1.4- Os diferentes formatos do LDIN frente às mudanças político-econômicas e

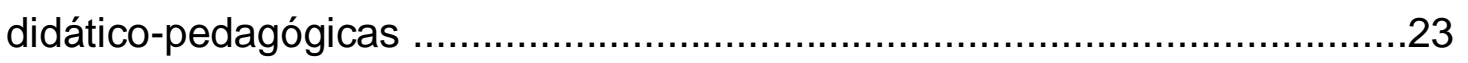

1.5- O inglês para fins específicos como berço para o inglês para negócios....32

CAPÍTULO 2: MODOS DE FUNCIONAMENTO DO LDIN COMO UM

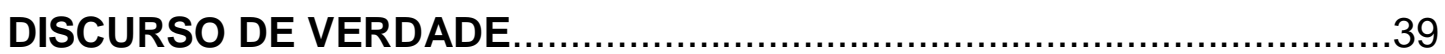

2.1- A autenticidade como discurso verdadeiro..............................................4

2.2- A homogeneização das vozes ...................................................... 53

2.2.1- A inclusão pronominal do interlocutor e seu

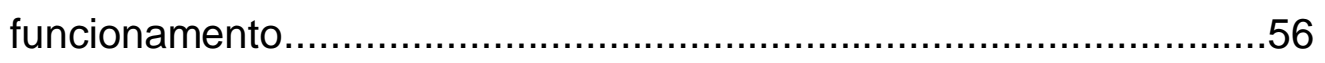

2.2.2- Texto opinativo: presença do autor a partir de juízo de valor...... 61

2.2.3- A heterogeneidade mostrada .................................................. 69

CAPÍTULO 3: AS REPRESENTAÇÕES CULTURAIS SEGUNDO REGIMES DE VERDADE

3.1- Homogeneização dos aspectos culturais .83

3.2- Dicotomia bem $x$ mal: as representações hegemônicas das culturas britânica e americana 100

3.2.1 - A representação dos britânicos 101

3.2.2.- A representação dos norte-americanos

CONSIDERAÇÕES FINAIS

REFERÊNCIAS BIBLIOGRÁFICAS 
O objetivo desta dissertação é analisar o discurso produzido por livros didáticos voltados ao ensino de inglês profissional ou inglês para negócios editados na Inglaterra. Esse tipo de material didático é amplamente utilizado por pessoas que desejam ter acesso a conceitos, expressões e vocabulário relacionados aos negócios, como uma forma de melhorar suas perspectivas profissionais ou obter um emprego para o qual seja necessário saber a língua inglesa. Apesar de serem vistos como mera ferramenta para ensino de língua visando a esse fim, esses livros constituem-se veículos ideológicos e representam geralmente a principal fonte de informação para o aluno, que é constituído por discursos por eles produzidos. Nossa hipótese central é que, embora esse tipo de livro se apresente como um discurso heterogêneo, através principalmente do uso de material autêntico da mídia, são produzidas representações homogêneas das culturas, que são vistas como possuidoras de características ou identidades fixas. Essa hipótese será estudada a partir de uma visão discursiva de linguagem baseada principalmente nos estudos de Michel Pêcheux (1975) e de Michel Foucault (1969, 1971, 1979). Discutiremos como a pluralidade de vozes que constitui os discursos desses livros e as formulações produzidas são homogeneizados e representam um único ponto de vista: o britânico. Dentre as representações presentes, discutiremos como a cultura britânica é vista como benfeitora e exemplar, ao passo que a cultura americana é representada como gananciosa, corrupta e exploradora. Entretanto, o processo de construção desses discursos é apagado, o que faz com que seus usuários tenham a impressão de serem representações neutras e livres de poder. O que contribui para esse apagamento é que o material didático é visto como portador de verdades e fatos inquestionáveis e, além disso, em nosso caso, trazem a mídia impressa como principal fonte de seu conteúdo, que também é considerada como um discurso verdadeiro. Os exercícios propostos de compreensão apenas reforçam essas representações e não questionam seu processo de construção; significados prontos são entregues ao aluno, que não tem a chance de refletir sobre outras interpretações. A análise empreendida indica que, a despeito de 
se apresentar como um discurso heterogêneo, o tipo de livro didático analisado representa as culturas de modo fechado e possuindo identidades fixas, ideia não condizente com a que adotamos.

Palavras- chave: análise de discurso, livro didático, negócios, poder, verdade. 


\section{ABSTRACT}

The objective of this dissertation is to analyze the discourse produced by textbooks aimed at professional or Business English teaching edited in England. This kind of book is widely used by people who want to have access to concepts, expressions and vocabulary related to business, as a way of improving their career prospects or even getting a job which requires prior knowledge of the English language. Despite the fact that they are seen merely as a language tool for the use of professional English learning, textbooks are ideological vehicles and represent the main source of information for the student, who is constituted by the discourses produced by them. Our central hypothesis is that, by means of a discourse that is presented as heterogeneous, mainly by the use of the authentic discourse of the media, these textbooks produce homogeneous representations of cultures, which are depicted as having fixed characteristics and, therefore, fixed identities. This hypothesis will be studied based on a discursive theoretical framework, mainly on the studies of Michel Pêcheux (1975) and Michel Foucault (1969, 1971, 1979). We will discuss how the heterogeneity of voices that constitutes the discourse of these books are homogeneized and represent one perspective: the British one. Among other representations, we will discuss how the British culture is seen as helpful and an example for other cultures, whereas the American one is represented as greedy, corrupt and exploitative. However, the process of the discursive production is silenced, which causes the impression of neutral and power-free representations. What contributes to this silencing is that textbooks are seen as just containing true and unquestionable facts and, in our case, they use the media, also considered the voice of truth, as their main source of information. The reading comprehension exercises proposed just reinforce those representations and do not question their discursive construction; the student is offered closed meanings and does not have a chance to reflect upon other interpretations. The analysis indicates that, despite presenting themselves as a heterogeneous discourse, this kind of book represents cultures as having 
fixed characteristics and that does not correspond to the cultural perspective we adopt.

Keywords: discourse analysis, textbooks, business, power, truth. 


\section{INTRODUÇÃO}

Esta pesquisa tem como objetivo analisar discursivamente livros didáticos britânicos de inglês para negócios (doravante LDIN) no que tange ao modo de construção da verdade nesta materialidade, a partir do processo de produção de sentidos, e refletir sobre os efeitos que este tipo de material produz e suas implicações para a prática da sala de aula. Nosso enfoque recai sobre os livros de origem britânica, dada à maior parte dos livros utilizados hoje em dia, para este fim, serem editados na Inglaterra.

A escolha de trabalharmos com LDINs se deve a duas razões principais. A primeira consiste no fato de que esses livros são amplamente utilizados atualmente como instrumento de ensino de inglês para fins de aprendizado e/ou aprimoramento dos conhecimentos de negócios, que englobam noções sobre as culturas dos países e temas e conceitos relacionados às práticas de negócios. Sua ampla utilização deve-se à exortação ao aprendizado do inglês como pré-requisito para obter sucesso na vida profissional independentemente da profissão escolhida; o mercado de trabalho, constituído pelos ditames da globalização, prega a necessidade de estar bem informado e qualificado, ou seja, o sujeito deve transpor as fronteiras culturais, que hoje não se apresentam como barreiras. As fronteiras territoriais já não representam quase nenhum obstáculo para a comunicação em geral, nem tampouco para a concretização de transações comerciais. Tendo em vista que o inglês é a língua franca oficial dos negócios internacionais e da diplomacia. Lembramos que essa necessidade é instigada também pela mídia que associa ascensão ou sucesso profissional com o domínio do inglês, fazendo com que a língua seja vista como, cada vez mais, indispensável. Não saber inglês, hoje, é visto como um grande empecilho para aquele que deseja obter e manter um (bom) emprego. Além do mais, a existência desta modalidade de inglês é relativamente nova se comparada ao ensino do inglês 'geral' ${ }^{1}$ e, por isso, novas pesquisas se fazem necessárias.

\footnotetext{
${ }^{1}$ A tendência ao enfoque do inglês para fins de negócios remonta aos anos 60 , tema de que trataremos em detalhe no capítulo 1.
} 
Outra razão fundamental para a elaboração desta pesquisa consiste no fato de que o LDIN constitui-se um veículo ideológico que tem importante papel como construtor de identidades e do imaginário sobre o outro estrangeiro, fato já observado por CORACINI (1995; 1999), representando, muitas vezes, a única fonte de conhecimento por parte do aluno e, também, do professor. Entretanto, o que se tem observado é que há poucos trabalhos que questionam o conteúdo veiculado em livros didáticos em geral e com relação ao livro de inglês para negócios essa investigação é incipiente.

Os livros didáticos em geral são geralmente seguidos passo a passo e utilizados como referência no ensino, conforme observado por SOUZA (1995). Além disso, há poucas pesquisas que focam a pertinência ou relevância do que se veicula no livro didático. A autora afirma que o livro didático é considerado lugar do não questionamento, da verdade dos fatos, como se o livro fosse um espaço da implantação do que é certo, imparcial e não passível de informações equivocadas. CORACINI (1999) afirma que o que encontramos são estudos que focam no conteúdo linguístico ou pedagógico de livros didáticos, mas uma análise que se detenha na produção de sentido não é, de fato, empreendida. Tal atitude pode ocorrer pelo fato de o livro didático ser considerado um lugar onde não há ideologia, como se a ele fosse possível conter apenas a língua enquanto seu aspecto formal ou lexical (forma abstrata, -sem ideologia, portanto) como objeto de estudo.

O termo 'inglês para negócios' surge a partir de uma nova tendência no ensino de línguas, o inglês para fins instrumentais. De acordo com SWALES (1985), o início da prática desse tipo de ensino no mundo moderno data de 1962, a partir da publicação do artigo 'Some measureable characteristics of modern scientific prose' de Barber. Uma outra versão, citada por BLOOR (1997), defende que a partir da publicação de 'Who with this book shall learn may well enterprise or take in hand merchandise from one land to another', é que tem início a preocupação com a questão mercadológica e a linguagem apropriada para fazer transações. Porém, HOWATT (1984) afirma que foram os anos 60 o marco inicial em que o ensino instrumental começou a tomar forma na área de ensino de inglês como segunda língua e/ou como língua estrangeira, e que, como resultado, os primeiros livros de inglês instrumental foram publicados. Filiar-nos-emos a essa última hipótese. 
Na pesquisa, a abordagem teórica será feita segundo a perspectiva da Análise de Discurso de Linha Francesa (AD), de acordo com o que postulam MICHEL PÊCHEUX (1975) e ORLANDI (1999).

Esta concepção apresenta uma noção não-subjetivista da subjetividade, ou seja, o sujeito não é entendido como aquele criador do discurso que produz, ou sua origem. Segundo PÊCHEUX (1975: 147), 'os indivíduos são interpelados em sujeitos-falantes (em sujeitos de seu discurso) pelas formações discursivas que representam na linguagem as formações ideológicas que Ihe são correspondentes'. Ou seja, o sujeito não é autônomo no que tange à produção de sentidos; estes não são criados a partir dele. Para ORLANDI (1999) o discurso não é tomado como o esquema referentemensagem-código, mas como 'efeito de sentido entre interlocutores', já que não pode ser considerado como tendo um sentido único, previsível pela abstração lingüística ou construído a partir de si próprio, ou seja, ao nível do significante $^{2}$. A língua é considerada a partir de seu caráter material; assim, ela tem opacidade e faz sentido sócio-histórico-ideologicamente; é a materialidade do discurso, e este a materialidade da ideologia. Ela é, também, sujeita a falhas, ao equívoco. As condições de produção são as responsáveis pela instauração do sentido e mantêm com a língua uma relação necessária. São da ordem tanto das circunstâncias de enunciação e do exterior (contexto sóciohistórico-ideológico). A ideologia não é concebida como ocultamento, mas como condição necessária no discurso; além disso, é próprio de seu trabalho produzir evidência, apagando o processo de constituição de sentidos.

Nossa hipótese nesta dissertação é que, embora a heterogeneidade signifique a presença do outro, ou seja, todo discurso constitui-se a partir do outro, o modo como este é representado no LDIN produz uma homogeneização dos sentidos, tanto das vozes que falam, mas também do que é falado, e este funcionamento ocorre uma vez que há apagamento do processo de construção de sentido nesse tipo de material.

Essa hipótese será estudada a partir de um corpus composto por quatro coleções de livros britânicos de inglês para negócios, editados na Inglaterra.

\footnotetext{
2 'Significante' quer dizer 'da palavra enquanto dotada de um sentido se não único, pelo menos previsível pelas condições de produção imediatas de um texto'
} 
Verificaremos como os sentidos são produzidos segundo regimes de verdade e que assim se mantêm como unidades homogêneas; além disso, discutiremos como eles interferem na produção e reprodução de um discurso circular, que não abre possibilidade para outras interpretações.

Esta dissertação é composta por três capítulos, além desta introdução e da conclusão.

O primeiro capítulo tece considerações acerca das condições de produção que constituem o discurso do LDIN, tanto no sentido estrito como no sentido amplo. Também compreenderemos em que medida seu formato modificou-se a partir da última década, ao objetivar responder às novas necessidades que surgiram a partir da conjuntura sócio-econômica que então se configurava: o discurso neoliberal e a política da Gestão da Qualidade Total.

O segundo capítulo consiste na análise de formulações nos livros de nosso corpus, buscando compreender o modo de produção da verdade, ou seja, como o processo de construção de sentidos de 'verdade' funciona, pautada no termo autenticidade e que, a partir deste, faz funcionar discursos aceitáveis na sociedade. As vozes de locutores e enunciadores, constituídas pelo discurso da verdade, fazem circular um discurso que embora se apresente como heterogêneo, produz uma homogeneização das vozes.

O terceiro capítulo também analisa formulações, porém o enfoque recai sobre o funcionamento do discurso no LDIN buscando compreender quais efeitos de sentido sobre representação das culturas se formam e se fixam e a implicação desse funcionamento para a prática da sala de aula no que tange à interpretação.

Por último, apresentamos nossas considerações finais, as referências bibliográficas e os anexos. 


\title{
CAPÍTULO 1
}

\section{CONDIÇÕES DE PRODUÇÃO DO LIVRO DIDÁTICOO DE INGLÊS PARA NEGÓCIOS}

Neste capítulo, temos como objetivo discutir as condições de produção do discurso do livro LDIN, a fim de que situemos o discurso no(s) momento(s) de sua produção, resgatando o viés sócio-histórico-ideológico pelo qual seu aparecimento foi possível para que o analista investigue seus efeitos tendo em vista que a evidência ideológica nos priva desse olhar, uma vez que apaga a constituição dos dizeres.

Segundo ORLANDI (1999), as condições de produção (CP) são divididas em dois tipos: as imediatas, ou seja, correspondentes às circunstâncias da enunciação, da qual faz parte o contexto imediato, e as de sentido amplo, que são o contexto sócio-histórico ideológico. Na análise que empreende em seu texto, a faixa 'Vote Sem Medo', colocada na época das eleições em uma universidade, aponta que, no caso em questão:

\begin{abstract}
O contexto imediato é o campus onde a faixa foi colocada, os sujeitos que a "assinam", o momento das eleições e o fato do texto ter sido escrito em uma faixa e não em outro suporte material qualquer. $O$ contexto amplo é o que traz para a consideração dos efeitos de sentidos elementos que derivam da forma de nossa sociedade, com suas Instituições, entre elas a Universidade, no modo como elege seus representantes, como organiza o poder, distribuindo posições de mando e obediência. E finalmente entra a história, a produção de acontecimentos que significam na maneira como cores como o negro está relacionado ao fascismo, à direita, e o vermelho ao comunismo, à esquerda, segundo um imaginário que afeta os sujeitos em suas posições políticas (idem, op. cit., p. 31).
\end{abstract}

As condições imediatas englobam, portanto, os sujeitos e a situação. Em nossa pesquisa, os sujeitos envolvem os alunos e os professores, além dos diretores de escolas, coordenadores de cursos, entre outros profissionais que participam da seleção dos materiais e na forma como o curso deva ser 
conduzido $^{3}$. Já a situação corresponde aos locais onde ocorre o uso desse material, que geralmente é a sala de aula, as escolas e as empresas onde essas aulas são lecionadas. Da situação também fazem parte os elementos discursivos presentes no momento da aula e como eles se organizam como, por exemplo, o quê vai ser ensinado, quais meios são utilizados para desenvolver esse ensino (Internet, gravuras, ilustrações).

O contexto amplo refere-se a quais sentidos circuláveis na sociedade adquirem o status de aceitos ou não, questão que leva em consideração 0 poder de instâncias tais como as instituições, enquanto produtoras/reguladoras de sentidos. Também constitui o contexto amplo a história, ou seja, a produção dos acontecimentos e seus elementos significando de forma específica, produzindo sentidos.

Para a autora (op. cit., p. 31), ainda faz parte das CP a memória, que se define como 'aquilo que fala antes, em outro lugar, independentemente', ou seja, tudo o que já foi dito antes. São os sentidos que os elementos presentes na situação de enunciação já tiveram (os temas dos textos lá encontrados, por exemplo), mas também o que se falou sobre materiais didáticos em geral e de ensino de inglês para negócios em particular, as experiências dos sujeitos que fazem parte da situação, enfim, os sentidos já produzidos e que retornam nos discursos atuais, sustentando-os, produzindo outros.

Assim, nossa reflexão versará sobre os contextos que fazem parte do LDIN, interferindo na produção de seus sentidos, e a memória discursiva. O LDIN surge dentro de um contexto onde a tradição do LD já é estabelecida e no momento em que o discurso neoliberal permeava várias práticas. No campo dos estudos da linguagem, houve uma mudança com relação a como esta devia ser trabalhada. Apontaremos algumas características desses contextos nas próximas seções e abordaremos como elas se fazem presente na materialidade de nosso corpus.

\footnotetext{
${ }^{3}$ Aqui, refiro-me a quaisquer outras orientações que os professores devam seguir segundo a política da escola onde atuam a despeito das características da abordagem comunicativa, que é a metodologia oficialmente adotada pelos livros de nosso corpus.
} 


\section{1- A tradição do LD}

Os LDINs têm sua tradição a partir de livros didáticos em geral, que são materialidades consideradas 'verdades'. O status desse tipo de livro é, portanto, tomado como inquestionável. Nesse sentido, afirmamos que o livro didático tem autoridade. SOUZA (1999: 27) afirma que:

O caráter de autoridade do livro didático encontra sua legitimidade na crença de que ele é depositário de um saber a ser decifrado, pois supõe- se que o livro didático contenha uma verdade sacramentada a ser transmitida e compartilhada.

Essa crença de que fala a autora é criada e alimentada pela sociedade, que define, sócio-historicamente, o que deve ser considerado como importante, passível de validação, enfim, o espaço que determinada materialidade pode, deve, ou, passará a conquistar.

CORACINI (1999: 33) faz uma reflexão acerca dessa legitimação, dizendo que 'legitima-se aquilo que é considerado como tendo um valor, ou seja, como um BEM, em oposição a algo que seria negativo, maléfico, assim considerado pelo indivíduo e pelo grupo social a que pertence'. SOUZA (op. cit., 27) afirma que o que se constata é que o livro didático constitui um elo importante na corrente do discurso da competência: é o lugar do saber definido, pronto, acabado, correto. Quando da escolha do material didático a ser adotado, professores e outros responsáveis pela sua adoção para uso em um determinado curso, na maioria das vezes, questionam se o livro é bom ou ruim em termos de metodologia ou até mesmo aspectos visuais, enfim, características que, segundo eles, não implicam a questão ideológica do conteúdo veiculado.

É, portanto, a partir de sua constituição como um discurso correto e nãoideológico, que podemos caracterizá-lo como uma forma de poder, tema de que trataremos mais elaboradamente no capítulo dois. GRIGOLETTO (1999: 68) afirma: 
O LD é concebido como um espaço fechado de sentidos, e é dessa forma que ele se impõe, e é normalmente acatado, pelo professor. Assim, o seu autor não precisa justificar os conteúdos, a sequencia ou a abordagem metodológica adotadas; não precisa lutar pelo reconhecimento do seu livro como um discurso de verdade; esta caracterização já está dada. A esse respeito, é digno de nota o fato de o livro do professor trazer prefácios curtos, nos quais o autor geralmente não se estende em justificativas sobre a metodologia adotada ou os conteúdos privilegiados, como se tais aspectos já estivessem legitimados a priori.

Portanto, o caráter legitimado ou de 'verdade' do LD já é pressuposto. Seu espaço como 'produtor de verdades' é garantido e validado na e pela sociedade, e não depende de justificativas no tempo e espaço em que são utilizados para se afirmar como um discurso verdadeiro. No caso dos LDINs, o que encontramos são justificativas sobre as fontes dos conteúdos; no caso, os livros de nosso corpus trazem jornais e revistas de grande circulação na Inglaterra. Desse modo, ao justificar a fonte, o conteúdo também se justifica.

Além disso, podemos destacar que os cursos de línguas oferecidos por escolas ou institutos de idiomas são classificados como 'cursos livres' pelo Ministério da Educação e, assim, não estão sujeitos a nenhuma forma de controle ou reconhecimento por parte da referida instituição. Livre, segundo o MEC, significa não ter carga horária mínima, não ter exigência de préqualificação, não ter disciplinas obrigatórias e também não possuir tempo de duração determinado. Diferentemente do ensino fundamental, do ensino médio, cursos técnicos, graduação e pós-graduação, mestrado e doutorado (nos âmbitos públicos e privados) e os EJAS - antigo supletivo, os cursos livres não estão submetidos à legislação. À primeira vista, portanto, esses cursos são produzidos sem o controle oficial e, por esse motivo, são vistos como isentos de elementos sócio-político-ideológicos, já que essa instituição é livre para selecionar o que quiser.

A impressão que pode ser causada, portanto, é que esses materiais sejam neutros, livres, autônomos, desvinculados de políticas. Isso reforça a sua imagem como material isento de forças ideológicas, ou seja, um local onde não há poder. Porém, veremos detalhadamente como o poder está presente nessa materialidade nos capítulos dois e três. 
$\mathrm{Na}$ seção seguinte, faremos considerações acerca de como se apresentam os LDINs, no que tange ao público visado e à metodologia adotada.

\section{2- O LDIN: público alvo, abordagem e materiais de apoio}

Os livros que serão analisados são denominados livros de 'inglês para negócios', ou seja, voltados a atender aos alunos que queiram ou precisem aprender o idioma para fins de negócios; porém, mesmo sendo essa a forma mais comum pela qual se faz referência a esse tipo de material, eles são também denominados de livros para 'inglês profissional' ${ }^{4}$, uma vez que o aluno tem contato com a língua inglesa necessária para o ambiente profissional e não só para 'fazer negócios'. Na seção introdutória de um dos livros ${ }^{5}$ de nosso corpus, encontramos as seguintes formulações referentes ao objetivo do material:

The course is intended for use either by students preparing for a career in business or by those already working who want to improve their communication skills. ${ }^{6}$

No trecho acima, podemos notar a ligação entre mercado de trabalho e saber o idioma inglês, tema que será discutido na próxima seção.

Os LDINs são utilizados por escolas de idiomas tanto nos seus próprios centros de treinamento ou em empresas, onde as aulas também podem ser dadas (são as chamadas 'aulas in-company', ou seja, na própria empresa onde

\footnotetext{
${ }^{4}$ Um dos livros que fazem parte do nosso corpus (Business Start-Up) auto denomina-se 'professional' English. Já os outros, denominam-se 'Business' English.

${ }^{5}$ Market Leader Intermediate Coursebook, 2006, p. 4 (A referência completa dos livros didáticos encontrase na bibliografia; nas notas de rodapé, apenas mencionaremos o nome do LDIN e o ano de publicação).

6 'O curso é voltado não só para alunos que estão se preparando para uma carreira nos negócios, mas também àqueles que já trabalham que queiram melhorar suas habilidades de comunicação'. Market Leader Intermediate. Business English Teacher's Resource Book, 2002, p. 3.
} 
os alunos trabalham). Também são utilizados por professores particulares em empresas ou até mesmo residências. Os que fazem parte de nosso corpus são editados na Inglaterra e produzidos, geralmente, por profissionais da área da Educação também ingleses, mas que trabalharam como professores em outros países, na sua maioria. Estão inseridos, como um deles afirma, dentro da abordagem comunicativa de ensino de língua estrangeira. Um dos livros traz referência à prioridade do foco comunicativo:

Communication skills are highly prioritised, allowing learners to start working in English at the earliest opportunity ${ }^{7}$.

A variante de língua ensinada é o inglês britânico (da Inglaterra); assim, o vocabulário, a pronúncia, a ortografia são desenvolvidos em aula segundo as normas linguísticas do inglês britânico.

Esses livros vêm acompanhados de outros materiais, alguns obrigatórios na compra do livro do aluno; outros, opcionais. Do tipo 'obrigatório', temos o CD de áudio do aluno e/ou CD ROM; já do tipo 'opcionais', temos, por exemplo, DVD, livros de gramática ou dicionários específicos de termos de negócios. Eles são vendidos por grandes livrarias do Brasil e adotados por escolas ou institutos de idiomas.

Na próxima seção, teceremos considerações sobre o contexto amplo, ou seja, apontaremos e discutiremos como os elementos político-econômicos que constituem o momento histórico se articulam com a produção dos LDINs.

\subsection{Aluno-cliente: a abordagem comunicativa e sua relação com 0 discurso neoliberal}

Segundo RICHARDS e RODGERS (1986: 64), a abordagem comunicativa, ou 'Communicative Language Teaching', doravante CLT, teve início na Inglaterra no final da década de 60, período em que ocorreram

\footnotetext{
${ }^{7}$ Afirmação encontrada nas contra-capas dos livros Business Start-Up 1 and Business Start-Up 2.
} 
algumas mudanças relacionadas à tradição no ensino de línguas. Anteriormente, vigorava o 'Situational Language Teaching', abordagem que baseava-se em práticas de estruturas básicas de situações previsíveis, com ênfase em estruturas da língua.

Porém, de acordo com RICHARDS (1994) desde que a teoria linguística subjacente ao Audiolinguismo fora rejeitada nos Estados Unidos em meados dos anos 1960, os linguistas britânicos começaram a questionar as premissas do Situational Language Teaching. Abandonava-se, assim, o paradigma de língua enquanto ferramenta para eventos situacionais previsíveis. Dava-se espaço, assim, à abordagem comunicativa, que parte de uma teoria de língua como comunicação, onde há o primado do significado ('meaning') sobre a estrutura e não foca, como nas abordagens anteriores, em situações previsíveis com suas estruturas e formas correspondentes.

In the 80's the majority of teachers would have been trained within an audio-oral tradition of English language teaching with the implications regarding language and language learning theory that that particular kind of methodology brings with it. (CELANI, 1998: 236)

Dentre algumas características da CLT, podemos destacar: o significado e a contextualização que são primordiais; além disso, as estruturas e formas linguísticas que são internalizadas através de erros e acertos e não pela prática contínua dessas estruturas.

Quanto ao professor de CLT, espera-se que este assuma a responsabilidade de determinar $\mathrm{e}$ atender às necessidades do aluno (RICHARDS e RODGERS, op. cit., p. 78):

This may be done informally and personally through one-to-one sessions with students, in which the teacher talks through such issues as the student's perception of his or her learning style, learning assets, and learning goals. It may be done formally through administering a needs assessment instrument [...]

Essa expectativa de 'responder a necessidades do aluno' ecoa sentidos do discurso da GQT (Gestão da Qualidade Total), que segundo SILVA (2001), 
focava na participação dos "clientes" e na definição dos objetivos e métodos educacionais a partir das necessidades e desejos dos "consumidores". Segundo o autor,

É central, na reestruturação buscada pelos ideólogos neoliberais, atrelar a educação institucionalizada aos objetivos estreitos de preparação para o local de trabalho. No léxico liberal, trata-se de fazer com que as escolas preparem melhor seus alunos para a competitividade do mercado nacional e internacional. (idem, op. cit., p. 12)

No campo da educação, portanto, o objetivo do projeto neoliberal era colaborar para o florescimento das práticas corporativas, da expansão econômica, enfim, ter sua utilidade em termos de resultados.

O neoliberalismo defende a existência de um Estado mínimo, uma vez que considera que problemas como ineficiência e burocracia seriam minimizados ou evitados se houvesse maior participação da iniciativa privada. A partir dela, algumas noções como eficiência e qualidade seriam focos dessa nova política e assim seria possível conquistar melhorias na gestão dos sistemas como os educacionais ou de saúde, por exemplo. SILVA (op. cit., p. 11) afirma:

O discurso liberal atribui à intervenção do Estado e à esfera pública todos os males sociais e econômicos de nossa atual situação e à livre iniciativa todas as virtudes que podem conduzir à regeneração e recuperação da democracia, da economia e da sociedade.

$\mathrm{Na}$ América Latina, o discurso da GQT na educação teve seu início na década de 80, resultado da democratização do ensino. Porém, a passagem de governos autoritários para os democráticos não significou exatamente uma mudança, pois o Estado continuou a exercer controle sobre vários setores tais como a previdência, a saúde e a educação. SILVA (op. cit., p. 18) lembra-nos:

Os problemas sociais e educacionais não são tratados como questões políticas, como resultado -e objeto -de lutas em torno da distribuição desigual de recursos materiais e simbólicos e de poder, mas como questões técnicas, de eficácia/ ineficácia na gerência e administração de recursos humanos e materiais.

Ao traçarmos um paralelo com o ensino de inglês para negócios, o que os LDINs defendem é que conseguir um bom emprego está diretamente 
relacionado ao aprendizado do aluno, ou seja, é uma questão técnica: o aluno precisa se qualificar tecnicamente para estar apto a conseguir um bom emprego.

A questão da qualidade refere-se à obtenção de um uso que pode ser verificado. GENTILI (2001: 139) enfatiza que a 'mensurabilidade sempre foi o aspecto capaz de materializar qualquer aspiração empresarial que tenda a gerar melhorias nos níveis de qualidade'.

Portanto, a ideia que subjaz é que investir no aprendizado de inglês para negócios é investir também na carreira, como apontamos acima, já que a língua será, muito provavelmente, conforme previsão feita pelo mercado, necessária para a entrada neste e sua consequente permanência.

ARAÚJO ${ }^{8}$ (2002: 33) afirma que:

Currículos começam a ser adaptados para suprir as necessidades das empresas e indústrias, ao mesmo tempo em que os pressupostos neoliberais são incutidos na sociedade que passa não só a aceitar essa nova perspectiva, mas também a reforçá-la, acreditando que esta seja a única alternativa válida numa sociedade moderna.

Os materiais com que trabalhamos mencionam estarem em consonância com as exigências do mercado de trabalho por oferecerem um conteúdo que seja útil à vida profissional do aluno. Vejamos as seguintes afirmações encontradas em duas séries diferentes de nosso corpus, onde notamos a ligação entre o inglês e a demanda do mercado de trabalho:

\section{Excerto $1^{9}$}

If you are in business, the course will greatly improve your ability to communicate in English in a wide range of business situations. If you are a

\footnotetext{
${ }^{8}$ ARAÚJO, C.E.B. Ensino Reflexivo e Discurso Neoliberal: Análise de uma Experiência. 2002. 127 f. Dissertação (Mestrado em Estudos Linguísticos do Inglês) -Faculdade de Filosofia, Letras e Ciências Humanas. Universidade de São Paulo. São Paulo. 2002.
}

\footnotetext{
${ }^{9}$ Market Leader Upper Intermediate Business English Course Book, 2006, p. 4.
} 
student of business, the course will develop the communication skills you need and will enlarge your knowledge of the business world. Everybody studying this course will become more fluent and confident in using the language of business and should increase their career prospects.

No excerto acima, o livro afirma que o sujeito aluno falará o inglês mais fluentemente e se sentirá mais confiante, o que aumentará as perspectivas de emprego. Já em outra série, encontramos dois tipos de livros específicos ${ }^{10}$ :

Excerto 2

\section{Learn Business}

What happens when your students haven't worked in business before? They need to learn business concepts like mergers and acquisitions. They need to know essential career skills, like presenting and summarising. On top of this, they need to learn useful business English.

The Coursebook assumes that students have a limited prior knowledge of the business world, so it teaches business concepts and skills as well as business English. ${ }^{11}$

\section{Excerto 3}

\section{Do Business}

Your students don't need to be taught what a multi-national company is, they work for one. They don't need to be taught how to write a business report, they wrote one last week. They just need to turn their familiar work life into English as quickly as possible. The Skills Book includes topics such as 'meeting business partners', 'brainstorming solutions', 'leading a meeting' and 'making a short presentation'.

It provides students with functional business English that they can use at work straight away. There is also a free practice CD ROM with all the listening material and some of the video as well as extra language check activities.

The Skills book can be used with the Course Book to bring more of a skills focus into your classroom, or use it independently for an intensive Business English Skills Course

\footnotetext{
${ }^{10}$ The Coursebook is for students with limited work experience. The Skills Book is for students who have work experience.

${ }^{11}$ Disponível em <http://www.pearsonlongman.com/intelligent_business/course_overview.html>
} 
Nos excertos da série Intelligent Business, 2 e 3, notamos novamente a ligação entre o inglês e sua importância para o mercado de trabalho, tanto para aqueles que ainda não têm contato com o mundo dos negócios (excerto 2) como para aqueles que já o têm (excerto 3). Ou seja, não há quem escape, enquanto 'cliente', dessa necessidade: o inglês para negócios é necessário a todos.

Assim, acreditamos que o discurso do ensino de inglês para negócios adquira ainda mais força e suscite grande interesse por colocar para o sujeito essa possibilidade de ascensão profissional, ou seja, não é, simplesmente, uma questão de saber um idioma como um diferencial, mas como pré-requisito, de modo que não sabê-lo implicará dificuldades na obtenção de um emprego. Ou seja, já que vivemos num contexto sócio-histórico onde a competição acirra-se cada vez mais, as pessoas devem buscar o aperfeiçoamento de seus estudos para obterem um espaço desejável na sociedade. Num mundo onde a rapidez da informação aumenta a níveis exorbitantes, somos chamados a acompanhá-la e mais, somos instados a ceder a discursos tais como 'faça a diferença', 'seja o melhor', 'não perca tempo', 'tempo é dinheiro', 'o inglês já é habilidade pressuposta, tal como o português'.

CARMAGNANI (1999: 128) aponta que o investimento das editoras em livros que se destinam ao ensino de língua estrangeira tende a ser tão alto quanto o retorno que ele proporciona, e como cada vez mais o ensino de inglês é visto como fundamental, a expectativa é que haja sempre maior investimento nesse tipo de material. Acreditamos que os livros didáticos de inglês para negócios, que são produzidos especificamente para esse fim, constituem-se em retorno garantido para as editoras, pois pressupõe trazer o 'inglês' necessário para o mercado de trabalho.

Isso nos remete à ideia de 'saber uma língua' como 'ser portador de uma arma'. SOUZA (op. cit., p. 93) postula que 'se tomarmos o papel do livro didático, mesmo metaforicamente, enquanto 'arma', parece-nos que o sucesso residiria em saber manejá-la, manipulá-la bem'. Ou seja, na guerra por um emprego de destaque, por exemplo, vence quem tem a melhor arma. A autora ainda acrescenta que 'ao manipulá-la, parece também haver implícita a ideia 
de que é possível usá-la enquanto recurso de defesa, em relação a algo perigoso ou em situação que envolva ameaça ou competição'.

A seguir, discutiremos de que formas os LDINs se propuseram a atender à demanda desse mercado.

\subsection{Os diferentes formatos do LDIN frente às mudanças político- econômicas e didático-pedagógicas}

Os livros de inglês para negócios publicados antes do ano de 2000 apresentavam um conteúdo primordialmente voltado a situações lingüísticas de comunicação: não havia praticamente nenhum tipo de texto; o foco eram estruturas gramaticais, modelos de pronúncia, funções comunicativas, ou seja, a língua enquanto ferramenta comunicativa.

Vejamos recortes de tabelas que apresentam os conteúdos das unidades em dois livros de inglês para negócios publicados antes de 2000. A seguir, temos exemplos das primeiras unidades:

Tabela $\mathrm{A}^{12}$

\begin{tabular}{|l|l|l|l|l|}
\hline \multicolumn{1}{|c|}{ Unit } & & $\begin{array}{l}\text { Communication } \\
\text { Skills }\end{array}$ & $\begin{array}{l}\text { Language } \\
\text { Knowledge }\end{array}$ & \multicolumn{1}{|c|}{$\begin{array}{c}\text { Telephone } \\
\text { Practice }\end{array}$} \\
\hline 1 & $\begin{array}{l}\text { First Contact } \\
\text { p. } 8\end{array}$ & $\begin{array}{l}\text { Preparing for a } \\
\text { telephone call }\end{array}$ & $\begin{array}{l}\text { Key } \\
\text { vocabulary } \\
\text { about } \\
\text { telephoning }\end{array}$ & $\begin{array}{l}\text { Preparing } \\
\text { and making } \\
\text { calls }\end{array}$ \\
\hline 2 & $\begin{array}{l}\text { The Right } \\
\text { Person p. 14 }\end{array}$ & $\begin{array}{l}\text { Explaining the } \\
\text { purpose of a } \\
\text { call }\end{array}$ & Opening calls & Opening calls \\
\hline
\end{tabular}

Recorte $\mathrm{B}^{13}$ :

\footnotetext{
${ }^{12}$ Effective Telephoning, 1998, p. 4.

${ }^{13}$ Business Opportunities, 1998, p. 2.
} 


\begin{tabular}{|c|c|c|c|}
\hline Topic & Language & Vocabulary / • Pronunciation & Skills Work \\
\hline \multirow{3}{*}{$\begin{array}{l}\text { Getting acquainted } \\
\text { Executive titles } \\
\text { Management styles } \\
\text { Time management } \\
\text { Jobs quiz } \\
\text { Employment }\end{array}$} & \multirow{3}{*}{$\begin{array}{l}\text { Introductions } \\
\text { Question forms } \\
\text { Tense review }\end{array}$} & Employment verbs network & \multirow{3}{*}{$\begin{array}{l}\text { Speaking: } \\
\text { briefing a-new } \\
\text { assistant } \\
\text { Listening: } \\
\text { a corporate } \\
\text { reorganization }\end{array}$} \\
\hline & & Work verbs & \\
\hline & & - Word stress & \\
\hline \multicolumn{4}{|c|}{2 Telephoning to Make Arrangements } \\
\hline Topic & Language & Vocabulary / • Pronunciation & Skills Work \\
\hline \multirow{2}{*}{$\begin{array}{l}\text { Polite questions } \\
\text { Starting and finishing calls } \\
\text { Telephone quiz } \\
\text { Making appointments } \\
\text { Changing arrangements }\end{array}$} & \multirow{2}{*}{$\begin{array}{l}\text { Present and past } \\
\text { continuous tenses } \\
\text { (future time) } \\
\text { Would in polite questions } \\
\text { Telephone language }\end{array}$} & $\begin{array}{l}\text { Phrasal verbs } \\
\text { Expressions for telephoning }\end{array}$ & \multirow{2}{*}{$\begin{array}{l}\text { Listening: } \\
\text { arrangements for a } \\
\text { conference } \\
\text { Speaking 1: } \\
\text { arranging a schedule } \\
\text { Speaking 2: } \\
\text { arranging a meeting }\end{array}$} \\
\hline & & $\begin{array}{l}\text { - three } / \theta / \\
\text { then /d/ } \\
\text { see /s/ } \\
\text { Thursday /z/ }\end{array}$ & \\
\hline
\end{tabular}

Ao analisarmos as tabelas de conteúdos nos dois livros, notamos que o foco recai sobre a língua enquanto estrutura. Em A, temos as seções 'Communication Skills', 'Language Knowledge' e 'Telephoning Practice'. Já em B, temos 'Topic', 'Language', 'Vocabulary/ Pronunciation' e 'Skills Work'. Não há uma seção dedicada à leitura, por exemplo.

O tabela A faz parte de uma coleção da Oxford University Press intitulada Effective. Essa série é composta por cinco livros, cada um com um enfoque diferente: Effective Presentations; Effective Meetings; Effective Negotiating; Effective Telephoning; Effective Socializing. O recorte B foi também retirado de uma coleção publicada pela Oxford que se chama Business Opportunities. A coleção também traz o livro Business Objectives, que geralmente é adotado antes do livro Business Opportunities.

As tabelas de conteúdos das unidades dos livros a partir do ano de 2000 trazem categorias diferentes. Vejamos dois exemplos: 
Recorte $C^{14}$ :

\begin{tabular}{|c|c|c|c|c|c|}
\hline & Discussion & Texts & Language work & Skills & Case study \\
\hline $\begin{array}{l}\begin{array}{l}\text { Unit } 1 \\
\text { Brands }\end{array} \\
\text { page } 6\end{array}$ & $\begin{array}{l}\text { Talk about your } \\
\text { favourite brands } \\
\text { Discuss two } \\
\text { authentic product } \\
\text { promotions }\end{array}$ & $\begin{array}{l}\text { Reading: Outsourcing } \\
\text { production - } \\
\text { Financial Times } \\
\text { Listening: An interview with } \\
\text { a brand consultant }\end{array}$ & $\begin{array}{l}\text { Words that go with } \\
\text { brand and product } \\
\text { Present simple and } \\
\text { present continuous }\end{array}$ & $\begin{array}{l}\text { Taking part in } \\
\text { meetings } 1\end{array}$ & $\begin{array}{l}\text { Caferoma: Solve the } \\
\text { problems of a } \\
\text { leading brand } \\
\text { Writing: e-mail }\end{array}$ \\
\hline $\begin{array}{l}\text { Unit } 2 \\
\text { Travel }\end{array}$ & $\begin{array}{l}\text { Talk about your } \\
\text { travel experiences }\end{array}$ & $\begin{array}{l}\text { Reading: Air rage - } \\
\text { Guardian } \\
\text { Listening: A business } \\
\text { traveller's priorities }\end{array}$ & $\begin{array}{l}\text { British and American } \\
\text { travel words } \\
\text { Talking about the } \\
\text { future }\end{array}$ & $\begin{array}{l}\text { Making } \\
\text { arrangements } \\
\text { on the } \\
\text { telephone }\end{array}$ & $\begin{array}{l}\text { Work, rest and play: } \\
\text { Choose a suitable } \\
\text { hotel for a seminar } \\
\text { in France } \\
\text { Writing: e-mail }\end{array}$ \\
\hline
\end{tabular}

Recorte $D^{15}$

\begin{tabular}{|c|c|c|c|}
\hline Unit and Topics & $\begin{array}{l}\text { Communication skills } \\
\text { and tasks }\end{array}$ & $\begin{array}{l}\text { Reading and listening } \\
\text { texts }\end{array}$ & $\begin{array}{l}\text { Grammar and Lexis } \\
\text { links }\end{array}$ \\
\hline $\begin{array}{l}1 \text { International English p. } 4 \\
\text { Talking points } \\
\text { English as a global } \\
\text { Language }\end{array}$ & $\begin{array}{l}\text { Completing a needs } \\
\text { analysis } \\
\text { Doing a quiz on } \\
\text { languages } \\
\text { Discussing attitudes to } \\
\text { English using } \\
\text { expressions for talking } \\
\text { about language needs } \\
\text { \& learning preferences }\end{array}$ & $\begin{array}{l}\text { R Articles about English } \\
\text { dominating the world } \\
\text { communications } \\
\text { L People talking about } \\
\text { their attitudes to } \\
\text { learning English }\end{array}$ & \\
\hline $\begin{array}{l}2 \text { Making contacts } \\
\text { p. } 6 \\
\text { Networking }\end{array}$ & $\begin{array}{l}\text { Describing people } \\
\text { Discussing appropriate } \\
\text { topics }\end{array}$ & $\begin{array}{l}\text { Extracts from a } \\
\text { business travel } \\
\text { programme on } \\
\text { conference venues }\end{array}$ & $\begin{array}{l}\text { G Present Simple } \\
\text { Present Continuous } \\
\text { Present Simple X } \\
\text { Present Continuous }\end{array}$ \\
\hline Conferences & $\begin{array}{l}\text { Keeping the } \\
\text { conversation going } \\
\text { Networking }\end{array}$ & $\begin{array}{l}\text { People gossiping at a } \\
\text { conference } \\
\text { People socialising at a } \\
\text { conference }\end{array}$ & $\begin{array}{l}\text { LL Colocations relating } \\
\text { to conferences } \\
\text { Verb + prepositions }\end{array}$ \\
\hline
\end{tabular}

Nesses dois recortes, diferentemente de A e B, visualizamos a presença de seções que contemplam leituras: no $C$, a seção 'Texts' e no $D$, a seção 'Reading and Listening Texts'.

\footnotetext{
${ }^{14}$ New Edition Market Leader Intermediate Business English Course Book, 2006, p. 2.

${ }^{15}$ In Company Intermediate Teacher's Book., 2002, p. 2.
} 
Nosso corpus é composto por livros britânicos utilizados atualmente, que são os do tipo que contêm textos, ou seja, publicados a partir do ano de 2000 , devido a contemplarem temas, conceitos, fatos relacionados a empresas, através, principalmente, de conteúdos textuais chamados de 'autênticos' (conceito que será explorado no capítulo 2), que englobam, primordialmente, artigos jornalísticos da mídia britânica.

As unidades desses livros são divididas em seções, que variam conforme a coleção. Alguns exemplos dessas seções são 'communication', 'texts', 'language work', 'skills', 'case study', procurando, assim, sair de um modelo focado somente na gramática e proporcionar ao aluno um trabalho com textos.

Os livros analisados são publicados por editoras de grandes universidades inglesas, como Cambridge $^{16}$, Longman $^{17}$ e Oxford $^{18}$. Encontramos na Internet mais informações sobre essas editoras como, por exemplo, quantos escritórios possuem no Brasil e no mundo, quem são os autores que produzem os materiais, bem como os objetivos educacionais e culturais na produção desses materiais.

Os textos que fazem parte deste tipo de livros didáticos para ensino profissional são extraídos da mídia impressa (ou imprensa escrita) britânica; jornais como The Financial Times e The Guardian e revistas como The Economist são fonte de informação para seu conteúdo e base para a maioria dos exercícios das unidades. Um dos livros, Intelligent Business, apresenta em seu site ${ }^{19}$ um vídeo no qual alguns de seus autores justificam a importância de o livro ter a revista The Economist como fonte principal de conteúdo. Uma das

\footnotetext{
${ }^{16}$ Disponível em <http://www.cambridge.org.br/cambridge-brazil/about-us>

${ }^{17}$ Disponível em <http://www.pearsonelt.com/>

${ }^{18}$ Disponível em <http://www.oup.com.br/oxford-brasil>

${ }^{19}$ A entrevista, na íntegra, está disponível em

$<$ http://www.pearsonlongman.com/intelligent_business/video.html>
} 
autoras afirma na entrevista: 'it's the only course that mirrors a magazine, so when the students pick it up they really feel they are getting an authentic link between the professional business world and the classroom'.

Já um outro livro de nosso corpora, Market Leader, traz dois tipos de logo do Financial Times, anunciando que esse jornal será a fonte de informação de seu conteúdo. O LDIN Intelligent Business traz o logo da revista The Economist na capa.
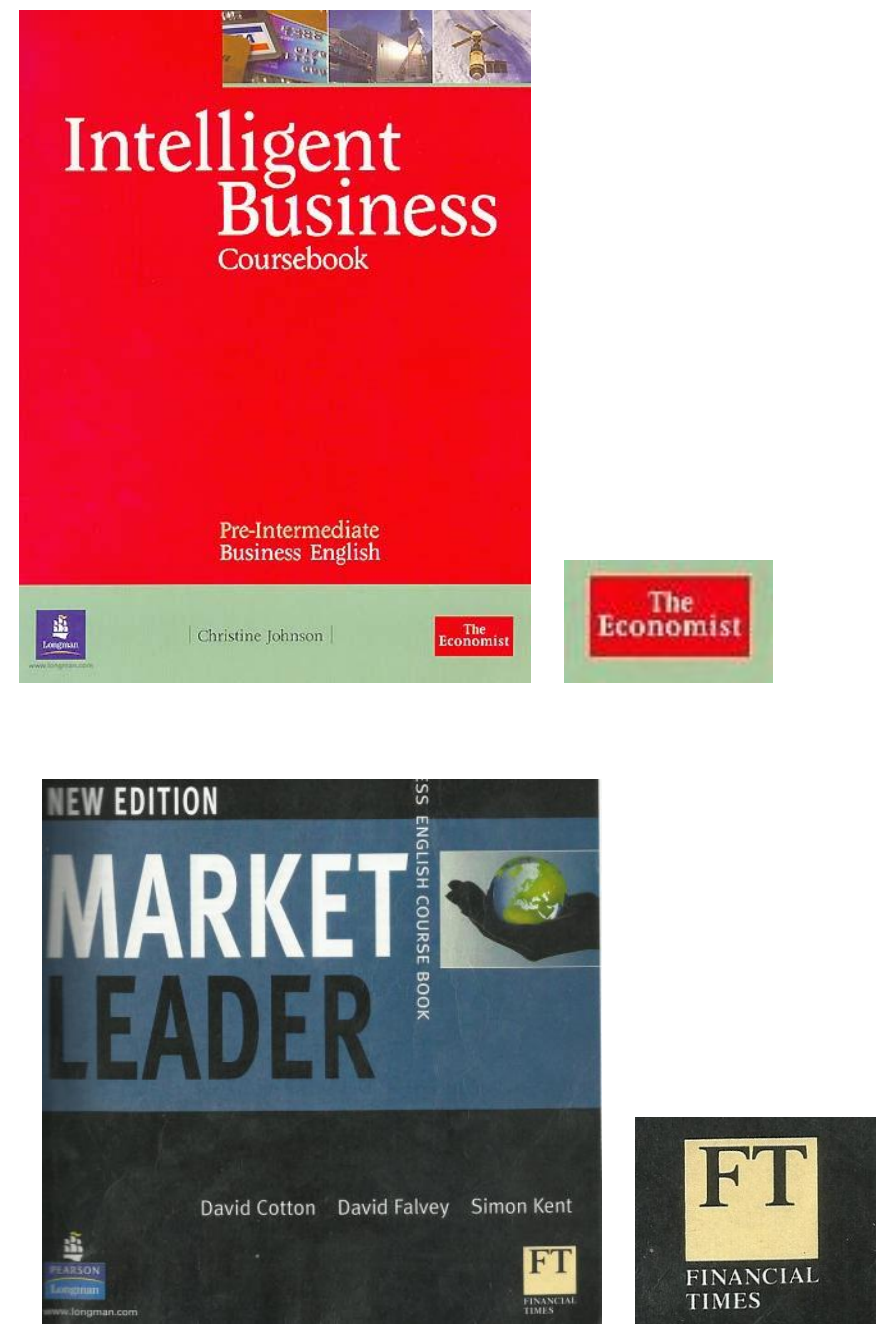

Já as séries In Company e Business Start-Up não mencionam em suas seções introdutórias a sua 'fidelidade' a textos de determinado jornal ou revista. 
Na última página desses livros, encontramos referências sobre os jornais ou revistas utilizados, com data de publicação. Alguns artigos/imagens presentes no livro não têm referência, mas o livro traz uma justificativa para essa ausência:

Although we have tried to trace and contact copyright holders before publication, in some cases this has not been possible. If contacted we will be pleased to rectify any errors or omissions at the earliest opportunity. ${ }^{20}$

Os alunos que utilizam esse material são funcionários de empresas que utilizam ou precisam utilizar o inglês nas mais diversas situações profissionais (participar de reuniões presenciais ou teleconferências, viajar a negócios, ler e compreender manuais ou legislação acerca de seu objeto de trabalho etc). Basicamente, a diferença entre o material regular do ensino de inglês e o de negócios reside no vocabulário: seções com ensino de estruturas gramaticais, e exercícios de pronúncia estão presentes da mesma forma, porém privilegiam o léxico de negócios.

Geralmente, há mais de um autor envolvido na produção desses livros. É uma característica comum dos LDINs deixar o público informado sobre quem são os autores, quais seus percursos na área da educação, onde lecionam ou já lecionaram, em que instituições e países realizaram seus estudos. A título de exemplo, mencionaremos como é feita a apresentação dos autores.

O livro In Company traz em sua capa a menção a mais de oito autores (de nove a onze autores). Nele também encontramos informações sobre seus autores na Internet. $O$ texto está em primeira pessoa no site em inglês e em terceira pessoa no site em português.

Vejamos dois exemplos ${ }^{21}$ do mesmo autor nos dois tipos de site; o texto reproduzido a seguir se refere ao site em português.

\footnotetext{
${ }^{20}$ Essa informação encontra-se na última página de um dos livros de nossa pesquisa, In Company Elementary. Teacher's Book, 2005.

${ }^{21}$ Esta descrição é encontrada em: http://www.macmillan.com.br/conheca-osautores/detalhe.php?ID=ODE=
} 


\section{Jon Hird}

Jon divide seu tempo entre escrever materiais para o ensino de inglês e lecionar em Oxford, onde trabalha há mais de quinze anos. Já lecionou em Paris, na Macedônia e, por um curto período, na Índia e no Vietnam, enquanto viajava como mochileiro na Ásia.

Esteve envolvido na elaboração de diversas coleções, como coautor de dois níveis da série Move, autor convidado em vários dos componentes de Inside Out e autor de parte do material de recursos da série de livros de inglês para negócios, In Company. Jon também esteve envolvido em vários outros livros de recursos extras no ensino de inglês e projetos de escrita baseados na Internet.

Ele gosta do desafio, tanto no trabalho como autor como no de professor, de tentar fazer das atividades de sala de aula tão significativas, motivadoras e divertidas quanto possível. Ele também aprecia fazer palestras em diferentes países e conhecer professores e alunos conhecedores ou não de seus livros. Atualmente, está fazendo mestrado no ensino de inglês para falantes de outras línguas, com área de interesse em gramática, o que ela realmente é e como é aprendida. Sua ambição é a de um dia encontrar tempo para pegar suas baquetas e tocar bateria. 
Abaixo, a descrição do mesmo autor no site em inglês ${ }^{22}$ :

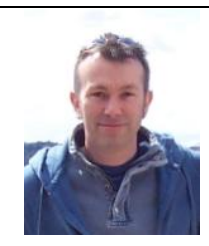

I divide my time between writing ELT materials and teaching in Oxford UK, where I have taught for about twenty years now. During this time I have also taught in Paris and FYR Macedonia.

I have been involved in several ELT courses, including co-writing two levels of the Move coursebook series, writing and contributing to various components of Inside Out and New Inside Out, including the Inside Out Grammar Companions, and writing resource material for the business course In Company. I have also written and contributed to a number of ELT grammar books, resource books and Internet-based writing projects.

I enjoy the challenge, in both my writing and teaching, of trying to make classroom activities as meaningful, engaging and as enjoyable as possible. I particularly enjoy giving talks and workshops in different countries and meeting the teachers and students who may, or may not, use our books.

Em ambas as descrições, há informações quanto ao percurso profissional dos autores.

O texto que precede a descrição dos autores no site em inglês é o seguinte:

Our authors are among the best in the world, each one having many years of experience in their particular area. Find out more about the authors and the books that they have written by choosing from the list below ${ }^{23}$.

No caso da coleção Market Leader, são três autores responsáveis pela produção do material e o histórico de suas carreiras profissionais pode também

\footnotetext{
${ }^{22}$ http://www.macmillanenglish.com/Author.aspx?id=29620

${ }^{23}$ http://www.macmillanenglish.com/Authors.aspx\#
} 
ser encontrado no site da editora ${ }^{24}$. Parte da descrição está reproduzida a seguir:

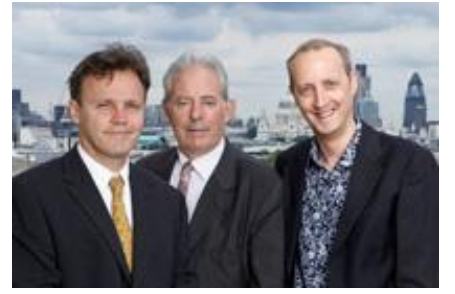

David Falvey (left) has over 20 years' teaching and managerial experience in the UK, Japan and Hong Kong. He has also worked as a teacher trainer at the British Council in Tokyo.

David Cotton (centre) has over 35 years' experience teaching and training in EFL, ESP and English for Business, and is the author of numerous business English titles, including Agenda, World of Business, International Business Topics, and Keys to Management.

Simon Kent (right) has over 15 years' teaching experience including three years as an in-company trainer in Berlin at the time of German reunification. He is currently a Senior lecturer in business and general English, as well as having special responsibility for designing new courses at London Metropolitan University.

Nas descrições em questão, notamos ser recorrente aos materiais oferecerem apresentações que acontecem ou em primeira ou em terceira pessoa, e que sempre se apóiam numa história do percurso profissional e que incluem nomes de instituições onde trabalham ou trabalharam, enfim, sua trajetória profissional e acadêmica e, por vezes, até mesmo seus interesses pessoais. Observe-se que no texto sobre Jon Hird em português aparece uma informação pessoal: seu gosto pela bateria. Já no texto em inglês, não há esse tipo de menção. Acreditamos que a escolha entre mencionar ou não certas informações sobre os autores faça parte do imaginário sobre as culturas que terão acesso à descrição. Dessa forma, pressupõe-se que para os leitores brasileiros seja importante tecer considerações acerca da vida pessoal do

\footnotetext{
${ }^{24}$ http://www.market-leader.net/meet-the-authors.html
} 
autor. Trataremos da questão do imaginário com relação a representações no capítulo 3.

A seguir, mostraremos de que forma o ensino da língua inglesa apresentou modificações à medida que novas necessidades surgiram.

\section{5- $O$ inglês para fins específicos como berço para 0 inglês para negócios}

O ensino de inglês para fins específicos, denominado ESP, não foi um movimento coerente e coeso, segundo HUTCHINSON e WATERS (1987). Nasceu de uma convergência de tendências, dentre as quais podemos considerar três como principais.

A primeira tendência seria que, com o final da segunda guerra mundial, houve uma expansão nas atividades científicas, técnicas e econômicas em todo o mundo. A tecnologia e o comércio atingiram tão altas proporções que logo o progresso exigiria uma língua comum. Com a supremacia dos Estados Unidos no pós-guerra, foi o inglês a língua que prevaleceu. RAMOS (2005) complementa essa necessidade do inglês ao afirmar que era, também, necessário capacitar os imigrantes para que trabalhassem na reconstrução da Europa.

Já a segunda tendência consistiu no fato de que, com a necessidade do inglês para fins específicos, era preciso empreender novos estudos que focassem nesse objetivo. Se tradicionalmente a lingüística se preocupava com as características formais de uma língua, agora era o uso desta numa comunicação real seu foco de interesse (WIDDOWSON, 1978).

O autor (op. cit., 16 et seq) aponta para a diferença entre 'usage' e 'use'. O primeiro termo refere-se à língua enquanto abstração, ou seja, normas ou o sistema linguístico; já o segundo remete ao uso social da língua, a maneira pela qual essas regras são utilizadas nas interações sociais: 
Forma é um aspecto do desempenho, aquele que torna evidente até que ponto o usuário demonstra seu conhecimento de regras linguísticas. O uso é outro aspecto do desempenho: aquele que torna evidente até que ponto o usuário demonstra capacidade de uso do seu conhecimento de regras linguísticas para a comunicação eficaz.

A noção de língua enquanto abstração, segundo o autor, estava sendo atacada. HYMES (1970: 13-14 apud WIDDOWSON, 1973, p. 16), por exemplo, afirma que saber as regras da língua é diferente de saber como usá-las: 'a normal child acquires knowledge not only of grammatical sentences, but also of appropriate ones. He or she acquires competence as to when to speak, when not, and as to what to talk about with whom, when, and where, in what manner'. Portanto, usar a língua não significa somente sabê-la formalmente, enquanto ferramenta, ou seja, suas regras gramaticais, mas saber utilizá-la apropriadamente nas situações de comunicação e em diferentes contextos. Foi essa nova noção de língua que ganhou espaço nos estudos da linguagem.

RAMOS (op. cit., p. 112) afirma que não só mudanças no cenário político-histórico mundial estavam acontecendo, mas também no campo da Linguística e da Psicologia Educacional. Essa nova abordagem nasce a partir de um novo olhar sobre o ensino-aprendizagem, ou seja, de uma nova percepção sobre o que é ensinar e aprender uma língua.

Ainda segundo a autora (op. cit., p. 115), no Brasil, o ESP começou na década de 70 , com o francês como tema na área de ensino-aprendizagem. Somente em fins dessa década que o inglês começou a ser utilizado nessa área: em 1978 foi lançado o Projeto Nacional de Inglês Instrumental, que envolveu diversas universidades brasileiras e tinha o objetivo de aperfeiçoar o conhecimento dos pesquisadores, professores de ciências e técnicos, especialmente com relação à leitura de publicações técnicas e especializadas. Após um primeiro diagnóstico, foi verificado que havia necessidade, por parte dos alunos, de saber ler textos especializados, e, assim, o ensino-instrumental, sobretudo nas universidades, privilegiava a leitura. Essa nova forma de trabalhar a língua constituiu-se num desafio para os docentes, que estavam acostumados com abordagens que privilegiavam as quatro habilidades (escrita, escuta, fala e leitura). Os docentes de universidades e escolas técnicas viram- 
se em face dessa mudança de abordagem, que não ocorreu de forma homogênea:

Some teachers faced the new challenge with interest, perhaps because they felt the need for change in their practice, but others would feel that after all they had been prepared to teach literature or language to future teachers of English and were not interested in this apparently more limited and restricting teaching context. Others yet might feel that they had chosen an arts degree and were now being thrown into a hard sciences context which they did not particularly liked or even feared. (CELANI, op. cit., 235)

DUDLEY- EVANS e ST. JOHN (1998) também refletem acerca do desafio do professor de inglês para negócios quanto ao conhecimento da nessa área:

\begin{abstract}
Most EBP teachers have not worked in business; they cannot say of budget-setting meetings or sales negotiations, 'been there, done that'. In non- EAP situations fewer teachers have experience of or actually work within their students' context. Acquiring such knowledge and skill takes time and comes from reading, from talking to people -perhaps shadowing them at work -from attending courses and conferences, and through experience (op. cit., p. 60)
\end{abstract}

Os docentes também tiveram que elaborar seus próprios materiais, ou adaptar os já existentes, pois os materiais disponíveis no mercado já não supriam essa nova necessidade que passou a ser focada em leitura. No caso do ensino do inglês, foi constatado que havia grandes diferenças lingüísticas para diferentes profissionais, como engenheiros e comerciantes. Assim, se a língua se modifica de acordo com a situação, seria possível fazer um recorte para situações específicas e então tê-las como base para a constituição do curso ou elaboração do livro do curso para o aprendiz.

A terceira tendência motivadora do ESP se refere à ênfase que foi dada ao aluno e suas atitudes como principal foco de preocupação. Foi observado que alunos têm diferentes necessidades e interesses, e que um enfoque que leva esses fatores em conta aumentaria a motivação em aula e teria papel fundamental na efetividade do aprendizado. 
Podemos concluir, portanto, que o ESP inicialmente objetivava um ensino instrumental, de leitura e compreensão, e por isso havia mais textos escritos que orais e que, embora o ensino de inglês para negócios viesse no bojo do ESP, não é a forma inicial do ESP que prevalece hoje. O que temos atualmente são materiais que não focam somente em leitura e compreensão de textos, mas em todas as outras habilidades (como pronúncia, escrita, compreensão oral e fluência), denominado modo 'comunicativo'. O próprio formato do LDIN se modificou: antes focado em estruturas e habilidades comunicativas previsíveis, a partir dos anos 2000 constitui-se de textos sobre culturas, tema que será explorado no capítulo dois.

De acordo com DUDLEY- EVANS e ST JOHN (op. cit.), o advento do ensino de inglês focado em situações de negócios faz parte de uma das fases constituintes do ESP, cuja ênfase inicial era dada a textos acadêmicos (EAP), seguido do EOP, ou English for Occupational Purposes, e somente mais tarde o EBP, ou English for Business Purposes. Isso porque:

In recent years the massive expansion of international business has led to a huge growth in the area of English for Business Purposes (EBP). Within ESP the largest sector for published materials is now that of Business English and there is burgeoning interest from teachers, publishers and companies in this area. (op. cit., p. 2)

CHEW (1999) também faz uma reflexão acerca da importância da língua inglesa no mundo atualmente:

English is indisputably the language of international communication. It has official status in 60 countries and a prominent place in 20 more (Johnson, 1996). It is the main language of books, academic journals, the media and international sports and entertainment. The $20^{\text {th }}$ century has witnessed the emergence of a world language with no close rival and, while it is a familiar phenomenon for one language, for example, Sanskrit, Greek, Latin, Arabic, and French to serve as a lingua franca over a large area of many languages, what is unusual is that never before has a single language spread for such purposes over most of the world as English has done in this century (idem, op. cit, p. 37).

Essa importância comunicativa do inglês se reflete no LDIN, uma vez que este adota a abordagem comunicativa, como vimos anteriormente. O LDIN parte do pressuposto de que o aluno precisará realizar atividades de interação 
com outras pessoas no ambiente de trabalho ou até fora dele e que para isso precisa: enviar e-mails, participar ou conduzir reuniões, representar a empresa numa viagem a negócios, ou seja, articular habilidades que exigem do aluno/profissional certas noções e atitudes que uma metodologia primordialmente focada em textos não seria suficiente.

DUDLEY- EVANS e ST. JOHN (op. cit., p. 53) confirmam essa necessidade:

English has become the international language of business. A Finn conducting business in South Korea uses English; a Brazilian doing business with the Dutch uses English; the French in China often use English; and an American and a German probably also employ English. Thus most English-medium communication in business are non-native speaker to non-native speaker (NNS-NNS), and the English they use is International English, not that of native speakers (NS) of English-medium countries such as the UK and Australia.

Um dos livros de nosso corpus dialoga com essa tendência; observe-se a seguinte informação:

In Company is Macmillan's skills-based Business English series, aimed at professional, adult learners seeking to realize their full potential as speakers of English at work -both in and out of the office - and in social settings. It aims to provide learners with the language and skills they need using motivating and engaging material. Authentic and realistic business stories and situations form the basis for texts, dialogues and speaking activities. ${ }^{25}$ (grifo nosso)

Acreditamos, também, que a necessidade de compreender outras culturas motivou a mudança de conteúdos do LDIN. Era preciso ir além da língua enquanto abstração ou sistema linguístico. Para ter sucesso na interação, seria, então, necessário não só munir-se com o aparato linguístico, mas também com o cultural, ou seja, compreender o outro visando a uma negociação ou interação bem sucedida. E o LDIN, como verificaremos, dentre

${ }^{25}$ In Company Elementary. Teacher's book, 2005, p. 6. 
seus objetivos, procura descrever as culturas, atribuindo-Ihes um modo previsível de lidar com as mesmas, em uma possível transparência. Assim, as culturas são faladas pelos textos presentes no LDIN, enfatizadas através de exercícios e essas descrições tornam-se parâmetros de como lidar, como agir, ou como vê-las, conforme discutiremos no capítulo 3, essa abordagem é via de regra homogeneizante e parcial. Contudo, o discurso do LD busca apagar essa constituição.

A globalização causou um encurtamento de distâncias e uma aproximação cultural, e o que se diz é que temos acesso a todas as informações em tempo real. Se o problema era a dificuldade de obtenção da informação e hoje temos acesso a ela facilmente, o conhecimento está lá, disponível. Basta 'consumi-lo' e, assim, conhecemos o outro e estamos prontos para ter sucesso que, como o lucro, é sempre o maior objetivo dentro do âmbito neoliberal. Quanto a essa questão, DUDLEY- EVANS e ST. JOHN (op. cit., p. 72) lembram-nos do quanto o ensino de inglês para negócios ecoa sentidos do discurso neoliberal:

\footnotetext{
In EBP the purpose is not centred on the learner as an individual, but as a member of a transactional world where the fundamental concern is the exchange of goods or services. Every successful business transaction will impact on other people -from the provider of raw materials, to production staff, to policy makers. Thus there are different priorities: 'knowledge for its own sake' and 'knowledge for a profit margin'.
}

Os livros de nosso corpus são produzidos para circular em vários países, ou seja, várias culturas têm acesso ao seu conteúdo. Além disso, embora em vários momentos nos livros de exercícios e no livro do professor, o LDIN afirmar que seu conteúdo é focado no inglês como instrumento lingüístico, ao observarmos as atividades e as instruções no livro do professor, podemos considerar que há favorecimentos e marginalizações de culturas nacionais, atestando assim seu caráter como veiculador de representações específicas, conforme trataremos no capítulo três.

No presente capítulo, nosso objetivo foi apresentar as condições de produção do LDIN, ou seja, localizá-lo sócio-historicamente e também num 
âmbito mais imediato, que inclui o sujeito-aluno e a situação da sala de aula. Foi também nosso enfoque a apresentação desses livros, ou seja, descrever como eles se apresentam, o que inclui a mudança de conteúdo e estrutura ocorrida a partir de meados de 2000 , quando aspectos culturais passaram a fazer parte de seu conteúdo. Também mostramos de que forma o LDIN se propôs a atender às demandas do projeto neoliberal e ao discurso da GQT, uma vez que buscou justificar seu ensino a partir das necessidades que traziam essas novas perspectivas, além de estabelecer as bases de como 0 LDIN foi constituído como um discurso 'verdadeiro', conforme discutimos no próximo capítulo. 


\title{
CAPÍTULO 2
}

\section{MODOS DE FUNCIONAMENTO DO LDIN COMO UM DISCURSO} DE VERDADE

\begin{abstract}
O político está no fato de que os sentidos são divididos, não são os mesmos para todo mundo, embora pareçam os mesmos. Esta divisão tem a ver com o fato de que vivemos em uma sociedade que é estruturada pela divisão e por relações de poder que significam estas divisões. (ORLANDI, 2009: 12)
\end{abstract}

Este capítulo tem o objetivo de apresentar e discutir algumas formas de produção da verdade que constituem o LDIN e proporcionam seu estabelecimento e permanência como um discurso verdadeiro. Esboçaremos sob quais regularidades a verdade no LDIN existe e faz funcionar seu discurso, ao 'observar os modos de construção do imaginário necessário na produção de sentidos' (ORLANDI, 2007: 18). Assim, através de uma análise discursiva, discutiremos quais e como essas regularidades atuam produzindo alguns efeitos, silenciando outros e as implicações de seu funcionamento na questão da produção do sentido. A importância desta análise baseia-se no pressuposto de que os sujeitos da sala de aula são constituídos na heterogeneidade -são o resultado de uma inúmeras vozes em cruzamento.

Procuramos, assim, responder a algumas questões: De que modo o LDIN pode ser considerado uma materialidade constituída por regimes de verdade? Quais são esses regimes de verdade? Como eles funcionam discursivamente? Quais as implicações de seu funcionamento para os sujeitos constituídos por eles?

A verdade é pressuposta em certos discursos em nossa sociedade. $O$ discurso científico e o jornalístico, por exemplo, são tidos como os locais da verdade, ou seja, como discursos daquilo que é certo, irrefutável. Os livros didáticos também são vistos dessa maneira, ou seja, o que se ensina é o correto. Esses discursos constituem-se, portanto, em 'regimes de verdade', que nas palavras de FOUCAULT (1979a: 12) são: 
os tipos de discurso que a sociedade acolhe e faz funcionar como verdadeiros; os mecanismos e as instâncias que permitem distinguir os enunciados verdadeiros dos falsos, a maneira como se sanciona uns e outros, os meios pelos quais cada um deles é sancionado; as técnicas e procedimentos valorizados na aquisição da verdade; os status daqueles que estão encarregados de dizer o que conta como verdadeiro, "as condições que fazem possível a instauração e manutenção de um saber".

Segundo o autor, toda verdade tem um funcionamento próprio que ocorre graças a condições que permitem sua instauração e manutenção. O LD é considerado um discurso de verdade ou pureza, um local sem ideologia, onde somente a língua como ferramenta ou código será veiculada e ensinada. Seu conteúdo é visto como imparcial, neutro, fonte fiel de referência, lugar de instauração de conhecimento inquestionável. Conforme discutimos no capítulo 1, a aceitação do livro didático na sociedade é ampla, já que é tido como o local da verdade. A partir de SOUZA (1999: 27) o que se constata é que o livro didático constitui um elo importante na corrente do discurso da competência: é o lugar do saber definido, pronto, acabado, correto. O LD não é visto enquanto veículo ideológico.

Podemos afirmar, portanto, que o discurso dos livros didáticos está 'no verdadeiro' dos discursos, ou seja, é tomado como um ponto de convergência e difusão de verdades, por ser um discurso legitimado. É por isso que, no Brasil, assim como em outros países para onde são distribuídos os livros didáticos de inglês para negócios, sua importância é amplamente reconhecida. Uma das razões para tal sucesso constitui-se no fato de serem produzidos a partir de instituições renomadas (Cambridge e Oxford), que são famosas e de prestígio, e o efeito que se tem consiste na aceitação de que esse lugar de saber corresponde a um dizer validado, ou seja, correspondente à verdade. Portanto, a voz de grandes instituições de ensino legitima seu discurso e garante seu sucesso, como aponta FOUCAULT (op. cit., p. 13), sobre a economia política da verdade:

a "verdade" é centrada na forma do discurso científico e nas instituições que o produzem [...]; é objeto, de várias formas, de uma imensa difusão e de um imenso consumo (circula nos aparelhos de educação ou de informação, cuja extensão no corpo social é relativamente grande, não obstante algumas limitações rigorosas); é produzida e transmitida sob o controle, não exclusivo, mas 
dominante, de alguns grandes aparelhos políticos ou econômicos (universidade, exército, escritura, meios de comunicação) [...].

Essa definição de verdade em Foucault facilita a compreensão do LD como um discurso estável. Fica claro, na citação, que a verdade é possível a partir de condições de existência de um discurso e, com relação ao discurso do livro didático, podemos afirmar que as universidades, as escolas, as editoras têm um controle sobre sua criação e distribuição, porém se apresentam como 'pontos neutros' de circulação de discursos. Neutros porque são vistos como puros, sem interesse político -e científicos, ou seja, provados, testados, confirmados. Sendo assim, o poder do LDIN está no fato de este ser concebido como uma forma de acesso incontestável ao conhecimento cultural e a partir desta característica constituir um imaginário sobre o que ali é representado. $O$ LDIN passa a ser parâmetro da verdade cultural, do mecanismo cultural, ou seja, o funcionamento das culturas, que pressupõe ser facilmente descritível.

Por isso, toda verdade é produzida dentro de um conjunto de condições sócio-político-econômicas que atesta sua validade, confere-lhe um status como tal e a faz circular. Uma vez aceita, sua continuidade torna-se possível, pois é regulada por esses meios.

No LDIN encontramos formas discursivas que se dizem comprometidas com o verdadeiro e, assim, constituem-se como regras para implantação da 'verdade'. Assim, a prática discursiva do ensino de inglês para negócios é feita pautada nessas regras, a partir das quais a realidade do mundo dos negócios pode ser trazida para a sala de aula. Segundo o LDIN, a 'autenticidade' consiste em uma das formas pelas quais a realidade é possível, como veremos adiante.

FOUCAULT (1969: 43) denomina essa regularidade como uma 'formação discursiva':

No caso em que entre os objetos, os tipos de enunciação, os conceitos, as escolhas temáticas, se puder definir uma regularidade (uma ordem, correlações, posições e funcionamentos, transformações), diremos, por convenção, que se trata de uma formação discursiva. 
Segundo a definição de ORLANDI (2007: 20) 'as formações discursivas refletem as diferenças ideológicas, o modo como as posições dos sujeitos, seus lugares aí representados, constituem sentidos diferentes'. A partir do momento em que o LDIN trouxe conceitos, temas, noções do mundo dos negócios para seu discurso, e não mais uma abordagem restrita a situações pragmático-lingüísticas previsíveis, atestar ou garantir a 'verdade' tornou-se preocupação e busca constantes. $\mathrm{E}$ a autenticidade constitui-se em uma região válida de dizibilidade, está no que se chama de 'vontade de verdade' de uma época.

Os discursos de verdade dissimulam, na sua transparência, a materialidade que é própria da língua e determina os sentidos.

FOUCAULT (1971: 18) afirma:

Creio que essa vontade de verdade assim apoiada sobre um suporte e uma distribuição institucional tende a exercer sobre os outros discursos -estou sempre falando da nossa sociedade -uma espécie de pressão e como que um poder de coerção.

Segundo o autor (op. cit., p. 37), ninguém entrará na ordem do discurso se não satisfizer a certas exigências ou se não for, de início, qualificado para fazê-lo. E, uma vez qualificado, está no 'verdadeiro', e estando no verdadeiro, tem poder: 'onde há verdade há poder'.

Trataremos do poder não enquanto repressão, mas em seu aspecto sutil: o micropoder (onde parece não haver poder é que este é exercido com mais força). FOUCAULT (1979a: 8) afirma que 'aquilo que faz com que o poder se mantenha e seja aceito é o fato de que ele 'permeia, produz coisas, forma saber, produz discurso'. Trata-se, então, de uma forma de poder mais imediata, como fazendo parte do cotidiano, constitutivo deste.

Partindo dessa premissa, analisaremos o discurso dos LDINs e discutiremos como ele funciona como uma forma de poder. 
DELEUZE (1988: 82) comenta a relação poder-conhecimento:

As ciências do homem não são separáveis das relações de poder que as tornam possíveis e que suscitam saberes mais ou menos capazes de atravessar um limiar epistemológico ou de formar um conhecimento [...].

Assim, podemos afirmar que a verdade é um produto, criada a partir de fatores favoráveis, mas também produz, uma vez que cria outras verdades, que são sustentadas por aquelas que propiciaram seu aparecimento.

Uma análise discursiva busca mostrar o modo de funcionamento e efeitos produzidos pelos regimes de verdade que, por funcionarem pelo trabalho da ideologia, são apagados. Uma vez que são, na evidência, coerências, instauram discursos igualmente evidentes. Por isso que nosso objetivo não é partir deles para analisar seus produtos, mas questionar suas formações para compreender de que forma eles mesmos se constituem. Segundo FOUCAULT (1969: 24):

É preciso pôr em questão essas sínteses acabadas, esses agrupamentos, que na maioria das vezes, são aceitos sem qualquer exame, esses laços cuja validade é reconhecida desde o início [...] e ao invés de deixá-las ter valor espontaneamente, aceitar tratar apenas de uma população de acontecimentos dispersos.

A próxima seção terá, portanto, o objetivo de 'nos inquietar diante de certos recortes ou agrupamentos que já nos são familiares' (Foucault, op. cit: 24). Um exemplo que permeia o discurso desses agrupamentos é o 'discurso autêntico'. Tomado na sua familiaridade, é um discurso coerente.

Desse modo, articularemos os conceitos de verdade e poder mencionados tendo como objeto o discurso dos LDINs publicados a partir do ano de 2000 pois, como mencionamos no capítulo 1, são os que possuem textos, e não só estruturas gramaticais que teriam o propósito de praticar a língua enquanto ferramenta para situações previsíveis. Foi principalmente a partir da transposição de textos sobre as diversas culturas para os livros didáticos aqui analisados que houve acesso a um conhecimento sócio-culturalideológico. $O$ ensino de inglês para fins específicos, na sua fase inicial, como 
vimos no capítulo 1, focado em situações comunicativas previsíveis (palavras ou expressões para atender ao telefone ou conduzir uma reunião, por exemplo), e não cedia espaço a temas voltados para as representações de culturas. Porém, desde a última década, houve a inserção de conteúdo voltado a modos de lidar com aspectos sócio-culturais e ideológicos de outros países, ou seja, do outro. Se em sua fase inicial o LDIN focava no 'como' fazer negócios a partir de um enfoque técnico- comunicacional, num segundo momento esse 'como' se mantém, porém engloba o âmbito sócio-cultural ideológico, equiparando-se a um guia cultural.

Para FOUCAULT (1971: 44) 'todo sistema de educação é uma maneira política de manter ou de modificar a apropriação dos discursos, com os saberes e os poderes que eles trazem consigo'. Refletindo sobre a mudança de foco nos LDINs descrita anteriormente, verificamos que eles constituem uma materialidade lingüística que manteve, mas também modificou, a apropriação do discurso do livro didático de inglês para negócios. Ao continuarem funcionando como parâmetros e opções amplamente utilizados nos dias atuais como material de ensino destinado a este fim, mantiveram-se como o discurso da verdade. Contudo, ao representarem, em seu conteúdo, as culturas a partir das perspectivas econômica, política e social, modificaram o tipo de conhecimento trabalhado: não mais estruturas gramaticais ou expressões situacionais, mas considerações voltadas ao âmbito cultural.

A seguir, faremos a contraposição de seu funcionamento com a questão da participação dos alunos na construção desse conhecimento sobre as culturas, já que o discurso da sala de aula os constitui enquanto sujeitos de um saber. Podemos afirmar que há, pelo menos, três formas pelas quais o LDIN instaura um discurso de verdade. $\mathrm{Na}$ seção seguinte, faremos $\mathrm{O}$ questionamento sobre as mesmas.

\section{1- A 'autenticidade' como discurso verdadeiro}

O discurso sobre a importância da utilização de conteúdo autêntico na sala de aula encontra respaldo tanto na esfera de políticas educacionais como na acadêmica. Como exemplo da primeira, o Common European Framework of 
Reference for Languages $^{26}$ consiste em um conjunto de diretrizes que estabelece parâmetros didático-pedagógicos para o ensino de línguas estrangeiras na Europa. Segundo sua própria definição, é um guia sobre o quê e como os alunos devem aprender uma língua, e que inclui tanto conhecimentos linguísticos como habilidades a serem desenvolvidos para que os alunos estejam aptos a agir efetivamente. Entre vários pontos em sua ementa, é previsto que um aprendiz de língua estrangeira precisa realizar algumas ações, como por exemplo: ter direta exposição à língua estrangeira (face a face com nativos, ao ouvir o rádio ou ver a TV, utilizar CD ROMs), ter participação direta em interações comunicativas autênticas com um interlocutor competente, entre outras. Assim, percebemos a presença do 'autêntico' como princípio norteador para a efetividade do aprendizado. O discurso do 'Common European Language Framework', assim, legitima o discurso dito 'autêntico' utilizado nos livros didáticos e no discurso da sala de aula sobre o ensino da língua inglesa.

Um dos livros analisados nesta pesquisa diz ser produzido de acordo com parâmetros dessa ementa:

'Business Start Up 1 covers competencies from level A1 of the Common European Framework of Reference for Languages and leads into A2. Business Start Up 2 covers competencies from A2 and leads into B1. ${ }^{27}$

$\mathrm{Na}$ esfera acadêmica, ancorada nos princípios da linguística aplicada, a visão de 'material autêntico' é bastante aceita, pois acredita-se que uma aprendizagem ideal é aquela que proporciona um contato direto com os falantes do idioma, ou, na falta deste, acesso a materiais produzidos para os mesmos. Em seu artigo, CARVALHO (1993: 118) ${ }^{28}$ elenca alguns autores ${ }^{29}$,

\footnotetext{
${ }^{26}$ Facilmente disponível para download na Internet.

${ }^{27}$ As siglas $\mathrm{A} 1, \mathrm{~A} 2$, B1 e $\mathrm{B} 2$ referem-se à divisão de níveis pressuposta no Common European Language Framework. A letra ' $A$ ' refere-se ao nível comumente chamado de 'básico' e referido na ementa como 'basic user', 'B' ao 'intermediário', referido na mesma como 'independent user'.

${ }^{28}$ Disponível em <http://repositorium.sdum.uminho.pt/bitstream/1822/518/1/1993\%2c6\%282\%29\%2c117124\%28AnaAmeliaAmorimCarvalho\%29.pdf>
} 
abaixo mencionados, que compartilham da ideia não só do que seja material autêntico, mas também de sua importância na aprendizagem de uma língua estrangeira. Para ROGERS e MEDLEY (1988), material autêntico é aquele que reflete um contexto situacional e cultural próprios e, para que os alunos possam aprender a comunicar-se numa língua estrangeira, devem ter um contato tão direto quanto possível com ela, ouvir e ver os nativos a utilizá-la com uma finalidade comunicativa. Na impossibilidade de se deslocarem ao país, o uso de materiais autênticos torna-se pertinente na aprendizagem (WILKINS, 1976; KIENBAUM et al., 1986; ROGERS e MEDLEY, 1988; BERWALD, 1986). Para este último, material autêntico é todo material que não foi adaptado, simplificado e criado para ser ensinado a alunos de línguas, mas aquele escrito ou gravado para um público comum e não particularmente para alunos, ideia também compartilhada por KIENBAUM (KIENBAUM et al, 1986).

Notamos que, nas definições acima, o elemento 'autêntico' está quase que exclusivamente relacionado à produção para falantes nativos, e que para servir como material para uso na sala de aula não deve ser adaptado ou alterado.

Faremos um paralelo entre as perspectivas anteriormente descritas sobre material autêntico, e aos sentidos do termo 'autenticidade' segundo o que se apresenta no LDIN. Verificaremos que, através de pelo menos três formas, são produzidos sentidos para esse termo por meio de discursos legitimados, que apagam a historicidade e dão a ilusão de que o sentido é único e que advém de uma fonte única. Passemos, então, à análise do corpus.

Desde uma década, aproximadamente, são bastante presentes, no conteúdo dos LDINs, artigos e exercícios de áudio caracterizados pelo LDIN como 'autênticos'. Teoricamente, e segundo o que postula o LDIN, a presença de material autêntico garante um conteúdo que traz o real dos fatos do mundo

\footnotetext{
${ }^{29}$ As referências completas dos autores mencionados por CARVALHO (1993) encontram-se na bibliografia.
} 
dos negócios. Vejamos exemplos da questão da autenticidade em três manuais do professor:

\section{Excerto 4}

The Reading texts in In Company Elementary have been chosen to involve, entertain and provoke students as well as to contextualise key target vocabulary. They are all based on authentic items taken from the press and Internet, but have been adapted to make them more accessible to learners at this level. ${ }^{30}$

No excerto 4, há a afirmação de que o conteúdo do LDIN baseia-se em conteúdo autêntico, ou seja, parte dele, mas não é fiel a ele, pois 'os textos são adaptados para que sejam mais acessíveis aos alunos neste nível'. Ou seja, não é possível afirmar que os textos utilizados nos LDINs sejam autênticos, se tomarmos como definição para 'autêntico' textos que não foram modificados. Portanto, nesse excerto, 'material autêntico', no sentido segundo as esferas política e acadêmica anteriormente delimitadas, é utilizado apenas como base para a produção do discurso do LDIN. Vejamos o próximo excerto:

\section{Excerto 5}

One of the principles is that students should deal with as much authentic content as their language level allows. Authentic reading and listening texts are motivating for students and bring the real world of business into the classroom, increasing students' knowledge of business practice and concepts. Due to its international coverage the Financial Times has been a rich source of text and business information for the course. ${ }^{31}$

No excerto 5, o sentido de material autêntico modifica-se: não há menção à adaptação, mas é afirmado que há utilização de material autêntico: '[...] students should deal with as much authentic content as their language level

\footnotetext{
${ }^{30}$ In Company Elementary. Teacher's book. 2005, p. 6.

${ }^{31}$ Market Leader Upper intermediate Business English Teacher's book. 2006, p. 4.
} 
allows. Authentic reading and listening texts are motivating for students and bring the real world of business into the classroom'.

Encontramos uma justificativa no LDIN para a utilização de material autêntico: 'Due to its international coverage, the FT has been a rich source of text and business information for the course'. Ou seja, o sentido que se fixa é que a extensa abrangência do jornal basta para garanti-lo como fonte confiável e, portanto, adequada ao ensino de inglês para negócios.

Para GREGOLIN (2003: 96) "A mídia produz sentido por meio de um insistente retorno de figuras, de sínteses-narrativas, de representações que constituem o imaginário social". O discurso da mídia interfere, portanto, na formação do imaginário dos sujeitos do discurso da sala de aula (alunos e professores), funcionando como parâmetro do que seja correto.

A mídia consiste numa prática social e constitui outras, pois, no mundo de hoje, serve como parâmetro quase que exclusivo de representação destas. Ao veicular fatos sociais, atribui-lhes sentidos que se tornam verdades absolutas e incontestáveis.

Já um outro sentido atribuído à autenticidade refere-se a dizeres de especialistas em diferentes áreas de conhecimento:

Excerto 6:

The authentic listening texts are based on interviews with business people and experts in their field. Students develop their listening skills such as prediction, listening for specific information and note-taking. ${ }^{32}$

'Autêntico' passa a significar, então, conteúdo baseado em textos (de entrevistas, por exemplo) de conhecedores de áreas específicas ou especialistas ("business people and experts in their field"), ou seja, discursos sobre conhecimentos científicos. Portanto, com relação a alguns tipos de atividades do LDIN, a característica 'autêntico' remete a falas e considerações de pessoas especialistas nos assuntos tratados.

Uma terceira forma de autenticidade se baseia na voz popular como base para os exercícios de 'listening', no excerto 7.

\footnotetext{
${ }^{32}$ Market Leader Intermediate. Business English Teacher's Resource Book. 2006, p. 4.
} 


\section{Excerto 7}

As well as the usual dialogues and narrative extracts, vox populi -ordinary people's views on a particular topic -is a characteristic feature of the recordings. These have been scripted for the sake of clarity, but they do help students in small classes and one-to-one -it's easier to articulate your views when there are other views to support or differ from. The recordings feature both native and non native speaker accents, providing students with extensive exposure to real spoken English. ${ }^{33}$

A presença da voz do povo, portanto, também constitui-se como uma das formas de autenticidade. Ainda há a informação de que as gravações contemplarão tanto a fala de nativos como de não nativos.

No excerto 8, reproduzido a seguir, percebemos a questão da naturalidade (grifo nosso) como fator motivador e necessário como parte de um discurso autêntico (já que este tem que visar trazer o 'mundo real'), de modo que uma língua ideal só o é se refletir ('mirror') a língua tal como é falada hoje (apesar dos limites impostos pelo nível do livro ${ }^{34}$ e vocabulário), porque afirmase que é assim que os alunos sentem-se motivados (afirmação que também consta no excerto 5):

\section{Excerto 8}

The listening material in Business Start Up is designed to mirror natural English, as it is spoken today, despite the obvious constraints of level and vocabulary. Great care has been taken to provide natural, realistic-sounding texts to motivate students and prepare them for the type of language they'll find in the real world. Both teachers and students will find the listening material refreshing, stimulating and motivating. ${ }^{35}$

Identificamos, portanto, pelo menos três formas para o sentido de 'autenticidade' e cada uma define-se a partir de uma materialidade que produz

\footnotetext{
${ }^{33}$ In Company Intermediate. Teacher's Book. 2002, p. 6.

${ }^{34}$ O nível refere-se às divisões da série do livro ao longo do curso, em 'básico', 'pré- intermediário', 'intermediário', 'pós-intermediário' e 'avançado'.

${ }^{35}$ Business Start Up 2. Teacher's Book. p. 5.
} 
discursos vistos como verdadeiros e aceitáveis. No excertos 4 e 5 , é a mídia que constitui o sentido de autenticidade; já nos excertos 6 e 7, respectivamente, profissionais (pessoas de negócios ou especialistas) e pessoas anônimas (Vox Populi) que integram o que se entende por autêntico.

Ser 'autêntico' funciona como evidência. O LDIN afirma que suas formulações são 'autênticas' (o discurso da mídia, o dos especialistas e o das pessoas anônimas -incluindo falantes nativos da língua), e estas, mesmo que contraditórias $^{36}$ funcionam como transparências. São estabilizadas pela categoria 'autêntico' e funcionam livremente: produzindo sentidos considerados adequados.

É nesse sentido que podemos afirmar, baseando-nos em PÊCHEUX (1975: 146), que:

É a ideologia que fornece as evidências que fazem com que uma palavra ou enunciado "queiram dizer o que realmente dizem" e que mascaram, assim, "sob a transparência da linguagem", aquilo que chamamos o caráter material do sentido das palavras e dos enunciados ${ }^{37}$.

Essa evidência ocorre por um funcionamento discursivo específico. Ao afirmar que seu discurso é autêntico, o LDIN se coloca numa posição de origem de um dizer apropriado (porque real) e produz a impressão de ser a única forma de conteúdo válido.

Sobre esses efeitos, o autor (op. cit., p. 161 et seq) afirma que o 'fazer sentido' se dá a partir de dois 'esquecimentos': o esquecimento número 1, que é da ordem do sujeito e implica o fato de que este acredita ser a origem do dizer. Já o 2, da ordem da enunciação, acontece quando acreditamos que o que dissemos só poderia ter sido dito daquela forma, e não de outra.

Essa evidência é apenas ilusória, pois o sujeito está inserido na formação discursiva que o constitui e, assim, não percebe que é assujeitado:

O próprio de toda formação discursiva é dissimular, na transparência do sentido que nela se forma, a objetividade material contraditória do

\footnotetext{
${ }^{36}$ O discurso Vox populi é, por definição, a voz do senso comum, sem validação científica. Já o discurso dos especialistas são do tipo legitimado institucionalmente.

${ }^{37}$ Nesta citação, a palavra 'enunciado' equivale a 'formulação', da ordem da frase. Já no capítulo 3, o termo 'enunciado' será utilizado segundo o que postula Foucault (1969) -discutido por Deleuze (1988)-, para quem o enunciado é da ordem do repetível e não da frase.
} 
interdiscurso, que determina essa formação discursiva como tal, objetividade material essa que reside no fato de que "algo fala" (ça parle) sempre "antes, em outro lugar e independentemente", isto é, sob a dominação do complexo das formações ideológicas. (idem, op. cit., p. 149).

Assim, pela evidência, tem-se e trabalha-se o 'naturalmente verdadeiro' dos discursos de forma que a validade desse discurso já está pressuposta.

ORLANDI (1999: 46) afirma que 'a evidência do sujeito apaga o fato de que o indivíduo é interpelado em sujeito pela ideologia'. A transparência que se forma a partir de material autêntico esconde a sua materialidade e o sujeito esquece que o sentido não se forma ali, mas aquém, $O$ precedendo, ideologicamente e inevitavelmente. A questão é que o uso de material denominado 'autêntico' naturaliza sentidos e, por isso, satisfaz as exigências da sala de aula, uma vez que esta precisa trazer discursos tidos como comprometidos com a informação real. O discurso denominado 'autêntico', em sua suposta transparência, traz o real dos fatos, como mostram os excertos $5 \mathrm{e}$ 8, com a expressão 'real world'. O sentido correto e, portanto, a verdade, são criados no momento em que a autenticidade aparece como evidência e produz seus efeitos.

Foucault, ao tratar das regras próprias ao discurso, afirma que uma delas é a da exterioridade, que nos diz que devemos passar do discurso para as suas condições externas de possibilidade, e não tentar ir em busca de seu interior ou seu núcleo para descobrir-lhe o segredo. É o exterior que Ihe fixa barreiras, delimita suas fronteiras, ou seja, que o constitui:

[...] parece-me que existem, na sociedade, ou pelo menos, em nossas
sociedades, vários lugares onde a verdade se forma, onde um certo
número de regras de jogo são definidas -regras de jogo a partir das
quais vemos nascer certas formas de subjetividade, certos domínios
de objeto, certos tipos de saber -e por conseguinte podemos, a partir
daí, fazer uma história externa, exterior, da verdade. (FOUCAULT,
2005: 11)

O que ele afirma é que 'são criadas regras do jogo fora do jogo': antes de ser jogado, este já possui regras. No momento do jogo, as regras são verdades, evidências, portanto.

O discurso 'autêntico' pressupõe trazer o 'real do mundo', ou seja, o que traduz os acontecimentos do mundo. E afirma que esse conteúdo é mais apropriado que os outros. CORACINI (1991: 71) afirma que a tentativa de 
cercear a criatividade, no plano da expressão lingüística mostra, por parte da comunidade científica, uma tendência ao estabelecimento de uma relação direta entre a expressão lingüística e os fatos reais, postulando o princípio da 'transparência da linguagem'. Ainda acrescenta:

O fato de não se conhecerem as experiências senão através da expressão lingüística em artigos que se apresentam sempre numa dada organização linear, leva a crer na linearidade dos processos (de investigação e de redação) constitutivos do discurso.

As 'sínteses acabadas' a que Foucault se refere e que mencionamos anteriormente são categorias discursivas sobre as quais geralmente não nos questionamos enquanto sujeitos, mas que produzem efeitos evidentes, por pressuporem uma coerência e uma ligação com a verdade, que aqui constituem-se nas implicações do que seja 'autêntico', discutidas a seguir.

O que a questão da autenticidade implica, em um primeiro momento, é que os textos, por partirem de jornais ou revistas de grande cobertura internacional, ou seja, de discursos legitimados para a circulação, correspondam a uma verdade e, antes disso, que existe uma verdade a ser transmitida e compartilhada. Assim, o discurso 'autêntico' ilustra os dois esquecimentos de Pêcheux, pois a mídia e as vozes das pessoas (os discursos considerados autênticos) são vistas como a origem única do discurso e como a verdade deste.

Os sentidos de autêntico e seu efeito enquanto linearidade levam-nos a uma constatação e a um questionamento: apesar de estarmos diante de sentidos contraditórios com relação ao que seria um discurso apropriado no LDIN: material adaptado e material não-adaptado (sem alterações), vozes de especialistas, Vox Populi, esses discursos são considerados um bloco homogêneo. O questionamento é: enquanto sujeito aluno, como este é constituído neste entrecruzamento de discursos?

Aos sujeitos da sala de aula, principalmente ao aluno (enquanto sujeito de um saber), o que fica silenciado é que são jornais ou revistas ingleses, ou seja, estão circunscritos a essa região específica (que não constitui-se numa unidade) e trazem a informação a partir da visão britânica (que também não é homogênea) dos conteúdos veiculados. Via mídia britânica, o sujeito- aluno é constituído por um discurso que embora se denomine homogêneo, não o é, já que apaga a característica de restringir-se a pontos de vista específicos. 
Sentidos evidentes são mesmo esperados pelo discurso jornalístico. Nas palavras de CARMAGNANI (2003: 114), 'O discurso jornalístico visa persuadir o leitor de que aquela, a visão do jornal, é a versão que retrata a realidade e a verdade'.

Acreditamos que a questão da autenticidade constitui-se como um dos pontos sobre os quais o LDIN se apóia no sentido de resguardar uma interpretação ou evitar que aquela produzida pelo livro seja questionada e potencialmente refutada e, assim, 'o silêncio trabalha os limites das formações discursivas, determinando consequentemente os limites do dizer' (ORLANDI, 2007: 74). O material autêntico, assim, passa a ser evidência de sentido. Temos, aqui, o silêncio da origem. Esta não existe, mas ao precisar existir enquanto positividade, encontra-se no conforto da legitimação institucional e, consequentemente, social.

Em um segundo momento, faz-se necessário discutir a questão da adaptação: ao mesmo tempo em que o LDIN afirma ter um conteúdo autêntico, também afirma que o adapta para que fique compatível com o conhecimento lingüístico dos alunos. Ou seja, se a definição de material autêntico no início desta seção implica uma não-alteração na notícia e o LDIN afirma que produz modificações, então o material inserido no LDIN já não é mais autêntico. $E$ mesmo que a noção de material autêntico para o LDIN diferisse daquela segundo a visão acadêmica e do âmbito político-educacional, não há um sentido único para ela, o que sucumbe o próprio projeto de trabalhar com autêntico enquanto linearidade e unicidade.

$\mathrm{Na}$ próxima seção, trabalharemos as vozes identificadas nesta seção, procurando compreender de que maneira elas homogeneízam o discurso do LDIN.

\section{2- A homogeneização das vozes}

Na seção anterior, constatamos que a mídia, os especialistas e a voz popular procuram formar, discursivamente, uma unidade que, sob a caracterização de 'discurso autêntico', produz sentidos para os discursos no LDIN, fazendo com que este seja visto como estando no 'verdadeiro' e que, por isso, corresponde ao discurso mais apropriado para se trabalhar na sala de 
aula. Verificamos que há, portanto, três sentidos através dos quais a autenticidade se constitui, que são representados por três tipos de vozes diferentes.

No imaginário, essa pluralidade de opiniões, à primeira vista, significa um espaço reservado a diferentes pontos de vista, a partir de um discurso tido como universal e abrangente. Entretanto, discutiremos como o LDIN produz um discurso homogeneizante por meio da heterogeneidade de seu discurso, ou seja, da presença do outro ou do discurso do outro, buscando responder à questão: o outro representa de fato uma outra voz, ou uma mesma voz?

Tomamos como ponto teórico de partida a concepção da natureza heterogênea da linguagem, que se baseia no fato de que esta não se fecha em si mesma, mas é produzida pelo outro do discurso, pelo seu exterior e como várias vozes ressoam numa só, produzindo efeitos de sentidos estáveis e naturalizados.

A questão da não-unicidade ou da natureza constitutivamente dialógica da linguagem não foi preocupação considerada primeiramente pela AD. Preocupado com a busca de como o sentido é construído ou instaurado, o filósofo russo BAKHTIN (1973: 102), já afirmava que 'qualquer entendimento verdadeiro é dialógico por natureza', antecipando a questão do caráter material do sentido por si mesmo, ou seja, como não fechado em si mesmo, mas referindo-se a outros e fazendo sentido a partir deles. Segundo AUTHIERREVUZ (2004: 46):

[...] esse outro do dialogismo de Bakhtin não é nem o objeto exterior do discurso (falar do discurso do outro), nem o duplo, não menos exterior do locutor: ele é condição do discurso, e é uma fronteira interior, que marca no discurso a relação constitutiva com o outro. (grifo nosso)

Para Bakhtin, todo discurso é dialógico, uma vez que é produzido no contexto dos discursos que o precederam e os que virão depois: é a partir de outros discursos que ele adquire seu sentido.

O dialogismo diz respeito ao permanente diálogo, nem sempre simétrico e harmonioso, existente entre os diferentes discursos que configuram uma comunidade, uma cultura, uma sociedade. É nesse sentido que podemos interpretar o dialogismo como o elemento que instaura a constitutiva natureza interdiscursiva da linguagem. (BRAIT, 2005: 94 et seq) 
Embora a AD de Pêcheux não trate do conceito 'dialogismo', pressupõeno, pois postula a não-unicidade de um texto, ou seja, a constituição de um discurso a partir do discurso do outro, que é basilar para a noção de discurso na $A D$ : um texto não é uma soma de palavras que têm seu sentido determinado a partir de si mesmas, ou seja, os sentidos não estão nas palavras, a linguagem não é transparente, mas seu sentido se forma a partir de outros discursos, o que constitui a heterogeneidade. Nas palavras de ORLANDI (1999: 39):

Segundo a relação dos sentidos, não há discurso que não se relacione com outros. Em outras palavras, os sentidos resultam de relações: um discurso aponta para outros que o sustentam, assim como para dizeres futuros. [...] Um dizer tem relação com outros dizeres realizados, imaginados ou possíveis.

Assim, os sentidos se relacionam com outros, que o precederam, mas que vêm depois, mas também com aqueles imaginados ou possíveis. Não há, portanto, um dizer cujo sentido se encerre na instância do significante. Essa característica dos discursos constitui-se na heterogeneidade.

Partiremos da noção de heterogeneidade segundo o que postula AUTHIER-REVUZ (2004). Segundo a autora, há duas formas de presença do outro no discurso. Uma forma é explicitamente marcada, pela presença do outro no fio do discurso ou pontos em que a heterogeneidade aflora no dizer, como por exemplo, na forma de citações ou uso de aspas - é a chamada heterogeneidade mostrada, de que trataremos na seção 2.2.2.

Outra forma da heterogeneidade se dá constitutivamente, que embora não apareça delimitada no discurso por meio de marcas lingüísticas, está presente, em toda sua extensão, caracterizando a presença do interdiscurso. É no capítulo 3 que discutiremos essa forma de heterogeneidade.

Apoiaremo-nos também, para a análise, e em complemento ao postulado de Authier-Revuz, em GUIMARÃES (2005), no que se refere à questão das vozes, ou seja, quem fala, no discurso. Segundo o autor, (op. cit:: p. 23), o Locutor (L) é aquele a quem é imputada a responsabilidade do dizer: "L é então o lugar que se representa no próprio dizer como fonte deste dizer". Acrescenta ainda que '[...] para o Locutor se representar como origem do que 
enuncia, é preciso que ele não seja ele próprio, mas um lugar social de locutor', ou seja, é preciso estar afetado pelos lugares sociais autorizados a falar. Esse lugar social do locutor é o locutor-x, que é variável, podendo ser um presidente, um diretor de uma empresa, um professor, entre outros.

Como vimos na seção anterior, a voz dos jornalistas, via mídia, constituise como a principal fonte de conteúdo do LDIN, uma vez que a ela são creditadas credibilidade e imparcialidade na informação. Assim, ao assumir os dizeres, caracteriza-se como a origem das formulações, sendo, assim, o que podemos chamar de principal Locutor no LDIN. Os lugares sociais de locutores, ou seja, os enunciadores são, geralmente, locutores-jornalistas, locutoresespecialistas, locutores Vox Populi, que são as vozes que constituem o discurso no LDIN.

Nosso objetivo, nas seções seguintes, é articular a noção de heterogeneidade (a condição discursiva da presença do outro) no discurso no LDIN, ou seja, analisar a voz do outro nesta materialidade e seus efeitos de sentido.

\subsection{1- A inclusão pronominal do interlocutor e seu funcionamento}

Os textos desta seção trazem conteúdo a partir da articulação de noções sobre temas gerais próprios da área de negócios; nos casos que analisaremos, a globalização e o uso de websites corporativos. Porém, verificaremos como formas de inscrição do discurso do outro particularizam esses textos.

Como um primeiro exemplo, temos excertos de um artigo (artigo A) que questiona os efeitos da globalização. $O$ artigo ${ }^{38}$ e exemplifica a produção de efeitos de sentido a partir da presença do outro no discurso do LDIN, conforme discutimos a seguir:

\footnotetext{
${ }^{38}$ Market Leader Intermediate. Teacher's Resource Book. 2002, p. 164.
} 
A referência ao nome do jornalista ('by Richard Tomkins') é feita logo acima do primeiro parágrafo, juntamente com o nome do jornal (Financial Times), que aparece na instrução do artigo ('Read this article from the Financial Times and answer the questions'). Não há indicações de data de publicação do artigo. Como percebemos no anexo, a presença das margens em volta do texto causa a impressão de que ele foi retirado do jornal sem que se tenham feitas alterações. Vejamos o Artigo A:

\section{Globalisation needs no defence - it needs to be questioned}

\section{by Richard Tomkins}

The main point of the globalisation argument is tha trade liberalisation drives economic growth and economic 5 growth raises living standards. It supporters say that on a wide range of measures - poverty, the age to which people live, health, education - more, people have 10 become richer at a faster pace in the past 60 years than ever before. However, globalisation's opponents would claim that this success has had its negative sides: 15 that the increases in prosperity have favoured the rich far more than the poor, that trade liberalisation has encouraged the growth of bad working conditions 20 and child labour, that lifting the barriers to the free flow of international capital has increased financial instability, and so on.

25 Globalisation's enthusiasts are so good at cataloguing globalisation's benefits while ignoring its costs. And I am referring not just to the flight of

30 jobs from developed countries to less developed ones or the environmental damage caused by the developing world's rapid industrialisation, but to globalisation's social and cultural effects.

After all, for those of us in the developed world, there is hardly a part of our lives that globalisation has not touched. On the plus side, for example, it has greatly increased consumer choice Britons can now buy strawberries all year round from their local supermarket, drive a Czech-built Skoda, wear trainers made in Vietnam and spend their holidays in China. But while their power as consumers may have grown, their power as employees has probably diminished as globalisation has increased competition and work pressures, and heightened job insecurity.

What I would like to see, therefore, is an attempt to weigh up the costs and benefits of globalisation to decide whether, on balance, it is making the world a better place or a worse one - not just economically, but across a range of issues. Economically, it could start by asking whether globalisation is a good thing because it offers the hope of lifting millions out of poverty, or whether it is a bad thing because, as is often claimed, it is widening the gap between rich and poor. It would also have to ask whether the drive to increase living standards through ever-greater levels of industrialisation and consumption was making unsustainable demands on the earth's resources.

Personally, however, I would be more interested in reading its cost/benefit analysis of the social and cultural questions. Does globalisation, for example, increase our access to the arts, or are we suffering from a global pop culture easily sold everywhere?

85 Does globalisation enable more people to experience the surprises and pleasures of cultural diversity or is it leading to the elimination of differences and the mixing of national and local cultures into a global, mainly American, stew? Are our lives made more interesting and exciting by grobalisation's destruction of old traditions and communities or are we made more miserable by the loss of the cultural individuality that gives structure to our lives?

From the Financial Times

O texto inicia-se em terceira pessoa, com um tom explicativo- descritivo, sem uso de pronomes pessoais, 'The main point of the globalization argument is that trade liberalisation drives economic growth and economic growth raises living standards', porém, somente até a linha 28 , quando aparece a voz do locutor-jornalista, que expressa sua opinião, 'And $\underline{I}$ am referring not just to the flight of jobs from developed countries to less developed ones or the environmental damage caused by the developing world's rapid industrialization, but to globalisation's social and cultural effects.' Há outros trechos em que aparece o pronome ' $I$ ', como na linha 55, em 'What I would like to see, 
therefore, is an attempt to weigh up the costs and benefits of globalisation to decide whether, on balance, it is making the world a better place or a worse one -not just economically, but across a range of issues' e na linha 77, 'Personally, however, 1 would be more interested in reading its cost/benefits analysis of the social and cultural questions'. São trechos que, pronominalmente, se referem ao locutor-jornalista.

Sua voz reaparece na linha 37, porém, na forma 'us' ('After all, for those of us in the developed world'). Esse mesmo 'l', portanto, desliza para 'us'. Ou seja, o pronome 'us', se considerada a sentença em que primeiro aparece, refere-se às pessoas dos países desenvolvidos, como nas linhas 37, cujo referente pode ser o mesmo do das linhas 41 a 45: os britânicos ('it has greatly increased consumer choice: Britons can now buy strawberries all year around from their local supermarket'). Porém, na linha 82 tem-se o pronome 'our' ('Does globalization, for example, increase our access to the arts or are we suffering from a global pop culture easily sold everywhere?') e nas linhas $92 \mathrm{e}$ 97, ('Are our lives made more interesting and exciting by globalisation's destruction of old traditions and communities or are we made more miserable by the loss of cultural individuality that gives structure to our lives?') os pronomes 'our' e 'we' parecem não mais representar somente a voz dos britânicos (incluindo o jornalista), mas também a dos interlocutores do texto, ou seja, a instância da segunda pessoa, por meio do pronome 'you'. Ou seja, inclui-se a voz do(s) interlocutor(es) naquela do locutor. CORACINI (2003: 325) afirma que nesse caso ocorre a incorporação da intersubjetividade e 0 interlocutor se vê obrigado acuar-se diante do que está sendo formulado, restando a ele pouca ou nenhuma escolha a não ser concordar com a perspectiva do enunciador.

O uso do pronome 'l' é uma posição-sujeito inicial que abre espaço para outras, sub-repticiamente, funcionando, em um primeiro momento, como 'portavoz' da opinião do locutor-jornalista, e em dois outros momentos: um segundo, em que fala em nome dos países desenvolvidos, representado pelos britânicos, e um terceiro, em que sugere a inclusão da posição-sujeito interlocutor. $O$ interlocutor é, assim, interpelado e inscrito na instância da enunciação. 
Em texto que trata das marcas subjetivas no discurso, BRANDÃO (1998: 144) mostra que a utilização do pronome de primeira pessoa 'nosso' provoca uma reação emotiva no destinatário, ao interpelar o seu sentimento de pátria, de nacionalismo, fazendo-o identificar-se e solidarizar-se com a coletividade, criando um efeito de verdade. Além disso, o locutor, para falar de si mesmo, avança os limites de suas fronteiras, 'invadindo polifonicamente as diferentes instâncias interlocutoras' (idem, op. cit., p. 58).

Ou seja, a voz (de autoridade) do jornalista se mescla com a voz de outras pessoas, de modo que sua voz se torna porta-voz dessas outras. Esse englobamento pronominal (e semântico), ou seja, o pronome 'you' (representado pelos interlocutores), ao fazer parte da abrangência de 'we', não é percebida pelo interlocutor. Este é incluído no discurso, afinal, 'we' pressupõe 'l' + 'you' e esse 'you' pode ser 'você' ou 'vocês'. Ou seja, o leitor é interpelado, mas essa interpelação é apagada ideologicamente. O pronome 'nós' pode ser caracterizado como inclusivo, por ter o interlocutor pressuposto, mas também excludente, pois exclui o outro (país não desenvolvido) de seu discurso, a despeito de uma voz globalizante.

Em outro artigo da mesma coleção de livros, intitulado 'Now, about this web thing ${ }^{39}$ (Artigo B) encontramos novamente a presença do pronome 'l'. O artigo refere-se ao valor da comunicação em websites corporativos ${ }^{40}$.

No artigo, o locutor-jornalista se aproxima do leitor de duas formas: numa primeira, a sua voz se faz presente explicitamente pelo uso do pronome de primeira pessoa, apresentando seu ponto de vista. Para justificar gastos com a comunicação corporativa, o 'l' introduz-se como um sujeito argumentativo que sustenta uma formulação, no caso, o porquê de se gastar mais dinheiro com o site da empresa:

\footnotetext{
${ }^{39} \mathrm{O}$ artigo, na íntegra, encontra-se no anexo.

${ }^{40}$ Market Leader Upper Intermediate Business English Teacher's Book. 2006. p. 134
} 
Your corporate website is an investment that is quite likely the biggest element in your communications budget; whose Return on

5 Investment (ROI) you cannot measure; and whose benefits are difficult to describe. And now I would like to explain why you should be spending more on it.

Além disso, o uso do modal deôntico 'should' em 'Now I would like to explain why you should be spending more on it', suaviza o tom autoritário de que é provida a formulação, escondendo seu caráter impositivo. CORACINI (2003: 325) afirma que 'o uso dos verbos modais camufla o tom autoritário subjacente, apresentando o que é dito como uma necessidade natural, intrínseca à realidade ou ao processo de que se fala'. Ou seja, no excerto acima, 'gastar mais com websites faz-se necessário'.

De uma outra forma, o locutor estabelece uma relação próxima com o interlocutor, ao fazer uma pergunta-confirmação, na qual o locutor antecipa a expectativa do interlocutor 'you don't want to upset them, do you?':

\footnotetext{
Third, your investor relations team would get irate phone calls from analysts looking for an elu- 7 sive figure from the 1999 annual report. Analysts are used to finding historical data on company sites, and you don't want to upset them, do you?
}

Aqui, o interlocutor se vê interpelado a concordar com o jornalista. No ultimo parágrafo, ordena diretamente através dos imperativos:

But of course this is going to cost money in the short term. So when your corporate affairs director asks you to approve a project with no apparent ROI, please don't laugh in his face. Ask your fellow CEOs instead; I bet they are getting very similar requests.

A expressão 'please don't laugh in his face' é seguida de uma outra forma imperativa, 'Ask you fellow CEO instead', e de uma aposta ('I bet they are getting very much similar interests'). Fica estabelecido, assim, um vínculo, ou seja, uma proximidade, entre o locutor e o interlocutor. O uso da modalidade lógica 'of course' em 'of course this is going to cost money' também reforça o sentido de verdade do texto. CORACINI (2003: 325) afirma que esse tipo de 
modalidade funciona como uma conclusão lógica, reforçando o efeito de irrefutabilidade, pela incorporação da intersubjetividade. Esse tipo de modalidade produz sentido por constituir-se num argumento de autoridade, 'ao mesmo tempo em que tem a capacidade de acuar o interlocutor, colocando-o diante da obrigação de saber que todo texto tem uma lógica'.

Os artigos analisados reflexões acerca de temas que podem ser utilizados para várias ocasiões. Nos artigos analisados, verificamos que a maioria dos textos encontrados no LDIN não apresentam elementos próprios do discurso jornalístico-informativo (a lide, que corresponde a 'o que' aconteceu, 'onde' e 'quando'); além disso, há diversos elementos subjetivos presentes nas formulações. Discutimos que, explicitamente, o enunciadorjornalista aparece, no primeiro excerto, por meio do pronome 'l' que desliza para 'us'; no segundo, com a presença do 'l' novamente, porém de maneira diferente, ao colocar para o interlocutor ordens, através de formulações no imperativo e o interpelar a uma resposta específica: a de concordar com o enunciador.

Porém, ainda assim, ocorre o silenciamento da presença subjetiva e colocam-se no leitor 'lentes de objetividade', ao fazer com que este leia o 'artigo' de uma certa forma e não outra, camuflando, no momento da leitura, os elementos que atestam a subjetividade no texto.

Na próxima seção trataremos de textos em que a opinião prevalece.

\subsection{2- Texto opinativo- presença do autor a partir de juízo de valor}

Um outro modo de presença do outro acontece não mais com o uso de pronomes e/ou interpelação do interlocutor como recurso predominante, mas com a presença de discursos que privilegiam a atribuição de juízo de valor, diretamente, a acontecimentos que são assunto dos textos. São textos marcadamente mais opinativos que informativos, com o uso frequente de adjetivos e advérbios para qualificar os tópicos abordados no texto, que se diferem dos da seção anterior, já que estes privilegiam assuntos que podem ou causam polêmica. 
Embora denominados no LDIN, igualmente, de artigos, se diferem dos do tipo informativo. GRIGOLETTO (2003: 142) afirma:

Os textos opinativos, diferentemente dos textos informativos do jornal, têm legitimidade para discutir medidas, tendências e tomar partido sobre essas medidas e tendências a partir dos acontecimentos. Ou seja, aquilo que são, de fato, opiniões e pontos de vista se apresentam ora como um lugar universal de dizer e de saber submetido ao regime do verdadeiro e do falso, ora como repetição de um saber compartilhado e consensual.

Para a autora, o tipo de texto 'opinativo' constrói posições no discurso para o leitor e o que é opinião se transforma em verdades universais ou consensuais.

Os excertos a seguir são retirados de um artigo (artigo C), publicado em 9 de outubro de 2008, que trata de um livro sobre a crise financeira dos Estados Unidos. O primeiro parágrafo está reproduzido a seguir ${ }^{41}$; observe-se os trechos sublinhados:

Artigo C:

\section{One way to make sense of the present financial chaos is to look back at the past}

THE typical career of a Wall Street banker lasts about a quarter of a century, enough to span just one big financial crisis. As Niall Ferguson explains in his new book, "The Ascent of Money", which will be published next month, today's senior financiers would have started out in 1983, fully ten years after oil and gold prices first began the surge that had ruined the previous generation of money men. That, he concludes, is a "powerful justification for the study of financial history."

Mr Ferguson is right. The world needs a book that puts today's crisis into context. It is too late now to warn investors about expensive houses and financiers about cheap credit. But perhaps the past can help make sense of the wreckage of banks, brokers and hedge funds that litters the markets. Looking back may help suggest what to do next. And when the crisis is over and it is time for the great reckoning, the lessons of history should inform the arguments about what must change.

\footnotetext{
${ }^{41} \mathrm{O}$ artigo na íntegra está no anexo, mas também encontra-se disponível em http://www.pearsonlongman.com/intelligent_business/images/teachers_resourse/Pdf1.pdf
} 
No primeiro parágrafo, encontramos a remissão ao discurso de Niall Ferguson, autor escocês, que é falado pelo enunciador britânico por meio do uso das aspas, em "a powerful justification for the study of financial history". O uso das aspas pode indicar que o autor não queira se comprometer com seu conteúdo, já que verificamos a seguir sua não apreciação sobre o livro. Para AUTHIER-REVUZ (2004: 12), o locutor remete a um outro como fonte do "sentido" dos propósitos que ele relata.

O terceiro parágrafo, a seguir, contém alguns elementos (sublinhados) que mostram a opinião do enunciador:

This rushed, uneven book, by a British-born Harvard University professor who made his name a decade ago with a history of the Rothschild banking dynasty, will contribute less than expected to that debate. It has strengths, including a tidy account of the run-up in housing markets and of the symbiotic rivalry between America and China. But in the earlier chapters-the history, oddly enough, where you would expect Mr Ferguson's ambitions for his subject to quicken his judgments- the words rarely come to life, either as a source of ideas or as narrative [...]

Embora não seja pela presença de pronome de primeira pessoa, há marcas do enunciador através do uso de adjetivos ('rushed', 'uneven', 'tidy') que conferem a presença de juízo de valor. Assim, valores segundo a percepção do enunciador, são atribuídos, não caracterizando um discurso dito 'objetivo' se para tal se pressupõe, entre outras características, a ausência de pronomes de primeira pessoa. Além disso, a referência às expectativas do interlocutor com a expressão 'where you would expect Mr Ferguson's ambitions for his subject to quicken his judgments' proporciona uma aproximação do locutor-jornalista com as expectativas do interlocutor, pois aquele se coloca no lugar deste para escrever seu texto. Em outro trecho, reproduzido abaixo, o autor também opina:

It may be that Mr Ferguson was too distracted by the present to pay enough attention to the past. Claiming to be "A Financial History of the World", the book dutifully dabbles in societies, such as the Inca, who did not see gold and silver 
as money, and in the pre-Christian Mesopotamian clay tablets that served as credit notes for commodities. He traces the transformation of banchieri, named for the benches where money was changed, into the families that dominated the political and cultural life of Renaissance Italy and from there into modern bankers. He explains how the bond market had its origins in the state's need for money to finance war. He describes how manias have repeatedly engulfed greedy investors over the centuries-concentrating on John Law, whose schemes ruined 18th-century France. And he rehearses the story of financial risk from its origins in Enlightenment Scotland.

Nas duas primeiras linhas, temos o adjetivo 'too distracted' e a expressão 'dutifully dabbles in societies'. Com o adjetivo, qualifica o autor e com a expressão refere-se à maneira como este se vale das sociedades no livro como exemplo para o que se propõe a argumentar que, segundo o autor, não são comparações válidas, uma vez 'o autor distraído demais com o presente não presta atenção ao passado' e 'cautelosamente trabalha de modo superficial' as culturas; esta última constituindo-se numa ironia.

O trecho final do artigo, a seguir, qualifica a obra de forma mais direta:

Yet the reader is left wondering quite who the book is aimed at. The finance specialist will not find enough here to begin to compete with the work of Charles Kindleberger, an economic historian. And the reader who wants to know how finance is interwoven with general history would do better to turn to Jeffry Frieden's excellent 2006 work, "Global Capitalism".

No final do artigo, o autor confirma sua não apreciação do livro, primeiro ao afirmar que o público se pergunta quem seria seu público-alvo, em 'the reader is left wondering quite who the book is aimed at' e depois ao sugerir outro livro para aquele desejar saber sobre como as finanças estão interligadas com a história geral: 'Jeffry Frieden's excellent 2006 work, “Global Capitalism'.

O uso do 'você' interpela o interlocutor, ou seja, ele é instado a posicionar-se (a pensar ou refletir) no lugar do locutor, que tenta eximir-se 
enquanto produtor de sentidos (no caso, julgamentos) e ainda atribui a responsabilidade das considerações feitas sobre os temas de que trata ao interlocutor.

Outro artigo (artigo $\mathrm{D}^{42}$ ) que ilustra a interferência direta da opinião do enunciador no tema apresentado intitula-se 'On Lying', publicado em 30 de junho de 2009, na revista The Economist. A introdução à leitura do artigo é a seguinte:

\section{Before you read}

This text, On lying by Bagehot from the Economist on 30 June 2009, is about politics but it contains ideas which are also important for anyone who works in business. Bagehot is not the real name of the author, it is a pen name. It refers to Walter Bagehot (1826-1877), a famous writer about constitutions.

Em análise do excerto anterior, temos a informação de que o autor do artigo não se identifica; há algumas razões para esse fato; o autor pode não querer que seu nome seja exposto, por algum motivo. Porém, o nome divulgado refere-se ao sobrenome de um famoso compilador de constituições.

Além disso, há informação sobre as pessoas da esfera política que serão mencionadas no artigo (em negrito):

In order to understand the text, you may need some extra information about the people he mentions and some parliamentary procedures.

Gordon Brown is the Prime Minister and leader of the Labour Party. David Cameron is the leader of the Conservative Party and the Leader of the Opposition in parliament. Tony Blair was the Prime Minister before Gordon Brown. Ed Balls is one of the Ministers in the Gordon Brown Government. PMQs refers to Prime Minister's Questions, a regular weekly event in the House of Commons, when members of parliament can ask questions for the Prime Minister toanswer.

The words 'lie' and 'liar' cannot be used in the House of Commons because they areconsidered impolite.

\footnotetext{
${ }^{42} \mathrm{O}$ artigo, na íntegra, encontra-se nos anexos.
} 
A revista apresenta informações que considera necessárias para que 0 leitor compreenda de quem e de quê trata o texto. A seguir, temos a seguinte informação:

\section{On lying}

THE WORD "lie" means something very specific. It doesn't mean a misleading statement, or an exaggeration, or a half-truth: it is a falsehood advanced intentionally and knowingly. That is why, in my column last week, I wrote that probably only Tony Blair and his crew could know whether they "lied" about Iraq's weapons of mass destruction. Only they can know what was in their heads, and how far their public utterances diverged from their inner convictions. For that reason the question of lying over Iraq seems to me a bit of a red herring and distraction. What can be proved about their sloppiness and embellishments, and hasbeen, is bad enough.

O posicionamento do autor com relação ao fato se Tony Blair mentiu ou não se inicia numa coluna escrita por ele para a revista na semana anterior: 'That is why, in my column last week, I wrote that probably only Tony Blair and his crew could know whether they lied' about Iraq's weapons of mass destruction'.

Seu posicionamento através de pronome de primeira pessoa neste artigo começa quando diz '[...] the question of lying over Iraq seems to me a bit of a red herring and distraction. What can be proved about their sloppiness and embellishments, and has been, is bad enough'. Ele expõe sua opinião por meio de 'seems to me' e qualifica o que é ruim o suficiente: o que pode ser provado sobre suas negligências e 'enfeites'. O autor, então, coloca algumas perguntas a serem respondidas no artigo:

There are (at least) two big questions provoked by this revived interest in lying. First and most obviously, are Mr Brown, Mr Balls and others really and indisputably liars? Do the fiscal figures they cite and twist in any way support 
the interpretation they put on them-at least enough to make it credible that they believe what they are saying, even if no-one else does?

If so, they may not be lying. They may be over-optimistic, incompetent or deluded. But they are not obviously liars.

Aqui, temos a primeira pergunta cuja resposta depende da segunda, pois se não há números fiscais que os políticos citam e modificam que poderiam sustentar a má- interpretação que é feita sobre eles, não há como afirmarmos que eles estão mentindo. O posicionamento do autor reaparece, em 'If so, they may not be lying. They may be over-optimistic, incompetent or deluded. But they are not obviously liars'. Há, portanto, uma construção argumentativa criada pelo autor (as duas perguntas, sendo a segunda a resposta para a primeira) para que o interlocutor compreenda seu ponto de vista. A conclusão a que chega é que os políticos podem até ser os qualificados pelos três adjetivos ('over-optimistic', 'incompetent' e 'deluded'), mas não por 'liars'.

Outros momentos no artigo em que aparece o posicionamento sobre a repercussão desse tema estão destacados a seguir:

On the first: I agree that the government's selective use of figures, fondness for comparing like with unlike, switching between cash and real-terms numbers for spending, etc, are dodgy and dishonourable. That is bad enough. But are the ministers lying? It seems to me_that one potential reason to think they are not is their own self-perception. Just as medieval peasants in France could not imagine a universe without god-such an idea was not within their range of thinkable thoughts - it is possible that Mr Brown and others simply cannot countenance the scale of the hole they have helped to dig, and in particular find it hard to accept that, in the unlikely event they win the election, they will have to impose the sort of public-spending cuts they have spent their entire political careers berating. (I am trying to be charitable.) Alternatively, there may be a plan for big tax rises, as yet unannounced, that will help to substantiate their claims on spending. That would be a form of deception too, but a different one. 
No excerto anterior, temos 'the government's selective use of figures, fondness for comparing like with unlike, [...] are dogdy and dishonorable. But are the ministers lying?' It seems to me that one potential reason to think they are not is their own self-perception. Just as medieval peasants in France could not imagine a universe without god -such an idea was not within their range of thinkable thoughts -it is possible that Mr Brown and others simply cannot countenance the scale of the hole they have helped to dig [...]'. Ou seja, o autor oferece uma explicação que busca convencer o leitor de que seu argumento é válido. O que é comum no texto opinativo é a linguagem menos direta, como por exemplo, com o uso da metáfora em 'the scale of the hole they have helped to dig'. A estratégia utilizada, portanto, nesse tipo de texto, é apresentar um ponto de vista por meio de figuras de linguagem como comparações, metáforas, ironias.

O efeito de verdade produzido por cada tipo de texto (informativo e opinativo) se difere quanto à produção. No primeiro caso (artigos $A$ e B), esse efeito é dado através da construção de uma verdade consensual. A inclusão dos pronomes ' $l$ ' e 'we', as perguntas dirigidas ao interlocutor e o uso de asserções imperativas constituem o leitor como alguém que compartilha das ideias do texto.

No caso dos textos opinativos ( $C$ e $D)$, o efeito de verdade é criado pela construção argumentativa baseada na adjetivação, que é a tônica desse tipo de texto, refletindo opinião do enunciador. O uso da metáfora também faz parte da construção argumentativa desse tipo de texto.

Acreditamos que esses dois funcionamentos tenham por objetivo convencer de forma sutil, buscando o silenciar daquele que fala no discurso (o responsável pelo discurso), da seguinte maneira: no texto do tipo informativo, visa-se a um efeito de verdade, porém não de forma impositiva -cria-se, para isso, a aproximação com o leitor. No texto do tipo opinativo, não se quer impor a opinião de forma direta -recorre-se à argumentação com base na adjetivação e figuras de linguagem, o que produz o efeito de descrição. 
Foram analisadas as formas de inclusão e silenciamento da voz do interlocutor que, embora participe da produção do sentido a partir de formas por meio de inclusão pronominal, ao ser interpelado pelo locutor é levado a concordar com pontos de vista apresentados por este. A seguir, trataremos da análise de mais uma forma de silenciamento, porém, a partir da heterogeneidade mostrada e discutiremos de que forma ocorre um outro tipo de homogeneização.

\subsection{3- A heterogeneidade mostrada}

$O$ artigo intitulado 'Different goals' (artigo $E^{43}$ ) trata da fama do time Manchester United e de seu sucesso como empresa. O livro do professor traz um pequeno resumo do tema do exercício ('a text about Manchester United which demonstrates that football is big business and the football transfer system allows players to be traded for millions of pounds').

O texto oferece-nos marcas da presença do outro, na forma da heterogeneidade mostrada, nos seguintes excertos:

'Top clubs have grown on the back of television contracts' says Richard Baldwin of Deloitte \& Touche'.

'United look and behave very much like a traditional business from a corporate point of view', says Nigel Hawkins, a financial analyst at Williams de Bröe ${ }^{44}$ They have a strong brand and they have worked to maximize it by bringing in good people.

Ao atentarmos para os enunciadores dessas formulações, notamos que são britânicos. As citações acima referem-se a empresas de auditoria britânicas. Já a fala abaixo é de um antigo funcionário do clube Manchester United:

'It's an oil well', says Manchester United's former head of merchandising'.

\footnotetext{
${ }^{43} \mathrm{O}$ artigo completo está nos anexos.

${ }^{44}$ In Company Intermediate. Teacher's Book. 2002. p. 87.
} 
O clube inglês em questão, Manchester United, é exaltado, em todos os comentários, por citações produzidas por empresas também britânicas. O uso do discurso direto cria um efeito de verdade. Compara-se o clube a uma empresa de grande sucesso, ou seja, não se está diante apenas de um clube, mas de uma corporação, o que pode constituir-se em um diferencial frente aos outros times. Atentemos à ilustração a seguir:

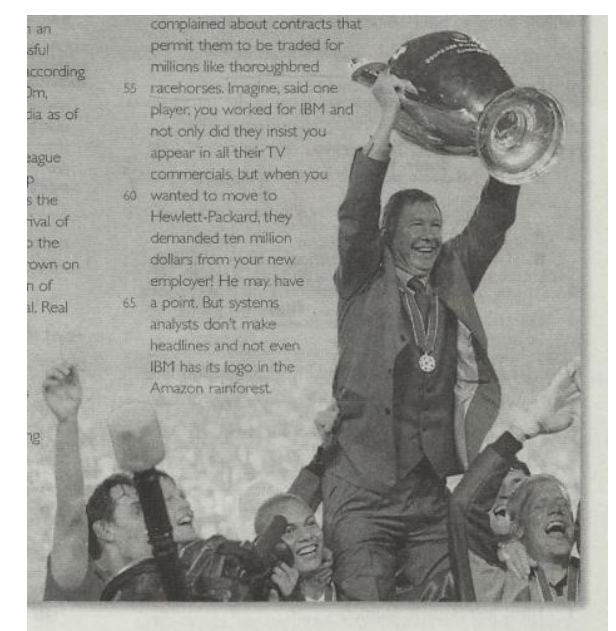

A foto mostra o treinador e dirigente atual do clube Manchester United (Sir Alex Alexander Chapman Ferguson) segurando o troféu, em meio aos jogadores do time, provavelmente depois de uma vitória em campeonato. Sir Alex apresenta-se acima de todos os outros, como líder, ou seja, na frente, numa posição privilegiada em relação aos demais membros da equipe. A impressão que causa no leitor é que o artigo é supostamente apresentado em seu formato original, já que o texto está impresso dentro de uma delimitação espacial no papel mais escura que a página do livro e há utilização da caixa alta. O técnico, na foto, não usa roupas esportivas: veste terno, gravata e calça social, o que vai ao encontro ao que o texto quer passar: que o time constituise num negócio, numa empresa, cujo líder é o treinador-chefe. Não há, nesse artigo, a indicação da fonte nem do jornalista e entendemos que essa ausência contribui para o efeito de texto enciclopédico, ou seja, que retrate características que se mantêm, diferentemente do jornalístico, que é uma atualização regular da notícia (diária, semanal, por exemplo). O que contribui para a tomarmos em seu caráter 'definitivo' é também a remissão a outro artigo, no primeiro parágrafo, que menciona o modo de vida de uma tribo que, embora remota em vários aspectos (não sabia nem o que era um 'carro' ou tido 
contato com uma pessoa estrangeira), seus membros vestiam a camisa do time Manchester:

There was a recent news report about an anthropologist who discovered a lost tribe in the Amazon whose way of life had hardly changed since the Stone Age and who had never seen a car or met a foreigner. What shocked her most about the natives, however, was not their strange social customs or mysterious religious rituals, but the fact that several of them were wearing Manchester United football shirts!

Ou seja, essa retrospectiva traz uma retratação científica da situação dada a investigação da antropóloga- e, aliada à alusão à história do time desde os anos de seu início, 1990 ('Since 1990, the club has won -to date -four League titles, a League Cup, three FA Cups' [...]), se distancia de uma cobertura da notícia na sua perspectiva mais imediata, que seria própria do texto jornalístico.

Uma curiosidade. Atentemos ao parágrafo seguinte ao da constatação da antropóloga, reproduzido abaixo:

Whether or not that report is true, what is certain is that Manchester United stopped being just a famous football team several years ago and became a highly successful multinational corporation.

É afirmado que pode não ser verdade o que foi dito no primeiro parágrafo, porém, isso vai de encontro com a principal meta do livro, ao utilizar artigos: trazer a verdade. Ora, é um funcionamento pelo menos contraditório.

Os leitores-alunos podem não saber quem está sendo representado na figura. Claro que supõem que seja alguém importante do time (depois da leitura), mas provavelmente não sabem com precisão.

O livro opta por trazer uma imagem privilegiada do time, com uma ilustração que mostra sua grandeza enquanto tal, mas também enquanto um negócio muito lucrativo, sentido que é fixado para o aluno.

De acordo com KRESS e LEUWEEN (1999: 383), o tipo de ilustração acima corresponde a uma 'imagem de oferecimento':

Here the viewer is not object, but subject of the look, and the represented participant is the object of the viewer's dispassionate scrutiny. No contact is made. The viewer's role is that of an invisible onlooker. All images which do not contain human or quasi-human participants looking directly at the viewer are of this kind. For this reason we have called this kind of image an 'offer' -it 'offers' the 
represented participants to the viewer as items of information, objects of contemplation, impersonally, as though they were specimens in a display case ${ }^{45}$.

Assim, é entregue um significado ao aluno (e aos outros leitores em potencial), onde não cabe questionamento ou participação na produção dos sentidos.

Podemos afirmar, ainda, que por 'oferecer' um significado, e não interpelar o interlocutor na participação ${ }^{46}$ do mesmo, essa representação exalta a cultura britânica, questão que discutiremos no capítulo seguinte.

Vejamos como a voz única do locutor novamente prevalece em outro artigo.

$\mathrm{O}$ artigo seguinte (artigo $\mathrm{F})^{47}$ trata de equipes virtuais de trabalho e seu desejo de obter e manter uma harmonia nessa forma de interação, que iniciase com o seguinte parágrafo:

If managing diversity in the workplace is a tough task for business leaders, the challenges of keeping executives from different backgrounds working together efficiently in various parts of the world is even more difficult.

Aparentemente, é um texto objetivo, sem pronomes pessoais de primeira pessoa, equiparando-se a um texto argumentativo. São apresentadas duas asserções, separadas por vírgula, como mostra o excerto anterior. Porém, essa característica não é mantida.

Abaixo, reproduzimos alguns excertos que exemplificam o uso da heterogeneidade mostrada e a seguir uma discussão sobre o modo como ela se apresenta.

A presença do outro se faz através de vozes de diferentes profissionais, como temos no excerto 9, em que uma professora da MIT Sloan opina. Ela utiliza, em sua fala, o deôntico 'should', que reforça o tom de autoridade do conteúdo que enuncia (trechos sublinhados):

\footnotetext{
${ }^{45}$ Grifos nossos.

${ }^{46}$ Veremos um exemplo de ilustração do tipo 'demanda' no capítulo 3.

${ }^{47} \mathrm{O}$ artigo está reproduzido nos anexos.
} 


\section{Excerto 9}

"One of the things you should take into account is whether your team includes members who don't speak English well", says Joanne Yates, a professor of management at MIT Sloan, who has studied the use of communication and information system in companies [...].

Já no excerto 10, um psicólogo britânico que compara equipes virtuais de trabalho a equipes presenciais utiliza a negação categórica (em destaque):

Excerto 10

"You don't build the relationships in the same way as you do face-to-face", says Martin Galpin, managing psychologist at Pearn Kondola, a UK-based research business and consultancy of occupational psychologists.

No próximo excerto, 11, a retomada da voz da professora Yates, que relata uma experiência com relação a uma mini conferência que observara. Observe-se o uso de advérbio de afirmação 'certainly', que provoca efeito de verdade, inquestionabilidade:

\section{Excerto 11}

And virtual working certainly does not eradicate the sort of cultural misunderstandings that can arise in a face-to-face situation. Prof Yates cites an online mini conference she recently observed that took place between a group of US and Japanese executives working in the research and development unit of a Japanese company. A Japanese executive was putting text into a window for instant messaging when one of the Americans started asking questions in the middle of the presentation," she explains. "That was not culturally familiar and required an instant response, which caused real problems."

As vozes são de profissionais ou ingleses ou validados pela mídia inglesa e, portanto, representam essa única voz. A heterogeneidade, em sua forma mostrada, oferece espaço a uma pluralidade de opiniões, porém, dentro de um mesmo círculo: circunscrito ao ponto de vista britânico.

Percebemos, mais uma vez, a referência a nomes de instituições logo após a reprodução da primeira fala de cada profissional, nos excertos 9 ('a professor of management at MIT Sloan') e 10 ('managing psychologist at Pearn Kondola, a UK-based research business and consultancy of occupational psychologists'). É a validação do discurso que ocorre a partir da sua ligação 
com as instituições, com uma voz já validada, que garante credibilidade. As duas últimas falas da professora Yates são bastante curiosas, pois antecipam 0 assunto de que trataremos no capítulo 3 , as representações. Nas sentenças ' $A$ Japanese executive was putting text into a window for instant messaging when one of the Americans started asking questions in the middle of the presentation", she explains' e "That was not culturally familiar and required an instant response, which caused real problems." apontam para uma marginalização das atitudes dos americanos, questão que será discutida no próximo capítulo.

As formulações analisadas têm em comum a presença de autoridades, especialistas que contribuem com seus pontos de vista sobre os temas nos artigos. Tendo em vista que o discurso da mídia é um discurso tido como verdadeiro, objetivo, ele se assemelha ao discurso científico, que cunha uma verdade no texto e que, por isso, ao constituir um texto jornalístico, reforça-o como fonte da verdade. Portanto, a presença de especialistas tais como psicólogos, gerentes, professores visa produzir um efeito de verdade através de conhecimento legitimado.

CARMAGNANI (2003: 110) afirma que a transposição de textos da mídia para o livro didático aumenta o efeito de verdade já produzido pelo discurso deste. Podemos ir além e acrescentar que o LDIN passa a ser fonte de conhecimento fixo a partir de um saber temporário (válido dentro de um espaço de tempo), ou seja, do conteúdo da mídia, que embora se atualize constantemente, seu caráter transitório não é percebido uma vez que está inserida no LDIN.

O que contribui para tal efeito de sentido na prática da sala de aula é a antecipação. Orlandi a define como um elemento preponderante no discurso. São imagens que estão presentes na situação de enunciação e que definem os papéis dos participantes. A imagem que o locutor faz da imagem que 0 interlocutor faz dele, e vice-versa.

Consideramos que a antecipação é uma característica bastante presente em situações de uso de livros denominados didáticos, pois tanto do lado dos locutores como dos interlocutores há projeções antecipadas de imagens que acreditamos ser estáveis e inquestionáveis. Assim, as imagens que um faz do outro são tão normalizadas e normalizantes que o jogo discursivo se torna 
altamente previsível e pouco passível de mudanças. No caso do LDIN, ao leitor-aluno é apresentado um conteúdo denominado objetivo, imparcial, mas que contém características que o fazem mostrar-se como um discurso subjetivo, que não deixa de mostrar a opinião do locutor e que interage com o leitor.

Com relação a esse ponto, em ORLANDI (2007: 20) afirma:

Compreender o que é efeito de sentidos é compreender que o sentido não está (alocado) em lugar nenhum, mas se produz nas relações: dos sujeitos, dos sentidos, e isso só é possível, já que sujeito e sentido se constituem mutuamente, pela sua inscrição no jogo das múltiplas formações discursivas (que constituem as distintas regiões do dizível para os sujeitos).

É, portanto, nas relações e nos jogos que as constituem que o sentido se forma: a intersubjetividade faz parte da produção dos sentidos. Com relação ao discurso científico, CORACINI (1991: 150) afirma que:

Desse modo, aceitar o outro na construção do discurso científico é aceitar a existência da intersubjetividade (subjetividade partilhada) como componente integrante da atividade de produção e de interpretação do discurso. É aceitar, na própria linguagem, a presença do convencional, resultante das relações e contratos sociais. Conclui-se daí que nenhum texto seria obra de um único indivíduo, mas do entrelaçamento de experiências e ideologias que pressupõem a presença ativa e efetiva do outro.

A citação, embora se refira ao discurso científico, pode ser pensada em termos do discurso jornalístico, na medida em que ambos visam a persuadir, no sentido de mostrar que um discurso é a manifestação da verdade, e que traz ao interlocutor dados comprovados e/ou constatados. Os discursos de verdade aqui trabalhados (do livro didático, da ciência e da mídia) mutuamente se reforçam, visando a um efeito de verdade cada vez mais eficaz.

AUTHIER-REVUZ (1998:124) faz uma afirmação que pode ser pensada em termos da mídia e complementa a questão dos jogos discursivos de Orlandi:

A encenação da transmissão (com uma estrutura de "lugares", seu trabalho mostrado) tem por função paliar (esconder, camuflar), através de uma construção interna ao discurso, a falta da estrutura pedagógica de que é provido, imediatamente, de modo externo, o discurso didático sustentado nos quadros do aparelho escolar. Modo de essa D.C. instituir-se como prática didática, esta construção pelo discurso da relação pedagógica manifesta, ao mesmo tempo, a fragilidade de uma legitimidade autoproduzida, em função da relação do discurso com a instituição. 
O discurso da mídia é um discurso de transmissão de conhecimento legitimado e, tal como o pedagógico, suscita pouco ou nenhum questionamento quanto à sua validade, por isso mesmo, esconde ou camufla os lugares na situação comunicativa. Produz a si mesmo, então, uma legitimidade, que tornase parâmetro para um discurso estável.

Daí decorre a reflexão de AUTHIER-REVUZ (2004: 42):

\begin{abstract}
O discurso (como qualquer signo, em geral) é interindividual. [...] não se pode atribuir o discurso somente ao locutor [...] Cada enunciado tem sempre um destinatário [...] e o autor da obra verbal procura e antecipa a compreensão responsiva.

Visando à compreensão de seu interlocutor, o locutor integra, pois, na produção de seu discurso, uma imagem do 'outro do discurso', aquele que ele empresta a seu interlocutor.
\end{abstract}

Essa 'imagem do outro' constitui-se nas posições de sujeito no discurso. Dizer que todo discurso implica duas instâncias, ou seja, aquele que o produz e aquele que o lê (ou ouve), não é dizer que essas instâncias são simétricas. Essa dupla participação na produção discursiva envolve, em cada tipo de discurso, enquanto estrutura, um locutor e um interlocutor, mas enquanto acontecimento, uma atitude responsiva que mobiliza formações discursivas específicas, ou seja, algo aquém, mas também além das posições dos sujeitos discursivos.

Nos três tipos de artigos analisados, os textos são caracterizados como 'artigos', porém, cada um traz elementos subjetivos.

No primeiro tipo de texto (seção 2.2.1), o uso de pronome de primeira pessoa do singular que desliza para a segunda pessoa do plural faz com que 0 texto se aproxime, inevitavelmente, do leitor, este não enquanto produtor de significado, mas enquanto sujeito interpelado discursivamente a concordar com o texto, o que também é verdade no segundo artigo cujas perguntas têm o mesmo efeito. Assim, atestam a não-impessoalidade dos textos.

No segundo tipo (seção 2.2.2), a presença de adjetivos e a referência às expectativas do interlocutor também representam uma aproximação com este, ou seja, um posicionamento subjetivo como modo de tratamento do tema.

Nos últimos dois artigos (seção 2.2.3), por meio da heterogeneidade mostrada, discutimos a presença do outro, mas que revela opiniões e observações a partir de vozes da mídia britânica apoiados em instituições de prestígio, ou seja, o ponto de vista declarado restringe-se à esfera britânica, 
que opinam também nos jornais britânicos. A impressão que se cria a partir da heterogeneidade mostrada é de objetividade e imparcialidade, porque significa a voz legitimada de quem de direito, porém esta encontra-se circunscrita somente à perspectiva britânica. Acerca dessa questão, CORACINI (1997: 40) afirma:

\begin{abstract}
Heterogeneidade, dialogismo, alteridade constituem termos que [...] questionam a unicidade de todo dizer, apontando para a presença do outro no dizer daquele que aparenta o um. Presença do outro que se dá ao 'um', na forma de pensar e de ver o mundo, na forma de ser. Falar do outro não é simplesmente falar do alterego, nem da presença do interlocutor com quem se dialoga prevendo suas reações em todo e qualquer esforço de comunicação. Falar do outro significa postular sua presença na constituição de todo e qualquer discurso e, consequentemente, a ideologia como constitutiva das relações sociais.
\end{abstract}

Assim, nos três casos, através de um discurso com marcas subjetivas, constatamos que se há heterogeneidade pela presença de 'outros'; seu efeito é, em contrapartida, de homogeneização. A heterogeneidade acaba sendo um outro que é o 'mesmo', é a homogeneidade discursiva representada pela presença de elementos subjetivos que prevalece, a despeito da heterogeneidade. Ou seja, a 'autenticidade', entendida como a presença de artigos da mídia, apaga a constituição ideológica das formulações. Nem a assinatura de um artigo por um jornalista, nem a presença de especialistas ou o próprio fato da notícia vir do jornal faz com que uma análise discursiva deixe de constatar a presença ideológica, ou seja, uma tomada política de opinião. 0 discurso jornalístico está cercado por pontos de legitimação, seja o jornal, os especialistas, as instituições a partir das quais os especialistas falam.

FOUCAULT (1979b), em seu texto 'What is an author?', faz uma reflexão interessante sobre a questão da autoria. Afirma, por exemplo, que o nome do autor serve para caracterizar um certo modo de existência de um discurso, de modo que dizer que um texto fora escrito por um autor específico mostra que o discurso não se constitui em fala cotidiana, e por isso é recebido de um certo modo e, numa dada cultura, possui um status específico. A função do autor é característica do modo de existência, circulação e funcionamento de certos discursos numa dada sociedade.

Sobre este ponto, SOUZA (1999: 29) afirma que:

A noção de autor do livro didático e que faz parte da crença predominante entre professores o configura enquanto aquele que é 
responsável pelo que "diz" no livro didático; pelo conteúdo que ele seleciona; pela forma de organização do conteúdo selecionado e pela forma de apresentação desse conteúdo, a sua competência enquanto autor é, geralmente, medida pelo caráter de clareza didática, avaliada em termos da linguagem utilizada no livro [...].

No caso do LDIN, verificamos que embora haja injunção a certas autorias, como, por exemplo, os jornalistas e os especialistas, a dispersão de sujeitos-enunciadores permeia os textos produzindo, portanto, pontos de vista que embora originados de um só ponto, ou seja, do Locutor, representam diversas outras vozes, que muitas vezes não são identificáveis e mesclam-se com aquele que seria responsável pelo dizer, no caso, o LDIN.

A autoria, segundo FOUCAULT (1971: 26), funciona como um princípio de rarefação do discurso, ou seja, como um elemento que apaga a materialidade deste, naturalizando sentidos. A autenticidade pode ser caracterizada como uma variação da autoria pois, como esta, funciona representando a origem do discurso e, assim, indica uma verdade: "O autor é aquele que dá à inquietante linguagem da ficção suas unidades, seus nós de coerência, sua inserção no real" (idem, op. cit., p. 28). O termo 'real', como já vimos, aparece nas formulações dos excertos, significando verdade, em oposição a um discurso de ficção, ou inventado. 'O princípio do autor limita o acaso do discurso pelo jogo de uma identidade que tem a forma da individualidade e do eu'. A dispersão, assim, toma forma a partir do princípio do autor que, por estar constituído a partir de seu lugar social e falar de dentro do aparato institucional, tem seu discurso validado.

O Locutor, nos casos acima, é o jornalista, porta-voz do jornal. Porém, as outras vozes são constitutivas de seu discurso, como identificamos, mas acabam sendo camufladas ou vinculadas à voz do jornal, e a heterogeneidade, mesmo que explícita ou mostrada, não significa uma abertura a diferentes vozes. Por isso podemos afirmar que instaura-se uma homogeneização através da heterogeneidade. Em seu trabalho sobre a argumentação, BRANDÃO (1998: 42) afirma que a heterogeneidade é trabalhada pelo locutor de tal forma que, 'impulsionado por uma vocação totalizante', faz com que o texto adquira, na forma de um concerto polifônico, uma unidade, uma coerência, quer harmonizando as diferentes vozes, quer 'apagando' as vozes discordantes. $O$ efeito de verdade vem justamente dessa unidade, dessa harmonia discursiva que faz a polifonia ressoar unívoca. 
O sujeito-aluno constitui-se a partir de uma pluralidade de vozes, mas numa homogeneidade enquanto sentido, pois circula dentro de formações discursivas específicas e que apagam outras possibilidades de vozes.

Não podemos nos esquecer de que a questão da autoria não se relaciona exclusivamente ao(s) autor(es) no LDIN, mas implica também o aparato institucional-editorial: esses livros são produzidos por renomadas editoras de universidades e, assim, são constituídos por esses discursos. SOUZA (1999: 28) afirma que 'é nesse contexto institucional que o livro didático se constitui. $\mathrm{O}$ autor do livro didático passará sempre pelo crivo editorial:

O aparato editorial funciona, de forma drástica, para manter determinados padrões em termos de livros didáticos, motivados por uma combinação de razões de ordem ideológica e razões econômicas -o livro que fará mais sucesso será aquele que venderá mais exemplares.

É por essa razão que não podemos delegar exclusivamente ao(s) autor(es) do livro o conteúdo e funcionamento destes, porque o LDIN precisa ser um sucesso de mercado, e por isso constitui-se, também a partir do discurso econômico. As vozes que vêm do discurso científico acabam, portanto, sendo fixadas.

DELEUZE (1988: 21) confirma essa exterioridade enquanto condição discursiva, ao distinguir três espaços em torno de um enunciado. O último deles consiste no espaço complementar, ou de formações não-discursivas. São as instituições, os acontecimentos políticos, as práticas e processos econômicos:

\begin{abstract}
Uma instituição comporta ela mesma enunciados, por exemplo, uma constituição, uma carta, contrato, inscrições e registros, Inversamente, os enunciados remetem a um meio institucional sem o qual os objetos surgidos nesses lugares do enunciado não poderiam ser formados, nem o sujeito que fala de tal lugar (por exemplo, a posição do escritor numa sociedade, a posição do médico no hospital ou em seu consultório, em determinada época, e o surgimento de novos objetos).
\end{abstract}

Bem, já o dissemos, se os discursos não se constituíssem a partir das validações das universidades, da editora, dos jornais, dos autores, não funcionariam como discursos de verdade; só são formados enunciados verdadeiros a partir dessa inscrição institucionalizada. 
O LDIN corresponde, assim, a uma materialidade que funciona sob regimes de verdade, ou seja, funciona como um discurso de verdade (o discurso do livro didático) e por isso pode fazer funcionar outros (seu conteúdo). Assim, ele existe sob um regime de verdade, que é o 'ser um livro didático', mas constitui-se, a partir desse ponto, em um regime de verdade, que instaura outros discursos verdadeiros. FOUCAULT (1969: 32) afirma que:

Fazer aparecer, em sua pureza, o espaço em que se desenvolvem os acontecimentos discursivos não é tentar restabelecê-lo em um isolamento que nada poderia superar: não é fechá-lo em si mesmo; é tornar-se livre para descrever, nele e fora dele, jogos de relações.

A importância da análise das sínteses 'discurso autêntico' e 'voz do outro' mostram, portanto, o jogo de relações aí implicado, evidenciando as contradições e, consequentemente, desnaturalizando evidências.

Em resumo, o foco deste capítulo foi trabalhar as vozes do discurso do LDIN; constatamos que a presença do outro nem sempre significa circular por outras formações discursivas, mas sim manter-se na mesma região de significação. Vejamos, no capítulo a seguir, os sentidos que as culturas, faladas por essas vozes, adquirem, e um tipo de silêncio que decorre dessas representações. 


\title{
CAPÍTULO 3
}

\section{AS REPRESENTAÇÕES CULTURAIS E OS REGIMES DE VERDADE}

\begin{abstract}
Vivemos em uma sociedade que em grande parte marcha "ao compasso da verdade" -ou seja, que produz e faz circular discursos que funcionam como verdade, que passam por tal e que detêm por este motivo poderes específicos. (FOUCAULT, 1979a: 231)
\end{abstract}

Uma vez analisados os regimes de verdade que colaboram para a instauração da verdade no LDIN no capítulo anterior, passaremos a verificar o modo de funcionamento de seu discurso ao analisar os efeitos de sentido produzidos no que tange à representação de culturas em geral e, em específico, das culturas britânica e norte-americana. Analisaremos, também, que tipo de sujeito-aluno é pressuposto nessa prática discursiva ao analisar em que medida o aluno, enquanto sujeito de um saber, participa da construção dos sentidos desses textos. Acreditamos que o modo de funcionamento do LDIN oferece um espaço à voz do aluno de maneira específica.

Analisaremos trechos de transcrições dos exercícios de compreensão oral e de textos de leitura, porém, antes de nos determos na análise das representações, são necessários alguns paralelos entre a mídia impressa e a mídia no LDIN, tendo em vista que a maioria dos trechos analisados são extraídos da mídia impressa.

\begin{tabular}{|l|l|}
\hline \multicolumn{1}{|c|}{ Mídia Impressa (jornal/ revista) } & \multicolumn{1}{|c|}{ Mídia no LDIN } \\
\hline Possui vários textos & $\begin{array}{l}\text { Possui, geralmente, um texto por } \\
\text { unidade }\end{array}$ \\
\hline Apresenta o texto completo & Apresenta o texto adaptado \\
\hline $\begin{array}{l}\text { O leitor foca nas partes do texto que julga } \\
\text { interessantes a partir de uma leitura } \\
\text { pessoal, selecionando seu percurso, a } \\
\text { escolha de textos }\end{array}$ & $\begin{array}{l}\text { O usuário lê o texto inteiramente (às } \\
\text { vezes mais de uma vez) para fazer os } \\
\text { exercícios correspondentes }\end{array}$ \\
\hline A leitura acontece num contexto real & $\begin{array}{l}\text { A leitura acontece fora de contexto ou } \\
\text { em contextos estabelecidos ou } \\
\text { situados pelo LDIN }\end{array}$ \\
\hline Leitores têm acesso a notícias a partir & \begin{tabular}{l} 
Usuários lêem notícias da mídia \\
\hline
\end{tabular}
\end{tabular}




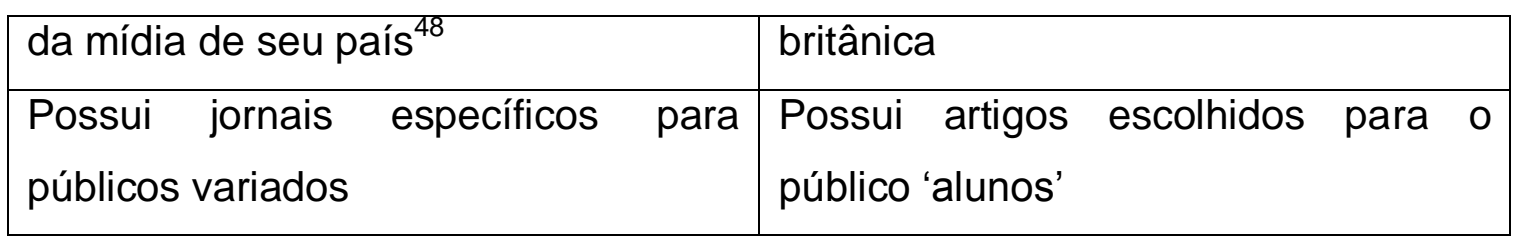

Assim, a mídia no LDIN possui características diferentes daquelas de seu uso habitual e dá lugar a um modo de funcionamento que a fixa como um texto enciclopédico, que contém a definição real e final sobre um conceito.

O jornal, na sua forma original, contém vários textos e muitas vezes o mesmo assunto é reportado por dias, semanas ou até anos. Vai-se construindo no leitor um encadeamento de atualizações sobre um fato, desde seu aparecimento até seu desfecho. Já no LDIN, é escolhido um artigo que corresponde a apenas um dos desdobramentos de um mesmo fato, silenciando outros que igualmente fazem parte do assunto, mas que por não estarem no LDIN, acabam não sendo acessíveis aos seus usuários.

Esse mesmo desdobramento não corresponde a um texto completo ${ }^{49}$, mas adaptado, que o LDIN defende como forma necessária devido a restrições lingüísticas por parte de seus leitores (os alunos), alegando que estes precisam estar em contato com uma linguagem 'tão facilitada quanto seu nível de linguagem permita' para compreender bem o texto. Apaga-se, assim, o fato de haver recortes e montagens na mídia impressa convencional, que estão ligados à pauta estabelecida, à linha editorial e ao espaço que o texto pode ocupar. Por isso que com essa adaptação vêm cortes, recortes, montagens pois, uma vez que há essa possibilidade, um novo texto é escrito.

Ao ler um jornal comum, o leitor dá prioridade a notícias específicas, a cadernos específicos, de acordo com seu próprio interesse. Até mesmo lê os artigos parcialmente ou somente o título dos mesmos. No LDIN, contudo, o texto inserido é de leitura obrigatória e, diríamos que o que também é praticamente obrigatório é o mínimo de duas leituras, pois o livro pressupõe que, ao fazer isso, o aluno retome estruturas, vocabulário, enfim, o conteúdo gramatical a partir do texto.

\footnotetext{
${ }^{48}$ Claro que, com a Internet, há a possibilidade de acesso a páginas internacionais de notícias, mas podemos dizer, comumente, que o aluno tem mais acesso, principalmente, à mídia de seu país.

${ }^{49}$ Vale ressaltar que os próprios textos da mídia são montados e recortados para se adequarem ao discurso do jornal ou revista em questão e aos seus leitores em potencial.
} 
O artigo está inserido no livro didático dentro de uma unidade específica, que tem como objetivo propor e explorar um conceito em particular. Ou seja, a leitura é feita segundo uma perspectiva pré-definida que interfere nas diversas possibilidades de leitura. Já com relação à notícia em seu uso habitual, o contexto não é apresentado, pois a notícia diz respeito aos acontecimentos de seu tempo e espaço (local $)^{50}$. Além disso, as notícias veiculadas no livro didático são da mídia britânica, portanto têm enfoques e perspectivas circunscritos a essa cultura e aos interesses dos seus grupos editorais, deixando de ter outros pontos de vista apresentados. Assim, os alunos não têm contato com outras mídias e a britânica passa a ser a única referência para os conceitos - havendo, portanto, uma unicidade de vozes- questão já analisada no capítulo anterior.

Discutiremos, a seguir, como essas diferenças interferem na produção de sentidos nos livros didáticos de nosso corpus.

\section{1- Homogeneização dos aspectos culturais}

Observamos que a representação das culturas no discurso do LDIN é feita por meio de três modos principais:

- apagando as diferenças existentes dentro de uma mesma cultura, criando a impressão de que suas características são fixas e que, portanto, basta seguir algumas regras para que se possa aprender a lidar com elas;

- predicando/ caracterizando os países a partir de uma notícia ou um recorte desta.

- apresentando as culturas como benéficas ou maléficas, conforme discutiremos em 3.2 .

Sendo assim, haveria, de acordo com o primeiro tópico, um modus operandi com relação às culturas, já que se pressupõe que elas são dotadas de características fixas. $O$ segundo tópico foca uma predicação

\footnotetext{
${ }^{50}$ Mesmo que as notícias sejam sobre outros países ou regiões que não a do leitor habitual, cabe a ele estar a par desses acontecimentos. Raramente é oferecido um panorama completo da notícia num jornal ou revista comum, a não ser em documentários ou reportagens em edições especiais.
} 
homogeneizante; a partir de estórias sobre as nações, criam-se imagens sobre como estas são ou agem, nas suas relações com outros países. Há de se destacar, ainda, que dois países são colocados em oposição (Estados Unidos e Inglaterra), assunto do terceiro tópico.

A análise buscará mostrar como as formulações sobre as culturas no LDIN produzem um efeito de congelamento de sentidos e, assim, apontam para uma forma específica de identidade ao tratar desses países. Por meio de uma reflexão crítica dos processos de significação no LDIN, discutiremos também a questão do silêncio.

ORLANDI (2007: 72) afirma que:

Desde que nos propomos uma reflexão crítica sobre os processos de significação, não mais nos limitamos à busca de unidades discretas. Se a matéria significante do silêncio é diferente da linguagem verbal, essa diferença deve ser levada em conta pela análise.

Analisar a língua em seu caráter formal consiste em partir das palavras para buscar o que elas querem dizer na superfície linguística, ou seja, os sentidos dicionarizados. A palavra, assim, seria analisada como uma sequência de unidades de sons que tem um significado específico. Analisar desse ponto de vista é limitar-se à busca de unidades discretas. Nosso objetivo, porém, não será analisar o conteúdo textual dos excertos, mas observar os modos de construção dos sentidos produzidos e os que são silenciados.

Para uma análise que não toma por base a língua enquanto sistema formal é preponderante o conceito de metáfora segundo PÊCHEUX (1975). Para o autor, a metáfora é central para a constituição dos sentidos, sendo constitutiva deste. Diferentemente da idéia de metáfora como figura de linguagem ou desvio ao sentido literal, o conceito de metáfora em Pêcheux constitui-se num deslize de sentidos, ou seja, o dizer torna-se um outro dizer.

Uma palavra, uma expressão ou uma proposição não tem um sentido que lhe seria próprio, preso à sua literalidade; [...] o sentido é sempre uma palavra, uma expressão ou proposição por uma outra palavra, uma outra expressão ou proposição; e esse relacionamento, essa 
superposição, essa transferência (meta-phora), pela qual elementos significantes passam a se confrontar, de modo que "se revestem de um sentido", não poderia ser predeterminada por propriedades da língua; isso seria justamente admitir que elementos significantes já estão, enquanto tais, dotados de sentido, que tem primeiramente sentido ou sentidos, antes de ter um sentido. De fato, o sentido existe exclusivamente nas relações de metáfora [...]. (PÊCHEUX, 1975: 240)

Segundo o autor, portanto, também não cabe analisar a língua a partir de uma perspectiva do significante, pois o revestiria, de antemão, de um sentido definitivamente estável, bloqueando possibilidades de remissão a outras formações discursivas, que igualmente são possíveis, mas dessa forma estariam indisponíveis. Uma vez que o sentido é produzido nas relações com outros, é infértil, para a análise, tomá-lo no conforto do significante. É, portanto, necessário um dispositivo que permita esse movimento e o uso do conceito de metáfora na análise se faz pertinente.

ORLANDI (1999: 44) afirma que a metáfora não é considerada, como na retórica, um tipo de figura de linguagem; na $A D$, é definida como 'a tomada de uma palavra por outra', significando "transferência", 'estabelecendo o modo como as palavras significam'. Observaremos, principalmente nas seções 3.2.1 e 3.2.3, como a metáfora funciona no discurso do LDIN, atuando nas formulações e assim transferindo seus sentidos para outros lugares, mobilizando sentidos produzidos, ou seja, remetendo a formulações já produzidas e antecipando novas interpretações.

Dois artigos, $\mathrm{G}$ e H, apresentam as culturas da Itália e a dos Emirados Árabes Unidos. As culturas brasileira e sul-coreana também são apresentadas na unidade em que eles se encontram, porém não no corpo desta, mas em 'activity files'51 no final do livro. O conhecimento produzido diz respeito a atitudes que um visitante a negócios no país em questão deva ter se deseja obter sucesso na negociação. Ambos são divididos em 'Conversation', 'Gift

\footnotetext{
51 'Activity files' são anexos dos exercícios das unidades e se encontram no final da coleção Market Leader. Os artigos sobre o Brasil e sobre a Coréia do Sul estão reproduzidos nos anexos.
} 
Giving' e 'Entertaining'. Verificaremos quais e como certos recursos argumentativos utilizados pelo LDIN produzem a homogeneização do sentido.

O uso de certas palavras e expressões categóricas (em itálico) e de alguns advérbios (em negrito) merecem destaque. Vejamos essa questão no artigo sobre a Itália:

Article G: Italy

\section{Conversation}

Lively conversation is common in Italy. Welcome topics of conversation include Italian architecture, art and films, sports (especially football), opera and praising the hospitality of the country! It is best to avoid criticising Italian culture, even if your counterparts are doing so.

\section{Gift Giving}

Don't give a business gift until you receive one. Your gift should be a well-known brand name. Gifts of alcohol or crafts from your country are often good choices. Other possible gifts are fine pens, a framed print or picture, silver key rings or calculators. Avoid giving gifts showing your company's logo.

\section{Entertaining}

Hospitality plays a key role in Italian business culture. Regardless of how you feel, refusing an invitation of any kind may give offence. The business breakfast is almost unheard of. Rare exceptions may be found in major cities. Business dinners involve only a small, exclusive group. If you are the host, check with your Italian contact before making any invitations. Lunch is still the main meal of the day in most areas of the country. It is usually served after 12:30 p.m. and often has many courses.

Por meio de alguns verbos na terceira pessoa do presente atemporal, como 'is', 'include', 'plays', 'involve', são fixadas maneiras de lidar com a cultura: 'Lively conversation is common in Italy', 'Welcome topics of conversation include Italian architecture, art and films, sports (especially football), opera and praising the hospitality of the country?', 'Hospitality plays a key role in Italian business culture', 'Business dinners involve only a small, 
exclusive group'. O uso de advérbios aumenta o efeito de verdade ('often', 'only'), produzindo generalizações de tempo e exclusão, respectivamente.

Essas características são também encontradas no artigo sobre os Emirados Árabes Unidos, como é mostrado a seguir (as formulações categóricas estão em itálico e os advérbios em negrito).

Article H: United Arab Emirates

\section{Conversation}

The hosts usually set the subject of the conversation. They will normally begin with polite enquiries (How are you? How are you enjoying your visit? etc.). If others arrived before you, your hosts will often tell you the subject of the conversation and invite you to contribute.

\section{Gift Giving}

Gift giving in the UAE is more complex than any in other countries. This is partly because of the mixture of nationalities: each nationality has different tastes and customs. Also, nearly everything can be purchased in the UAE less expensively than anywhere else in the world. As a gesture of respect, your host is likely to open and carefully examine your gift in your presence. It is important that your gift is the best you can afford to avoid embarrassment'

\section{Entertaining}

Sharing a meal is considered the best way for people to get to know each other. Locals often entertain at home but they will accept a foreigner's invitation to a hotel or restaurant. Hospitality in the UAE is very important but should not be interpreted as future commercial success. There are local customs to be aware of, for example, it is considered bad manners to either eat or offer something with the left hand.

No artigo $\mathrm{H}$, encontramos algumas afirmações categóricas, tais como: 'They will normally begin with polite enquiries (How are you? How are you enjoying your visit?)', 'Gift giving in the UAE is more complex than any in other countries' e 'There are local customs to be aware of. O uso de advérbios ocorre em algumas formulações, das quais destacamos algumas: 'The hosts usually set the subject of the conversation', 'Also, nearly everything can be 
purchased in the UAE less expensively than anywhere else in the world', 'Locals often entertain at home'.

CORACINI (1991: 113) afirma que o uso de asserções categóricas assemelha-se a enunciados ditos 'gerais e universais' (como por exemplo, 'A Terra é redonda' ou 'A Terra gira em torno do sol'). A autora ressalta, ainda, que mesmo essas orações "só são verdades com relação a um sistema de crenças, um estado de saber, um ponto de vista, um modo determinado de apreensão do real". Ora, as formulações sobre modos de lidar com culturas nos exemplos destacados dos artigos assemelham-se a essas asserções, uma vez que utilizam verbos no presente, de forma assertiva. A impressão que se tem é que estamos diante da objetividade, da neutralidade e que somente há essa forma de representação dos países.

Outra característica importante na produção de sentidos fixos sobre as culturas se dá por meio de verbos modais (sublinhados nos dois artigos), que embora tentem amenizar o tom categórico de que são providas a maioria das formulações, acabam por produzir formulações que se equiparam a verdades, como por exemplo 'Your gift should be a well-known brand name'. Aqui, o modal 'should' poderia ser substituído por 'must' ou por uma formulação imperativa 'Bring a well-known brand name as a gift'. O efeito seria o mesmo, já que o que se quer dizer é que há maneiras a serem seguidas para se ter sucesso enquanto visitante a um país. Outros exemplos (sublinhados nos dois textos) são: 'refusing an invitation of any kind may give offence', 'Rare exceptions may be found in major cities', (artigo sobre a Itália) e 'Hospitality in the UAE is very important but should not be interpreted as future commercial success' (artigo sobre os Emirados Árabes Unidos). Além disso, se compararmos a quantidade de formulações modais com as categóricas, percebemos que as do primeiro tipo são em menor número, ou seja, as categóricas são as mais utilizadas.

O uso do imperativo é bastante frequente nos artigos. Faremos duas observações quanto a ele: a primeira remete a fixar modos de como lidar com 
os povos, representando-os de uma forma totalizante e homogênea. Observese as seguintes formulações:

'Don't give a business gift until you receive one' $e$

'Avoid giving gifts showing your company's logo'

$\mathrm{Na}$ formulação 'Don't give a business gift, unless you receive one' ocorre, novamente, uma homogeneização da cultura, e assim cria-se a impressão de uma forma única de costumes existente na cultura. Já ao dizer 'Avoid giving gifts showing your company's logo' o enunciador interpela, por uma ordem, o indivíduo a agir segundo os modelos culturais apresentados nessas representações, caso ele entre em contato com a cultura. Na seção 'Entertainment' do artigo sobre a Coréia do Sul (artigo I), encontra-se a sentença imperativa 'Make sure that you know one very simple song and do your best' e uma asserção categórica 'Refusing to sing is considered bad manners', entre outras. A mesma seção do artigo sobre o Brasil (artigo J) traz o imperativo 'Cut all foods, including fruit and sandwich, with your knife'. $\mathrm{Na}$ seção 'Gift-giving' sobre o Brasil, há um exemplo do imperativo negativo: 'Do not give anything that is obviously expensive,52.

CORACINI (1991), ao tratar das validações que podem ser cientificamente comprovadas, afirma que ainda essas possuem traços que atestam sua relação com o sujeito- enunciador. A autora acrescenta que, ao pronunciar um discurso de natureza científica, o locutor assume o conteúdo do enunciado e se compromete com a verdade que enuncia, de modo que não é possível separar a análise das asserções do sujeito-enunciador, ainda que este esteja totalmente ausente da cadeia linguística. Em se tratando de aspectos culturais, essa relação subjetiva fica ainda mais evidente por duas razões: não referem-se a fenômenos comprováveis cientificamente e giram em torno de sujeitos que, por definição, são constituídos na historicidade, ou seja, no modo como as relações culturais, sociais, históricas, políticas e econômicas são produzidas e circulam na sociedade.

\footnotetext{
${ }^{52}$ Os artigos sobre a Coréia do Sul e o Brasil encontram-se no anexo.
} 
As formulações no LDIN são totalizantes, uma vez que buscam fazer com que as características sejam aplicadas a todos da cultura; não há, por exemplo, o uso de recursos que mostrem a existência de diferenças nos aspectos culturais, mesmo sendo essa característica encontrada na representação dos Emirados Árabes Unidos: 'in UAE each nationality has different tastes and customs'. Os pronomes indefinidos (como 'alguns', 'algumas', 'a maioria'), que poderiam agrupar e definir um grupo restrito ao qual se aplicaria tais descrições, não fazem parte dos artigos. Os verbos modais, como vimos, embora utilizados, não deixam de ter a força causada por meio das formulações assertivas e imperativas. Tais ausências causam um efeito de verdade e evitam possíveis questionamentos e refutações sobre aquilo que está sendo enunciado.

Os exercícios relacionados ao artigo apenas retomam o conteúdo dos mesmos, exigindo do aluno que simplesmente encontre nos textos em qual país certas atitudes são recomendadas ou não. Os exercícios relacionados a essas representações apenas as reforçam:

In which country or countries:

1 - do people talk in a lively way?

2- do people ask questions about your personal life?

3- does the host invite you to comment on a previous conversation?

4- do the hosts like to hear praise about their country?

Observe-se que há apenas o uso do 'do' e 'does' nas perguntas, ou seja, é enfatizado o modo fixo das características, não questionando as diferenças culturais.

Um outro exercício segue o mesmo parâmetro:

Divide the SS into pairs from the same country. Get them to give prepare some advice of the kind they have seen in the articles. Allow five minutes for preparation, then get pairs to come to the front of the class to give their minipresentations.

Ou seja, os alunos têm a tarefa de memorizar as regras culturais e elaborar uma mini-apresentação sobre elas e, assim, não têm a oportunidade 
de levar em consideração possíveis críticas ou diferenças culturais; mesmo que elas sejam pressupostas na própria seção 'Business Brief' ${ }^{53}$ da unidade:

Clearly, we live in a set of cultures and subcultures that interlock in complex ways and, to make a generalisation, one of the most dangerous things is to generalise about them. Stereotypes are, of course, to be handled with caution. The stereotype may represent the middle of a range of different behaviours, it may be at one extreme or it may just not be true. And there may be more variety in behaviour within a culture than between one culture and another.

A parte sublinhada vai ao encontro de nossa perspectiva: não há como generalizar os comportamentos e, consequentemente, os modos de lidar com as culturas. Não se trabalha a questão do efeito de homogeneização, esta é tomada como natural nos exercícios, porém como não natural na apresentação da unidade, como vimos no excerto anterior. Assim, a alteridade (o outro, a cultura do outro) não é o que podemos ver como preocupação do livro didático, pois este não abre espaço para o trabalho das diferenças, constituindo-se, assim, em um espaço onde somente há reprodução.

A seguir, vejamos outra forma de representação.

O próximo exercício faz parte de uma seção denominada 'Case Study', que traz uma problemática a ser discutida e solucionada pelos alunos. Em resumo, a situação apresentada é que há uma loja de brinquedos nos Estados Unidos (Toyworld) que tem subsidiárias no mundo todo e compra mercadorias de vários fornecedores por todo o mundo. $O$ aluno deve imaginar que um dos representantes de vendas de uma empresa fabricante de brinquedos da China e seu gerente irão visitar a subsidiária da loja em seu país (do aluno) para conhecer melhor a gerência da empresa, aprender mais sobre ela e, potencialmente, fazer negócios. Um dos exercícios constitui-se em um e-mail do gerente de Marketing da Toyworld (o aluno deve imaginar ser este) para o gerente de relações públicas da empresa fornecedora dos brinquedos; entre outras solicitações a ter em mente na escrita do e-mail, pede-se que se leia outro e-mail (do 'chief executive' da Toyworld), do qual o trecho seguinte faz parte:

53 'Business Brief' é uma seção introdutória das unidades da série Market Leader no livro do professor. 
Above all, we do not want to make any cultural mistakes during the visit. We want Mr. Chung and Mr Wong to leave with an excellent impression of our company and the way we treat foreign visitors. To help you plan the visit, please could you attend the talk by Catherine Eng (an expert on Chinese business culture).

Notamos, assim, o tratamento à cultura sob uma perspectiva determinista, que a torna um objeto de conhecimento estável: há um modo fixo de conhecimento cultural, basta aprender e aplicá-lo. Visa-se a que não seja cometido nenhum 'erro cultural' por parte da Toyworld. A seguir, a reprodução do exercício de compreensão oral, onde, novamente, colocamos em itálico as palavras e expressões categóricas e em negrito os advérbios. Notamos que o uso do 'will' é frequente e tem a mesma função das afirmações categóricas, pois representam atitudes a serem tomadas para o sucesso quando do contato com a cultura; sublinharemos suas ocorrências.

(CE = Catherine Eng)

CE: I'll talk first about building relationships with the Chinese, then move on to suitable conversation topics. After that, l'll comment on gift-giving and, finally, mention a couple of points to think about when dealing with Chinese visitors.

It's important to remember that business relationships with the Chinese are built on personal trust and respect. Everything you do during visits must show that you consider your visitors to be important people. Developing a personal relationship and having a good social programme will often be more important than a business meeting.

Remember that status is important. The most senior person may not speak English as well as other, more junior, members of de group. However, you should pay careful attention to everything that person says.

Make an effort to learn and use a few words in Chinese. (1) Your visitors will appreciate this. If there's someone in your company who speaks Chinese, it may be better to use that person instead of a professional interpreter. (2) It will be cheaper and the Chinese may trust a company member of staff more quickly.

Be careful about topics for discussion at social events. Don't embarrass visitors by introducing 'difficult' topics. (3) They will be eager to learn about life in your country and about its culture. 
Now a word about gifts. (4) Chinese people will often refuse a gift a number of times before finally accepting. Don't offer anything that's too expensive. Give similar gifts to people who are at the same level of importance. Wrap your gifts in red paper which is considered a lucky colour. (5) Chinese people will appreciate any famous brands of the country they're visiting.

Punctuality is very important. They expect people to arrive on time for a meeting. To arrive late shows a lack of respect.

'Sincerity' is highly valued by the Chinese.

As sentenças sublinhadas na fala de Catherine poderiam ser substituídas, sem perda de (força do) significado, respectivamente, por: (1) 'Your visitors appreciate this', (2) 'It is cheaper and the Chinese may trust a company member of staff more quickly, (3) They are eager to learn about life in your country and about its culture, (4) Chinese people often refuse a gift a number of times before finally accepting, (5) Chinese people appreciate any famous brands of the country they're visiting. Acreditamos, portanto, que o uso de 'will' se equivale ao uso do respectivos verbos no presente, pois o significado produzido é o mesmo.

Porém, encontramos afirmações do tipo categóricas (uso dos verbos no presente atemporal): '[...] business relationships with the Chinese are built on personal trust and respect', 'Punctuality is very important', 'They expect people to arrive on time for a meeting', 'To arrive late shows a lack of respect' e 'Sincerity' is highly valued by the Chinese.'

A presença de expressões imperativas, destacadas a seguir, também é significativa:

'Remember that status is important.'

'Make an effort to learn a few words in Chinese.'

'Be careful about topics for discussion at social events.'

'Don't embarrass visitors by introducing 'difficult' topics.'

'Don't offer anything that's too expensive.'

'Give similar gifts to people who are at the same level of importance.'

'Wrap your gifts in red paper.' 
As representações sobre a China fixam sentidos sobre essa cultura que é vista como uma unidade, dotada de aspectos imutáveis e previsíveis; ao interlocutor, basta compreender o modo de funcionamento aparentemente 'estável' dos aspectos culturais para ter sucesso nas negociações com essa cultura.

O modo como as culturas são representadas as torna passíveis de se submeterem a um código de conduta que, uma vez seguido, resultará no sucesso da interação, que também é vista como um processo mecânico que acontece sob condições de produção também homogêneas. Ou seja, o LDIN propõe que a língua, uma vez concebida como código, seja vista como objeto da comunicação, e faz com que os elementos de uma prática discursiva entre as culturas sejam vistos como um código.

A seguir, discutiremos como a transposição de uma notícia, apenas, é o bastante para promover um congelamento de sentidos sobre os países, fixando características sobre os mesmos e promovendo ainda marginalização e exaltação.

$\mathrm{O}$ artigo analisado (artigo K), com o título 'Sobre Celebridades, Caridade e Negócios ${ }^{54}$, traz como tema a prática do 'free trade' (ou 'comércio-livre'). llustrado no livro com uma foto de Bono com o secretário do tesouro americano em meio a crianças de Uganda (reproduzida a seguir). Trata-se da questão da importância da caridade ou misericórdia, 'cujos efeitos são sentidos tanto por aquele(s) que a recebe $(\mathrm{m})$ quanto por aquele(s) que a oferece $(\mathrm{m})$ '.

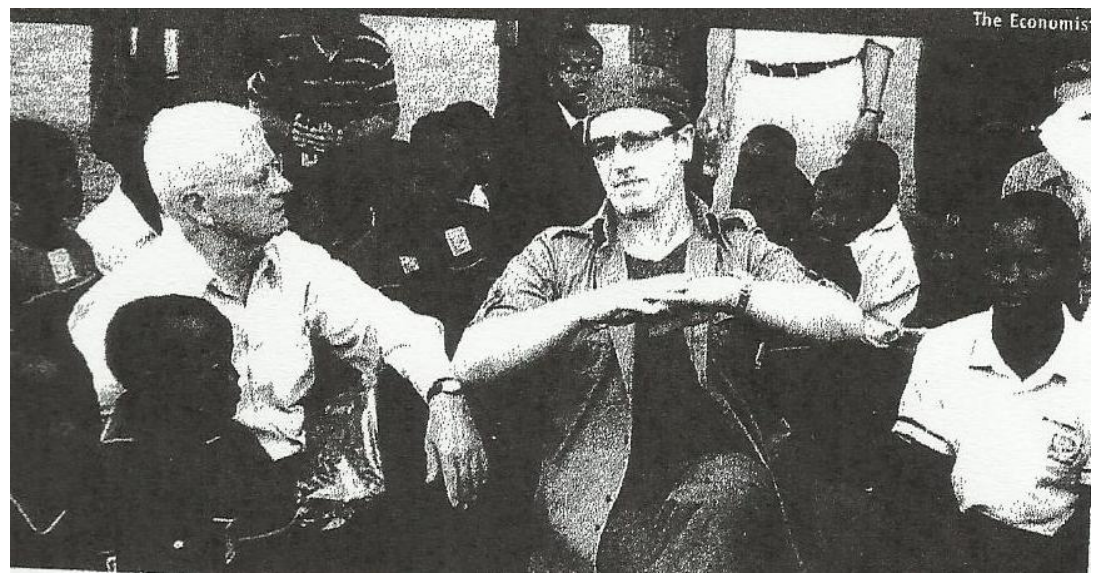

\footnotetext{
54 O artigo, na íntegra, está nos anexos.
} 
Um dos trechos do artigo discorre sobre a prática do "free-trade" entre a Inglaterra e a Uganda:

Growing flowers is hardwork, but no more so than subsistence farming, which is the alternative; and it pays better. Everyone benefits: Europeans get roses in winter and Ugandan rose-growers eat better and put their children through school

A avaliação das consequências dessa prática - cultivo de flores - tanto para os que vivem em Uganda quanto aos europeus é representada como: um ajuda o outro, de forma harmônica, sem conflitos, e somente há ganhos para ambos. O povo de Uganda é representado como beneficiário dessa prática, tanto quanto os europeus, como se essa relação de comércio ou troca trouxesse vantagens iguais às partes envolvidas. Apaga, assim, a dimensão sócio-histórica constituinte dessas práticas.

O foco central é a importância de 'fair trade' pois, de acordo com o artigo, essa prática proporciona melhores condições de vida aos países menos favorecidos e, consequentemente, possibilita o crescimento econômico. No artigo é descrito que o cantor irlandês Bono visita uma comunidade pobre em Uganda com o secretário do tesouro americano e esta cena é vista como nãofamiliar, pois de acordo com o texto, ministros de finanças norte-americanos raramente gastam seu tempo em favelas africanas e estrelas do rock raramente participam de discussões em alto nível sobre a economia do desenvolvimento.

'singer of Irish rock band U2'
'represents globalisation as its best'
voz do cantor, enquanto instância que enuncia, na primeira frase e o uso das aspas na segunda. Tem-se, portanto, um caso de afirmação, no sentido de legitimar sua opinião e sua atitude. O comentário do cantor é colocado em destaque, entre aspas, o que mostra que são suas as palavras, não do locutor do texto. Porém, logo após aparece a proposição 'Of course he is right'. É uma voz de opinião do locutor, que afirma concordar com a atitude de Bono.

A unidade em que $O$ artigo está inserido intitula-se 'Lobbies', que se refere a pressões por parte de algumas empresas sobre as atitudes do 
governo, visando à obtenção de interesses privados; como verbo, pode-se definir como 'to try to persuade (a politician, an official or an official group) that a particular thing should or should not happen, or that a law should be changed) ${ }^{55}$. Esta unidade pretende denunciar as más práticas que acontecem nas empresas ou por meio delas. Há uma ilustração presente na unidade, a seguir reproduzida, sobre a qual faremos algumas considerações:

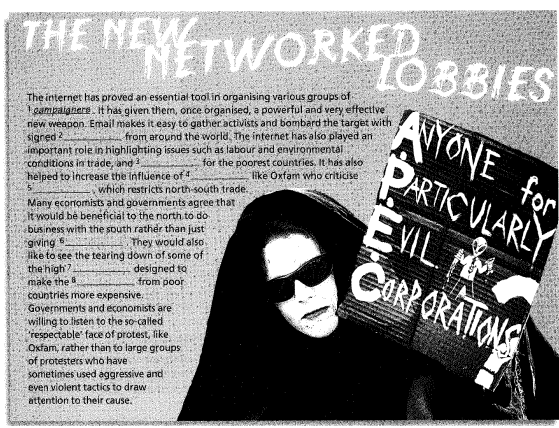

De acordo com KRESS e LEEUWEN (1999: 381), nas imagens em que os participantes retratados olham diretamente para o observador (interlocutor), há uma relação estabelecida entre eles em um nível imaginário; uma forma de contato que se firma. Os autores caracterizam esse tipo de imagem como uma 'demanda', pois esta consiste em fazer com que o observador entre em uma relação imaginária, baseada em uma exigência, sobre o que é representado na imagem. Na figura anterior, temos a imagem de uma pessoa que segura uma placa com as informações 'Anyone for particularly evil corporations?' Podemos concluir que a imagem exorta o leitor a se tornar um adepto da causa referida: unir-se contra a exploração praticada pelas empresas.

Ao final da leitura, temos um exercício que novamente exalta a cultura britânica ao reforçar sua atitude como benfeitora para os países pobres. Trataremos mais detalhadamente da questão da representação da identidade britânica na próxima seção.

A imagem que se cria é que não há diferenças culturais ou conflitos histórico-culturais. A própria justaposição das palavras no título do artigo 'Of celebrities, charity and trade' já antecipa uma visão romântica e ideal dos três elementos. E isso seria a definição de 'Finding a Voice': os ugandenses 'têm seu lugar', ou seja, podem contar com o mercado inglês, que proporciona àqueles um benefício. $O$ efeito de sentido que se cria, portanto, é que os

\footnotetext{
${ }^{55}$ Cambridge International Dictionary of English, 1996.
} 
britânicos somente beneficiam o povo de Uganda, uma vez que este tem mercado garantido para vender suas flores.

GUIMARÃES (1987: 120) enfatiza que o uso da conjunção adversativa 'but' faz com que se estabeleça entre o sujeito enunciador e seu interlocutor, um início de ponto de vista e um final, sendo que o final é mais forte, ou seja, possui maior força argumentativa. No caso, 'but no more so than subsistance farming', produz o efeito de sentido que trabalhar arduamente ainda não é a pior situação, mas sim viver daquilo que se planta ('subsistance farming'). 0 que essas formulações silenciam é o fato de que essa relação de troca não se restringe ao que fora definido. Apagam o lado negativo que essa prática pode trazer, naturalizando o sentido dos temas abordados, e de uma forma redutora, constroem uma relação harmônica entre as culturas.

Além disso, apagam sentidos da colonização britânica em Uganda e a luta política em torno de sua independência, em 1962. O discurso dilui, portanto, a dimensão política e histórica entre os dois países.

O exercício proposto para a atividade de leitura é completar os espaços em branco (que aqui estão sublinhados) do texto com frases (já inseridas), de acordo com o assunto dos parágrafos, como mostra a seguir

\section{Fair Trade}

\section{Of Celebrities, Charity and Trade}

\section{Charities are not yet free-traders, but some are halfway}

\section{there}

In the energy-sapping heat of Uganda, women bend double to grow flowers for export to Europe. According to Bono, singer of Irish rock band U2, this scene represents globalisation as its best.

$\mathrm{He}$ is right, of course. Growing flowers is hardwork, but no more so than subsistence farming, which is the alternative; and it pays better. Everyone benefits: Europeans get roses in winter and Ugandan rose-growers eat better and put their children through school. A number of organizations now recognize that trade between developed and less developed economies allows poorer countries to improve their economies. A number of charities have also noticed that north-south trade is not always exploitative. Oxfam has just released a fat report on trade, in which it denounces rich countries' tariff barriers against 
imports from poor countries, and their subsidies for farmers. Another leading charity has condemned northern protectionism.

Bono spent two weeks touring Africa with Paul O'Neill, the US Treasury Secretary. It was an odd spectacle. US finance ministers do not often spend time in African slums and rock stars rarely take part in high-level discussions about development economics. But the trip revealed a few things about the changing relationships between governments, charities and celebrities. Even if politicians in democracies don't have to do what the voters want, they generally do take their opinion seriously. So, if charities want them to be nice to Africa, they must persuade voters to demand this. And to attract voters' attention, it helps to have a few celebrities.

This tactic succeeded spectacularly during the 'Jubilee 2000' campaign for debt relief. By using Bono and other famous people to draw attention to the problem, campaigners persuaded a record $25 \mathrm{~m}$ people to sign their petition, which then pushed rich country governments into cancelling a large part of poor-country debt. Europeans pay twice as much for a basket of groceries as do more liberal New Zealanders. Mr O'Neill used to argue that aid was wasteful and created dependence; now he says that rich countries should give grants, not loans.

Africa's share of world trade is a tiny two per cent, but the continent's exports are still ten times what it receives in aid. A small increase in trade would make far more difference in aid. Bono is not very clear about how this could be done, but DATA, the lobbying group he fronts, insists the rich world must lift quotas and duties on African exports, and cut subsidies that harm African growers.

That would be helpful. But there is also a selfish case for ending protection: that it would save taxpayers a fortune and make their food cheaper. Similar tactics helped the Bush administration to take a fresh look at foreign aid. The farm that George Bush signed is expected to cost the average US household $\$ 4,377$ over the next decade. Poor Americans will suffer most, because they spend the largest share of their incomes on food. This continues partly because voters are unaware of it. "Fair trade" charities and their celebrities could surely stir a lot of people to angry protest over farm subsidies if 
they tried. But being charitable people they prefer to make liberalisation sound the sacrifice it is not.

As atividades propostas pelos artigos analisados, portanto, têm em comum a busca em fechar sentidos para as representações dos países. Fixam características destes, produzindo sentidos únicos e, assim, neutralizam as diferenças existentes entre as culturas. O modo de funcionamento dessas representações favorece certas interpretações e evita outras, e a interpretação desejada por eles é vista, pelos usuários do livro, como a 'verdade', ou seja, como a leitura única e certa.

Entretanto, as culturas não existem enquanto unidades homogêneas. CORACINI e PERUCHI (2003: 364) afirmam que não é possível falar da cultura de uma nação, uma vez que muitos dos valores, hábitos, crenças se modificam em contato com outros povos, outras nações, outros grupos sociais. Porém, essa característica não é trabalhada no LDIN, pois o que fica marcado são identidades fixas ou características estáveis atribuídas às culturas.

Essa característica não é exclusiva do livro didático de inglês para negócios. Em geral, livros didáticos são vistos como dotados de um discurso de verdade, conforme GRIGOLETTO (1999: 68), que afirma que aos alunos cabe apenas reconhecer e consumir os sentidos produzidos pelos livros didáticos. A autora ainda complementa:
A estrutura cristalizada do LD que, já o dissemos, contribui para corroborá-lo como um discurso de verdade, revela o seu caráter massificante, ao negar espaço para a individualidade do aluno, abafando a expressão da voz de cada um. (op. cit., p. 69)

Ou seja, ao apenas reproduzir um sentido pré-definido, os exercícios do LDIN não oferecem ao aluno a oportunidade de discutir ou construir um significado diferente daquele impresso pelo livro. Ou seja, silencia o aluno pelo 'congelamento' da interpretação:

No movimento de constituição dos sentidos, que passa sempre pelo dizer e pelo silenciar, um sentido que se fixa pelo dizer silencia outros sentidos possíveis, ainda que ilusoriamente. (idem, 2002, p. 112)

O sentido de silenciamento que utilizamos não é o silêncio que se refere à ausência de palavras, e sim ao silêncio fundador, que é o princípio de toda significação. Ao dizer algo, não dizemos outra coisa: é condição da língua. Só é 
possível produzir um sentido se apagarem-se os outros. Senão, não se tem a ilusão da unidade necessária (condição) na própria produção dos sentidos. Segundo ORLANDI (2007: 68), O silêncio é entendido "como sentido, como história, como matéria significante. O silêncio de que falamos é o que instala o limiar do sentido".

O limite de um sentido consiste, enquanto possibilidade, no início do outro. O limiar marca a potencialidade de uma nova interpretação; se o exercício de leitura (e seu exercício correspondente) para no limiar do silêncio, ele não permite passar desse limiar e confere um sentido sempre-já determinado pela formação discursiva que o delimita, aquela que está em funcionamento no processo de leitura.

O aluno constitui-se, assim, a partir da completude do sentido, que é pressuposto pela $A D$, pois é o que the confere o sentimento de identidade, assim como, paralelamente, o efeito de literalidade (unidade) no domínio do sentido: o sujeito se lança no seu sentido (paradoxalmente universal), o que the dá o sentimento de que esse sentido é uno (ORLANDI: 2007, p. 79). É dessa forma que o material didático constitui-se como fonte importante com relação à formação do imaginário do aluno sobre culturas e povos. A ele é interditada a chance de lançar mão dos sentidos que já o constituem para que possa contribuir na interpretação. Há um silêncio dos sentidos, portanto.

Veremos como as culturas são representadas na dualidade bem $\mathrm{X}$ mal quando se trata dos norte-americanos e dos britânicos na seção a seguir.

\section{2- Dicotomia bem $x$ mal: as representações hegemônicas das culturas britânica e americana}

Tomar a língua na sua opacidade implica considerá-la como nãotransparente e assim compreender que os sentidos não são apreendidos na superficialidade lingüística, mas são construídos a partir de sua exterioridade. Para a AD, os sentidos são construídos na sua relação com a história.

As culturas no LDIN são faladas através do discurso do mundo dos negócios, que abarca tanto o discurso sobre empresas públicas, privadas, bem como a atuação dos governos dos países que são tema dos textos no LDIN. As 
representações são feitas tendo como eixo norteador a atuação das empresas, suas condutas e a sua repercussão na mídia.

Uma das formas em que a metáfora funciona no LDIN se refere ao modo de dizer qualificador com relação à representação dos britânicos e dos norteamericanos: os primeiros são exemplos de qualificações positivas acerca dessas práticas: honestidade, transparência, funcionalidade, satisfação. Já aos norte-americanos são atribuídos adjetivos e expressões negativas, como corrupção, insatisfação, medo, ganância, como veremos adiante. Assim, é na tensão entre caracterizações positivas e negativas que se dá a representação dos países em questão. Essas culturas são representadas como dotadas de formas de agir que podem ser admiráveis ou desprezíveis, e que causam, igualmente, consequências condizentes. Trabalharemos com o conceito de enunciado segundo FOUCAULT (1969), sobre o qual discute DELEUZE (1988: 29):

Os enunciados não são palavras, frases ou proposições, mas formações que apenas se destacam de seus corpus quando os sujeitos da frase, os objetos da proposição, os significados das palavras mudam de natureza, tomando o lugar no "diz-se", distribuindo-se, dispersando-se na espessura da linguagem. [...] a linguagem só agrega a um corpus para ser um meio de distribuição ou de dispersão de enunciados, a regra de uma "família" naturalmente dispersada.

Discutiremos como as formulações remetem a dizeres sobre os países em questão, reforçando o imaginário que se tem sobre eles, e assim produzindo conhecimento. Mais uma vez, é importante ressaltar a importância da legitimação do discurso nessas representações que podem ser superficialmente descritas como neutras, livres de poder e ideologia. Porém, a análise discursiva busca tratar da produção das formulações e assim mostrar seu funcionamento ideológico.

\subsection{1- A representação dos britânicos}

Vejamos a exaltação da cultura britânica. Podemos observar algumas regularidades nas representações relacionadas aos britânicos, ao analisarmos alguns excertos: 
Excerto 12- Artigo (K) de título 'Nobody does it better ${ }^{\text {'56, }}$, sobre o sucesso dos filmes de James Bond.

The James Bond movies are the longest-running, highest grossing film series in history. Currently turnover stands at over $\$ 6$ billion. In fact, the combined earnings of the Star Wars and Star Trek series and the most successful single film ever, Gone with the Wind, still fall $\$ 750$ million short of Bond at the box office.

Excerto 13 - Artigo (L) que trata de uma mercearia japonesa, Zen Nippon $^{57}$, que é descrita como seguidora dos modelos da rede de supermercado britânica Tesco.

One of its models is Tesco, Britain's biggest supermarket chain-which, ironically, is often accused of fatally undercutting independent local shops on its home turf. In 2009 Zen Nippon's president, Mitsuhiro Saito, sent six employees to Oxford to learn about Tesco's loyalty-card scheme. They were interested in how the firm uses data derived from the cards to understand not only what people are buying, but also how changes in lifestyle can affect shopping habits.

A comparação é um recurso utilizado em ambos os excertos e, através dela, os britânicos são representados como portadores de posição de prestígio.

In fact, the combined earnings of the Star Wars and Star Trek series and the most successful single film ever, Gone with the Wind, still fall $\$ 750$ million short of Bond at the box office.

\footnotetext{
${ }^{56} \mathrm{O}$ artigo completo está nos anexos.

${ }^{57}$ Disponível em <http://www.pearsonlongman.com/intelligent_business/teachers_resource.html> Acesso em: 19 jul. 2012.
} 
No excerto 12, filmes são postos lado a lado e a supremacia britânica é representada através da comparação entre o faturamento de bilheteria das três séries americanas (Star Wars, Star Trek e Gone with the Wind) e a da série britânica. Ou seja, a vantagem em termos de bilheteria é pautada pela remissão a produções americanas, inclusive à maior delas, 'Gone with the Wind'. O uso do superlativo também é recorrente e funciona de modo a elevar a importância das práticas britânicas ('longest-running', 'highest grossing', 'most successful', 'biggest'), ao provocar efeito de superioridade.

Ainda no excerto 12, um outro elemento que funciona como reforçador da identidade britânica como superior é o uso de números que remetem a lucros, vendas em bilheterias, enfim, números financeiros. BRANDÃO (1998), ao analisar a argumentação, fala da 'ideologia da transparência', que é a forma textual em que se tenta apagar quaisquer traços de subjetividade do locutor, ao deixar claro para o leitor que a notícia se confirma através de números, ou seja, um parâmetro das ciências exatas: 'os fatos começam a falar por si mesmos na inquestionabilidade dos números (op. cit.: 57) e apaga-se o ideológico que está presente também na constituição desses sentidos. Assim, causam uma visão realista e, portanto, objetiva da cultura.

No excerto 13, a comparação é utilizada novamente para falar das performances das empresas britânicas (que se sobressaem diante de outras e por isso servem de modelo para essas): 'One of its models is Tesco, Britain's biggest supermarket chain'. Ainda nesse excerto, o sintagma 'modelo' funciona como pré-construído no momento da enunciação. Um modelo se constitui como algo benéfico e que serve para exercer influência positiva em algo que não está num patamar tão alto. Ou seja, os britânicos podem transferir seu expertise à empresa japonesa para que esta aperfeiçoe suas vendas. A importância do país é elevada, e ele é representado como ideal, próspero e como solução para os problemas daqueles menos experientes.

O enunciado do interdiscurso que está presente nessas formulações é 'o britânico é superior'. Sua predicação como tal é a região do interdiscurso que o 
corpus sob análise delimita como seu memorável, ou seja, como aquilo que faz parte da história e aparece nos dizeres, mobilizando sentidos.

O efeito de pré-construído ocorre, portanto, pelo uso do superlativo, que eleva a cultura britânica, e o comparativo nas formulações, que coloca frente a frente os países, mas que favorece, ou atribui a parte positiva da comparação, aos britânicos.

A seguir, faremos considerações sobre como são fixadas noções sobre a superioridade da cultura britânica através da análise de exercícios propostos a partir da leitura do artigo acerca de James Bond. Segundo o manual do professor, o objetivo da seção é o seguinte:

This section gives students the opportunity to use the language and skills they have learnt in this unit in a simulated decision-making meeting.

Os objetivos gramatical e lexical da unidade são encontrados no início desta, no livro do professor:

The grammatical focus is on conditionals and the lexical focus is on collocations relating to the market place.

Não se faz referência ou não se trabalha, portanto, o conteúdo do texto em seu caráter ideológico, ou seja, deixa-se claro que o texto de leitura de Bond será utilizado para fins de prática de gramática e léxico, aspectos formais da língua, ou seja, língua como instrumento de comunicação.

Após essa informação, temos o trecho que sugere um exercício de warm-up:

Warm up: Explain to students that they are going to make a decision regarding the actor who will play James Bond in the next Bond film. Find out how many of them have seen a Bond film, whether they have a favourite one and which of 
the actors who have already played Bond (Sean Connery, Roger Moore, Timothy Dalton, Pierce Brosnan) they liked best in the role.

Primeiro ponto: o exercício de leitura não deixa uma abertura para o questionamento sobre a pertinência das qualidades atribuídas ao personagem Bond. Elas são afirmadas no exercício que, imediatamente, segue à leitura:

According to the article, what are the main reasons for the success of the Bond films? Tick the correct answers:

The special effects ( )

The sex and violence ( )

The 007 brand name $(X)$

The actors playing Bond $(X)$

The novels the films are based on ( )

The Bond character $(\mathrm{X})^{58}$

Veremos que as características marcadas anteriormente serão mencionadas nas falas dos atores em potencial para o próximo filme de Bond. Portanto, parte-se delas para quaisquer outras tarefas relacionadas à escolha do próximo Bond.

Quanto a essas tarefas, há duas: decidir qual ator (dos quatro listados no exercício 3 , analisado a seguir) seria o mais apropriado para ser o próximo Bond ao tomar como base as características (de superioridade) já atribuídas ao personagem e analisadas acima, através do comparativo e do superlativo. Além disso, escolher, dentre os atores que já representaram o personagem, qual foi o melhor. Ou seja, já se pressupõe que todos esses que já fizeram Bond foram, pelo menos, bons atores; cabe ao aluno decidir qual foi o melhor.

A instrução reproduzida a seguir, extraída do livro do professor, até propõe uma discussão, mas de forma fraca e não-obrigatória.

\footnotetext{
${ }^{58}$ Segundo o livro do professor, as alternativas marcadas são as corretas.
} 
You might like to ask students to say whether or not they agree with the analysis in the text of the success of the Bond films.

Quanto à escolha do próximo Bond, o exercício 3 traz perfis de quatro atores, dentre os quais os alunos devem escolher aquele que melhor representaria Bond, depois de terem feito o exercício de listar quais características o próximo Bond deve ter. Alguns pontos desses perfis merecem destaque:

Peter Aston-Sharpe: 43, English, has starred in two fairly-low budget, but successful, British films.

Jon McCabe: 31, Scottish, very little acting, but his recent supporting role in a London gangster movie won praise on both sides of the Atlantic.

Sam Landon: 39, American, has starred in several high-action blockbusters, although his last film, a comedy, lost money.

Charles Fox: 35, English, 'Britain's favourite sex symbol'.

Após esse exercício, há um exercício de compreensão oral organizado com o depoimento desses quatro atores falando sobre eles mesmos, como personagens que representam Bond.

Destacamos, dos scripts originais, as perguntas do entrevistador (A) e as partes das respostas mais interessantes dos atores (B, C, D, E e F) para a análise:

Interview 1

A: So, Peter, how do you see the Bond role?

B: 'I think too many actors want to play Bond... an obvious superhero... but above all he's someone outside the ordinary world.'

Interview 2 
A: Well, Sam, you're an American. Is that going to be a problem for you playing Bond?

C: 'No, I've played Brits before and my English accent's OK. I don't see why Bond can't be an American, or at least a Canadian.'

\section{Interview 3}

A: Now, Jon, how do you see yourself playing the part of Bond?

D: Well, firstly, I think over the years Bond has lost some of his danger. And I'd like to change that. He has a license to kill. He's not just a pretty face. He's a dangerous man.

\section{Interview 4}

A: Charles, you've wanted the Bond part for a long time. How would you play him?

E: l'd like to see Bond return to the old style of those early films. I think Bond has become too techno these days. And it's difficult to compete with films like Star Wars and The Matrix on special effects. Bond shouldn't take himself too seriously, but he shouldn't be a joke either. Bond -the real Bond -belongs to the 1960s, a more optimistic, less cynical age. My Bond would be ...er... traditional, intelligent, charming. He'd drive his old Aston Martin, not a BMW! He'd keep his old-fashioned values, but in a modern world of real dangers. Bond is something unique. A British institution. He shoudn't be modernised.

Nos excertos, encontram-se destacadas em negrito as formulações que afirmam a supremacia britânica. Na entrevista 1, encontramos: 'above all he's someone outside the ordinary world", que eleva o personagem britânico, que não se compara a nenhum deste mundo.

Na entrevista 2, a superioridade britânica é afirmada através da língua; 0 ator diz ser elegível para o papel de Bond uma vez que seu sotaque britânico é bom e que havia feito filmes britânicos. Para ser bom ator, tem que copiar ou imitar bem o sotaque britânico. 
Na entrevista 3, há a reafirmação das características de Bond que, se foram perdidas, devem ser resgatadas. $O$ personagem deve manter sua imagem.

Já na entrevista 4, novamente se afirma a necessidade de Bond retornar ao que era antes e não ceder à tecnologia dos efeitos especiais, através das formulações 'the real Bond', 'he'd keep his old-fashioned values'. Há uma associação entre filme de ficção científica a uma 'piada', no sintagma 'joke'. Bond, ao contrário, deve manter sua tradição (tal como se afirma na entrevista 3), seu conservadorismo, como a Inglaterra, já que é uma instituição britânica e não deve ser modernizado.

Vejamos um outro exemplo de exaltação da Grã-Bretanha. Como mostra a seção 'Background'59, reproduzida a seguir, o 'Case Study' em que está inserida apresenta a seguinte situação: o 'Auric Bank' está em processo de rever suas atitudes para proporcionar a seus clientes um ótimo serviço a preços competitivos.

\section{Background}

'We constantly review our business in order to provide customers with excellent service at competitive prices. As part of our major reorganisation, we've been looking at the cost of customer services. We have a range of options. We can make changes in-house, outsource call centres to areas within the UK or outsourse off-shore to low-cost countries such as India.'

Graham Hammond, Chief Executive, Auric Bank.

A parte sublinhada trata das mudanças que podem ocorrer: fazer modificações no próprio local de instalação do banco, terceirizar call-centres para áreas dentro da Grã-Bretanha ou terceirizar para fora do território, como em países de baixo custo, tais como a Índia.

\footnotetext{
${ }^{59}$ Market Leader Intermediate Coursebook, 2006, p. 28.
} 
À primeira vista, os alunos estão diante de um exercício que oferece liberdade de escolha. Porém, no livro do professor, encontramos a seguinte informação:

If there is time and interest, have a general class discussion about the merits of each solution. Point out that many British companies that have outsourced to India are having second thoughts, and are bringing back their operations to the UK, because of problems of communication, local knowledge and image with customers about not using British workers. ${ }^{60}$

Ou seja, ao mesmo tempo em que é dada uma opção ao aluno, existe uma injunção à não-escolha das opções que não sejam a Grã-Bretanha; no caso, as opções 2, 3 e 4, como vemos a seguir.

Option 2: Outsource the call centres to a company based in South Africa Use resource Plc, a Cape Town firm. They can set up the call centres in Cape Town and run them.

-The firm has an excellent reputation for reliability and good service -It has a lot experience in running centres

Cost of the contract with Resource Plc to run the call centres for the next five years: £8 million.

Option 3: Outsource the call centres to a company based in Scotland Use Orion Plc, a Scottish firm

The firm is new; its managers are young

- It has several contract with big companies

- It is experienced in running call centres

- Some customers have complained in newspapers that the lines are always busy

${ }^{60}$ Market Leader Intermediate. Teacher's Resource Book. 2007, p. 31 
Cost of the contract with Orion Plc to run the call centres for the next five years: $£ 10$ million.

Option 4: Outsource the call centres to a company based in India

Use X-source India, a company based in Bangalore.

- $\quad X$-source India is expanding fast

- It has contracts with several large US companies

- It has no problems hiring staff and its costs are slow

Cost of the contract with X-source India to run the call centres for the next five years: £5.5 million.

Além disso, podemos notar que todas as opções, a partir da segunda, têm seus contratos mais caros do que a opção de permanecer na GrãBretanha. A que tem o valor mais baixo, depois da opção 1, é a Índia, porém é essa opção que sugerida que se descarte. A opção da Inglaterra é a primeira, e a que se considera a de melhor escolha:

Option 1: Keep the call centres in-house.

Keep the call centres in their present locations but try to reduce costs by:

- Using more part-time employees

- Reducing the hours of business of the centres

- Increasing the targets for the number of calls handled per hour

Estimated cost of running the centres for the next five years: /16 million. -

Estimated savings by introducing changes above: / 3 million.

Esses exemplos fixam noções sobre a Inglaterra, atribuindo-lhe características estáveis, que a representam de uma maneira específica e apaga outras possibilidades de leitura. O LDIN busca, portanto, congelar ou imprimir sentidos específicos, estabilizar lugares de significação.

HALL (1992: 51), ao falar da cultura nacional como fonte de significados, afirma que são construídas identidades, pelas estórias que são contadas sobre a nação, criando imagens com as quais nos identificamos. Por isso, para o 
autor, não há como se falar em uma unidade quando se trata da identidade cultural, pois esta está sempre sendo formada, em processo contínuo, incompleto, fruto de uma construção.

Assim, a cultura britânica não consiste de uma parceria igual entre as culturas componentes do Reino Unido, mas da hegemonia efetiva da cultura "inglesa", localizada no sul, que se representa a si própria como a cultura britânica essencial, acima das culturas escocesas, galesas e irlandesas e, na verdade, acima de outras culturas regionais. (idem, op. cit: p. 60)

Acrescenta, ainda, que seria mais correto pensar as culturas nacionais como constituindo um dispositivo discursivo que representa a diferença como unidade ou identidade. Ou seja, é da ordem de uma construção discursiva a 'unidade' pressuposta na representação das culturas (op. cit., p. 62):

Elas são atravessadas por profundas divisões e diferenças internas, sendo "unificadas" apenas através do exercício de diferentes formas do poder cultural. Entretanto [...], as identidades nacionais continuam a ser representadas como unificadas.

Esse poder cultural que unifica as culturas remete às formas de poder em jogo nos discursos de representação das culturas, ou seja, nos discursos que falam das culturas, que privilegiam algumas e marginalizam outras, mas unificam as representações.

\subsection{2- A representação dos norte-americanos}

Notamos que a identidade americana é representada sob, pelo menos, três aspectos:

- $\quad$ como um país que quer impor mundialmente sua cultura;

- $\quad$ como um país ganancioso;

- $\quad$ como um país que explora sua mão de obra.

Primeiramente, analisaremos dois excertos do norte-americano como uma cultura que visa impor seu modo de vida mundialmente:

Excerto $14^{61}$

\footnotetext{
${ }^{61}$ Este excerto faz parte do primeiro artigo analisado no capítulo 2 (artigo A).
} 
(...) Personally, however, I would be more interested in reading its cost/benefit analysis of the social and cultural questions. Does globalisation, for example, increase our access to the art or are we suffering from a global pop culture easily sold anywhere? Does globalization enable more people to experience the surprises or pleasures of cultural diversity or is it leading to the elimination of differences and the mixing of national and local cultures, into a global, mainly American, stew? Are our lives made more interesting and exciting by globalisation's destruction of old traditions and communities or are we made more miserable by the loss of cultural individuality that gives structure to our lives?

Excerto $15^{62}$

The global village is a product of the media. CNN World Report has 130 reporters covering $\mathbf{2 0 0}$ different countries 'the American Way'. Satellites do not respect national borders. MTV has gone where the CIA never could -into 400 million homes globally. Its influence on young consumers is huge. MTV's Bill Roedy says 'We're always trying to fight the stereotype that MTV is importing American Culture'. At the same time, he adds: 'We want MTV in every home.' Polish president, Aleksandr Kwasniewski, sums it up: 'We have to realize that MTV is more powerful than NATO.

No excerto 14, é afirmado que o país exporta sua cultura, invade outros países com sua produção cultural, e fica implícito que o ideal seria um tipo de cultura que não exercesse tamanho poder pois, assim, seria mantida a individualidade do outro e faria permanecer a 'estrutura que dá sustentação à nossa vida'. O locutor, através do pronome 'l' afirma sua opinião pessoal, através do advérbio 'personally', e fala em nome de um 'nós' que, novamente, pode referir-se ao locutor e ao interlocutor (nós inclusivo) ou a um 'nós' jornalistas do Financial Times. Os períodos compostos com perguntas, no tempo presente, têm a função de fazer com que o leitor concorde sempre com o segundo período, pois atribuem elementos negativos à globalização no primeiro e positivos ao segundo.

62 In Company Intermediate Teacher's Book, 2002, p. 73. 
A idéia que se fixa, no segundo excerto (15), é a de que os Estados Unidos detêm um vasto poderio e que este é maior que as maiores empresas ou organizações do mundo (NATO e CIA). Um recurso utilizado para dar este efeito é, novamente, a comparação, como mostramos a seguir:

'MTV is more powerful than NATO' e 'MTV has gone where the CIA never could'

O uso da expressão 'at the same time' indica um paradoxo: ao mesmo tempo em que o autor cita que o chefe da MTV quer evitar que a imagem da TV se associe à cultura dos EUA, aponta que o mesmo quer que a MTV esteja em todas as casas.

CORACINI e PERUCHI (2003: 363) afirmam que a globalização provoca o temor da perda das identidades e o da consequente 'uniformização cultural (ou aculturação imposta pelas grandes potências mundiais, sobretudo os EUA)'. Os excertos mencionados ilustram essa afirmação e a potência mundial representada é a dos Estados Unidos.

Vale ressaltar que o excerto 14 ainda constrói uma ideia de globalização como algo somente benéfico, que traria apenas aspectos positivos (que chamaremos de $\mathrm{A}, \mathrm{B}$ e $\mathrm{C}$ ), como vemos a seguir:

Does globalisation, for example, (A) increase our access to the art or are we suffering from a global pop culture easily sold anywhere?

Does globalization (B) enable more people to experience the surprises or pleasures of cultural diversity or is it leading to the elimination of differences and the mixing of national and local cultures, into a global, mainly American, stew?

(C) Are our lives made more interesting and exciting by globalisation's destruction of old traditions and communities or are we made more 
miserable by the loss of cultural individuality that gives structure to our lives? ${ }^{63}$

Em A, ela aumentaria nosso acesso às artes, em B proporcionaria mais pessoas a experienciarem as supresas e prazeres da diversidade cultural. Já em C, nossas vidas seriam mais interessantes e estimulantes. E os Estados Unidos, nessa descrição, funcionam como um destruidor dessas vantagens ou benefícios da globalização. Novamente, há a neutralização de sentidos, que provoca o silenciamento de outros, como por exemplo, o da própria perda de identidade mencionada na citação acima ou da globalização como algo apenas benéfico.

A segunda representação (artigo $N$ ) vê os EUA como um país ganancioso que não mede esforços para conseguir dinheiro ou influência mundial:

Excerto $16^{64}$

But what the stock market investors didn't know was that the company [Enron] had been cooking the books, inventing partner companies that didn't really exist to hide huge debts and even huger losses. In 2000 Enron reported a net income of $\$ 979$ million, even though it had actually only earned $\$ 42$ million. And by employing some of the most brilliant creative accounting ever $(\ldots)$

O tema do escândalo envolvendo a empresa Enron é representado através do uso de figuras de linguagem, como a metáfora, no sintagma 'cooking the books'. Há também o uso da ironia, em 'brilliant creative accounting'. $\mathrm{O}$ uso das figuras de linguagem pode sugerir que não se quer

${ }^{63}$ Market Leader Intermediate. Teacher's Resource Book, 2007, p. 164.

${ }^{64} \mathrm{O}$ artigo na íntegra está nos anexos. 
fazer as considerações sobre os Estados Unidos de maneira direta. Prefere-se camuflar o sentido por meio das figuras de linguagem. Com relação aos britânicos, como vimos, a representação é feita de forma direta ${ }^{65}$.

\section{Excerto $17^{66}$}

America will certainly change under Mr Obama; the world of extraordinary rendition and licensed torture should thankfully soon be gone. But America will, as it must, continue to put its own interests, and those of its allies, first. Withdrawing from Iraq will be harder than Mr Obama's supporters hope; the war in Afghanistan will demand more sacrifices from Americans and Europeans than he has yet prepared them for. The problems of the Middle East will hardly be solved overnight. Getting a climate-change bill through Congress will be hard. The next ten weeks give Mr Obama a chance to recalibrate the rest of the world's hopes.

\section{Hard times and a bleak House}

With such a great victory come unreasonably great expectations ${ }^{67}$.

O sintagma "Hard times" remete o leitor ao romance do autor britânico Charles Dickens, de mesmo nome. Uma das críticas desse autor, nessa obra, refere-se às mudanças ocorridas na Inglaterra vitoriana com relação ao capitalismo e a consequente exclusão social advinda com seu crescimento. Vitimizados pelo processo de modernização da Europa, os ingleses se viram excluídos na sociedade, em situações de exploração extremas.

\footnotetext{
${ }^{65}$ A referência a Bond como 'outside the ordinary world' poderia ser classificada como indireta, mas Bond é um personagem fictício. A linguagem indireta com relação aos Estados Unidos é utilizada para fatos verídicos (eleição de Obama, fraude na empresa Enron).

${ }^{66}$ Disponível em:

<http://www.pearsonlongman.com/intelligent_business/images/teachers_resourse/EW131108Obama.pdf> Acesso em 19 jul.2012

${ }^{67}$ Disponível em

<http://www.pearsonlongman.com/intelligent_business/teachers_resource.html>
}

Acesso em: 19 jul. 2012. 
De modo análogo, o sintagma 'Bleak House' pode sugerir uma comparação com 'White House': o artigo enfatiza que o novo presidente dos Estados Unidos enfrentará diversos problemas, ou seja, Obama terá situações complexas a resolver; o termo 'bleak' pode estar relacionado a lugar sombrio, escuro, perigoso, misterioso, apontando para uma comparação à conjuntura que o presidente está inserido. Ademais, pode também estar relacionado ao livro de Charles Dickens, de mesmo nome. A história, contada por meio de uma linguagem obscura e pautada em mistério, apresenta um panorama da sociedade inglesa do século XIX.

O sentido desse discurso perpassa o artigo, já que também menciona a ocorrência de acontecimentos negativos advindos das práticas econômicas e políticas dos EUA, através dos sintagmas 'rendition' (transferência ilegal de uma pessoa para outro país) e 'torture'. O artigo remete este período ao do governo de Bush através da oração 'under George Bush America's international standing has sunk to awful lows', referindo-se, portanto, a esse período como não glorioso na história do país. Porém, com a vitória de Obama como presidente, o país pode chegar a melhorar, porém ele deve usar seu poder sabiamente, o que fica marcado pelo título do artigo: 'Barack Obama has won a famous victory. Now he must use it wisely'. Se o presidente-eleito conseguir usar da inteligência para gerir o país, a situação deste vai melhorar, e haverá um 'final feliz'.

O romance Great Expectations, também de Dickens, traz como enredo o seguinte: o personagem principal da obra, Pip, após passar por inúmeras decepções e sofrimentos, não só na vida amorosa como também profissional, consegue terminar sua vida ao lado daquela que amou por toda a vida, Estella. A menção ao livro pode significar uma referência ao governo de Obama já que o artigo afirma que um futuro melhor está por vir para os Estados Unidos, a partir de seu governo.

Há, portanto, uma tensão no romance Great Expectations, que culmina numa solução, estrutura semelhante à do artigo, que apresenta a situação anterior a Obama, problemática, e vislumbra um bom futuro, depois de 
sua eleição como presidente, que promete ser a mudança de que o país precisa.

Nos artigos que se referem ao britânico, não há, normalmente, o uso de figuras de linguagem. Como dissemos, o uso deste tipo de linguagem nos artigos que tratam dos EUA tem por objetivo não dizer, numa linguagem direta, o que se quer representar. Daí o uso de metáforas, ironias, remissões.

A última representação analisada (e que sugere uma consequência da segunda representação) pode ser ilustrada com um exercício de compreensão oral com três falas acerca da injustiça praticada pelas empresas americanas para com seus afiliados, sejam fornecedores ou funcionários.

\section{Excerto 18}

I decided to join Global Exchange in their street protests because I believe we can force people to change their actions by demonstrating peacefully. You can draw their attention to the harm they may be doing and the good they could do if they changed policy, I mean, look at Starbucks. We believe that our peaceful demos outside their cafés influenced their decision to make fair trade agreements with their coffee suppliers. That guarantees coffee growers a reasonable price for their coffee and avoids unfair exploitation of coffee farmers.

O excerto refere-se à instituição Global Exchange, que é uma organização internacional norte-americana de direitos humanos dedicada a promover justiça social, econômica e ambiental no mundo; o locutor, em primeira pessoa, defende que as pessoas façam parte da entidade para promover a igualdade mundial. Denuncia, portanto, condições desumanas de trabalho impostas por empresas norte-americanas. 
Our lobby group really started to effect change when we joined up with UNITE, the textile workers' union, as well as some other pressure groups, to take some of the powerful clothes companies such as Gap and Calvin Klein to court. It was wonderful when most of them decided to do something about the sweatshop working conditions and poor salaries of their employees in the third world.

O locutor do excerto anterior é porta-voz de um 'nós', através do pronome possessivo 'our'. As empresas americanas Gap e Calvin Klein são o alvo do ataque. A acusação é que essas empresas, entre outras, oferecem condições desumanas de trabalho e ainda a baixíssimos salários. Podemos afirmar que elas trazem à memória o discurso imperialista sobre os Estados Unidos.

Percebemos nos excertos como se dá a construção da identidade norteamericana em "global pop culture easily sold everywhere" (excerto 14), "we want MTV in every home" (excerto 15), "cooking the books" e "brilliant creative accounting" (excerto 16), "hard times and a bleak house" (excerto 17) e "to take some of the powerful clothes companies such as Gap and Calvin Klein to court" (excerto 19). O efeito de pré-construído se dá pelas expressões destacadas dos excertos; a partir das proposições, notamos que a representação dos Estados Unidos é feita de maneira totalizante e reducionista, fechando sentidos com relação à representação deste país.

Um dos exercícios da unidade em que se encontram os excertos dessa última representação está reproduzido abaixo:

Look at the statements from a UK charity, which donates computers to children in poor countries throughout the world and choose the best option to complete the sentences.

There are many UK charities that provide computers to poor children in this country, so we feel we worry about these children.
a) ought to
b) need to
c) don't have to 
We feel that we concentrate our efforts in Africa.
a) must
b) needn't
c) mustn't

We realise that we just send computers to companies where there are no technology teachers.
a) should
b) shouldn't
c) needn't

The children learn to use them really as well.
a) shouldn't
b) need to
c) mustn't

Therefore, we send teachers to some developing countries.
a)have to
b) don't need to
c)shouldn't

If people wish to learn more about us, they visit our website.
a) must
b) ought to
c) have to

A unidade onde o exercício está inserido, a mesma em que se encontra o excerto sobre os ugandenses, analisada na seção 3.1, trata dos verbos modais de obrigação e necessidade (should, must, ought to). No exercício anterior, a proposta é que sejam praticados esses modais. Porém, o que fica silenciado é que o discurso da benevolência britânica perpassa o material, ou seja, frente a tantas más ações causadas pelos americanos, os britânicos são os salvadores, que trazem soluções.

Através das proposições, temos a remissão a um enunciado do interdiscurso, que funciona como pré-construído: "os Estados Unidos exercem o imperialismo e a supremacia por todo o planeta". Podemos afirmar que o discurso do LDIN sobre os Estados Unidos se dá por um modo de dizer 'informativo-qualificador', que através da adaptação dos textos jornalísticos da mídia de grande abrangência, representa o britânico e o norte-americano de maneira a produzir efeitos específicos sobre estes povos.

O norte-americano é colocado em um patamar de não-prestígio: tomado em seu âmbito cultural, corporativo ou político, ele é construído como um povo dotado de atitudes politicamente equivocadas, excessivas e gananciosas.

De fato, as representações analisadas, tanto acerca dos britânicos como dos americanos, reforçam e favorecem a noção de identidade como unidade, 
ou seja, como sendo previsível e estável. Esse sentido de identidade deixa de lado as diferenças existentes nas culturas.

HALL (1992: 13) afirma que não se pode mais falar em uma sociedade pautada no previsível ou estável; a divisão classe dominante x proletariado não mais se sustenta enquanto determinante do lugar do sujeito na sociedade. 'A identidade plenamente unificada, completa, segura e coerente é uma fantasia'. Ou seja, não há uma identidade 'mestra' que definitivamente fixe o sujeito enquanto seu portador, como definido a partir de seu local de nascimento, pertencimento racial ou outras formas de definição baseadas em características desse tipo.

Em um artigo sobre a influência da mídia na divulgação de conflitos internacionais, RAJAGOPALAN (2003: 81) afirma que desde a guerra do golfo o papel da mídia 'tornou-se inconfundivelmente visível e inegável'. O autor acrescenta que:

A mídia imprime certas interpretações pelo simples ato de designação de determinados acontecimentos, dos responsáveis por tais acontecimentos, dos atos específicos praticados pelos lados em situações de conflito etc. Posto que, de acordo com certas semânticas de grande prestígio, os nomes não passam de meras 'etiquetas' identificadoras de objetos, é preciso pensar além da semântica dos nomes próprios para encarar o fenômeno de nomeação como um ato eminentemente político. Sustentarei a tese de que é no uso político de nomes e de apelidos que consiste o primeiro passo que a mídia dá no sentido de influenciar a opinião pública a favor ou contra personalidades e acontecimentos noticiados. (ibdem, op. cit:, p. 82)

Os excertos apresentaram alguns exemplos de como a nomeação imprime um sentido específico para o sintagma e, consequentemente, para o discurso em questão. Discutimos como o uso de figuras de linguagem (a metáfora e a ironia) constitui-se como um artifício discursivo que produz efeitos a partir de uma linguagem indireta: a marginalização.

Nas palavras de CORACINI (2007: 39 et seq): enunciado, suscetível de tornar-se outro, de derivar do que seria 
aparentemente o seu sentido próprio. Toda sequência de enunciados pode ser descrita como uma série de pontos de deriva possíveis que dão lugar à interpretação. Os sentidos, segundo Pêcheux, estariam inscritos no momento histórico-social e na memória discursiva que constitui toda formação discursiva. Não a memória cognitiva, mas aquela que resulta necessariamente do esquecimento, ou melhor, da interpretação instigada pela ruptura temporal e discursiva que inscreve o sujeito e o discurso numa nova ordem.

A implicação das representações hegemônicas é que apagam as diferenças. Isso porque 'é característica do Estado a tendência à monoidentificação ou à escolha de uma identificação de referência no caso de admitir a existência de outras identidades. Assim, a ideologia nacionalista mostra-se como uma ideologia de exclusão das diferenças'.

Não queremos afirmar, entretanto, que seria possível existir uma forma de representação que abarcasse todas essas diferenças. O conteúdo é ideológico, não havendo como fugir de uma representação específica, a partir de sua inserção em uma formação discursiva.

Porém, queremos afirmar que o trabalho do LDIN com esses textos provoca um fechamento de sentidos e, assim, não abre espaço para que o aluno reconheça outros sentidos ou outras formas de pensar o sentido. $O$ aluno fica restrito a uma forma de representação das culturas que a linguagem do LDIN, a partir de condições de produção específicas, deseja criar.

O imaginário também constitui os meios em que se dão os sentidos: em nossa pesquisa, a mídia e o livro didático. Podemos afirmar que o imaginário sobre o LDIN e sobre a mídia, enquanto produtores de verdade, coincidem e mutuamente se reforçam. Segundo CORACINI (1999: 97):

O que os textos da mídia oferecem não é a realidade, mas uma construção que permite ao leitor produzir formas simbólicas de representação da sua relação com a realidade concreta.

É por ser um local onde se pressupõe encontrarmos a verdade que o LDIN se constitui como um local onde o poder se exerce. O LDIN crê na transparência da linguagem a partir da mídia, ou seja, afirma que esta traz a 
verdade, e assim, o aluno ou professor acredita na suposta veracidade dos conteúdos lá veiculados.

PÊCHEUX (1975: 181) faz uma afirmação com relação ao discurso científico que reforça esse posicionamento:

\begin{abstract}
O mito da "neutralidade científica" [...] mascara, na verdade, o fato de que a objetividade científica é indissociável de uma tomada de posição materialista, para a qual não há jamais equivalência entre as várias formulações, e que não espera jamais que a "experiência" sirva para exibir a "boa" problemática. (...) O único meio de esclarecer essa confusão é reconhecer que não há "discurso da ciência" (nem mesmo, a rigor, "discurso de uma ciência") porque todo discurso é discurso de um sujeito [...] entendendo que todo discurso funciona com relação à forma-sujeito.
\end{abstract}

Embora essa reflexão recaia sobre o discurso científico, podemos atribui-la o jornalístico, pois ambos visam a produzir discursos tomados como verdadeiros e criados independentemente de uma materialidade; teriam, assim uma existência a priori. Porém, na citação acima fica clara a verdade como materialidade. Fica mais claro quando complementada por FOUCAULT (1979a:13):

Assim,

Há um combate "pela verdade" ou, ao menos, "em torno da verdade" -entendendo -se, mais uma vez, que por verdade não quero dizer "o conjunto das coisas verdadeiras a descobrir ou se fazer aceitar", mas o "conjunto das regras segundo as quais se distingue o verdadeiro do falso e se atribui ao verdadeiro efeitos específicos de poder", entendendo-se também que não se trata de um combate "em favor" da verdade, mas em torno do estatuto da verdade e do papel econômico-político que ela desempenha. É preciso pensar os problemas políticos dos intelectuais não em termos de "ciência/ideologia", mas em termos de "vontade/poder".

Podemos dizer que as 'regras' mencionadas acima por Foucault, que fazem a distinção do verdadeiro e do falso, constituem o discurso do LDIN. Ao atribuir a verdade à mídia, a esta é dado poder. Ao trabalhar com a mídia, o LDIN se constitui num local onde se exerce o poder, por ser um local considerado didático, ou seja, onde se aprende. Foucault fala da verdade como um conjunto de procedimentos que são regulados para a produção, a lei, a 
repetição, a circulação e o funcionamento dos enunciados. Não há uma verdade, mas uma política da verdade, ou seja, uma construção de verdade.

Faz parte dessa política, não só diferentes lugares ou posições de sujeito, mas a eles é comum um espaço complementar, ou de formações nãodiscursivas. São as instituições, mas também os acontecimentos políticos, práticas e processos econômicos que os constituem. Verificamos, neste trabalho, a que formações não-discursivas os enunciados se remetem para visualizar também o que podemos caracterizar como parte da condição de seu aparecimento. Nesse sentido, chamamos de materialidade de um enunciado todas as condições necessárias para seu aparecimento, que garantam a possibilidade de sua aparição e repetição.

Por não se tratar de um tipo de força exercido pela violência ou repressão, a noção de poder atribuível ao LDIN se constitui naquela que o considera microfísico, como fazendo parte das relações cotidianas dos sujeitos, que existe em toda prática. Para FOUCAULT (1988: 89),

o poder não é algo que funcione de cima para baixo, [...] não é uma instituição e nem uma estrutura, não é uma certa potência de que alguns sejam dotados: é o nome dado a uma situação estratégica complexa numa sociedade determinada.

Ainda sobre as relações de poder, afirma que:

não se encontram em posição de exterioridade com respeito a outros tipos de relações [...], mas Ihes são imanentes; [...] as relações de poder não estão em posição de superestrutura, com um simples papel de proibição ou recondução; possuem, lá onde atuam um papel diretamente produtor. (idem, op. cit., p. 90).

Assim, podemos afirmar que o LDIN, ao articular estratégias de interpretação e de manutenção da interpretação, pode ser considerado uma materialidade que tem poder de produzir e fazer circular certos saberes, e dessa forma não estimula no aluno a reflexão. Basta observarmos alguns trechos que descrevem a proposta do livro, no que tange ao objetivo das seções de 'listening' e 'reading': 
Excerto 20:

Listening

Students develop their listening skills such as prediction, listening for specific purposes and note-taking.

Excerto 21:

Reading

They develop their reading skills and acquire essential business vocabulary. The texts provide a context for language work and discussion later in the unit. ${ }^{68}$

Excerto 22:

Reading

Squeezing a text completely dry of all useful language usually demotivates a class, but many of the longer texts in In Company Upper Intermediate are informationally rich and can usefully be revisited. ${ }^{69}$

Notamos que a ênfase é dada, nos excertos 20 e 21, à captação e reprodução: no primeiro, notemos a expressão 'listening for specific purposes and note-taking', o que remete diretamente à apreensão de idéias. Já no segundo, há a informação de que haverá contextos pré-definidos para a compreensão das formulações e para a discussão.

No excerto 22, notamos a menção a uma revisitação ao texto, ou seja, retomada dos seus sentidos (ver grifos).

Portanto, ao retomarem as noções, os posicionamentos, os pontos de vista segundo o que o discurso do LDIN apresenta, aos alunos resta uma

\footnotetext{
${ }^{68}$ Market Leader Intermediate. Teacher's Resource Book, 2007, p. 4.

${ }^{69}$ In Company Upper Intermediate. Teacher's Book, 2004, p 6.
} 
leitura acrítica, e essa atitude é tida como natural, já que o LD em geral é um discurso legitimado e fonte fiel de referência.

Os saberes articulados pelo LDIN podem ser divididos em produzidos e reproduzidos. O primeiro tipo refere-se ao fato de constituírem-se como pontos de produção e circulação de sentidos estabilizados- podemos colocar nessa categoria os textos. Já o segundo se refere à reprodução do conhecimento -o funcionamento dos exercícios.

O leitor entra naturalmente nesse jogo discursivo porque este pressupõe lugares a serem ocupados.

Podemos também afirmar que os saberes construídos pelo LDIN não se restringem aos países representados, mas também ao próprio LD, que cada vez mais é tido como fonte segura de informação.

É a partir do discurso e de seu efeito que poder e saber são produzidos, mas é a partir deles, também, que pode-se tentar obter um efeito reverso.

\begin{abstract}
Os discursos, como os silêncios, nem são submetidos de uma vez por todas ao poder, nem opostos a eles. É justamente no discurso que vêm a se articular poder e saber. [...] É preciso admitir um jogo complexo e instável em que o discurso pode ser, ao mesmo tempo, instrumento e efeito de poder, e também obstáculo, escora, ponto de resistência e ponto de partida de uma estratégia oposta. (FOUCAULT, 1988: 95 et seq)
\end{abstract}

Isso quer dizer que a resistência não está fora do poder, está no próprio poder, de forma que este mesmo se configura como local de sua possível atuação. Ao impor significados, o livro didático não proporciona ao aluno formas de subjetivação. O livro didático promove a homogeneização de significados quando, na verdade, deveria promover o trabalho com a heterogeneidade, não enquanto pluralidade, mas enquanto campo de possibilidades de identificações que não somente as impostas pelo livro, mas que proporcionassem chance ao aluno de experimentar modos de subjetivação 
que fossem mais consistentes, ou que fizessem mais sentido, tivessem maior conteúdo significativo, para ele.

Como professores, ou como alunos, estamos sujeitos aos sentidos produzidos por esses livros e somos por eles interpelados ideologicamente. Porém, faz-se necessário SEU questionamento. O aluno deveria ir além dos sentidos que o livro produz, articulando seus conhecimentos, estabelecendo ligações e construindo outros significados.

Parece-nos necessário que o aluno vivencie práticas que Ihe propiciem oportunidades de questionamento, estranhamento, ou seja, um modo de participação que não somente reproduza, mas que the permita 0 questionamento das diferenças entre ele e o outro, o estranho, o estrangeiro. 


\section{CONSIDERAÇÕES FINAIS}

O objetivo desta dissertação foi apresentar e discutir o modo de funcionamento dos livros didáticos britânicos de inglês para negócios enquanto veículos ideológicos que constituem sujeitos e seus discursos. Buscamos confirmar nossa hipótese de que embora o livro didático se apresente como heterogêneo, de fato, ocorre uma homogeneização das culturas representadas por meio de regimes de verdade, ou seja, regras a partir das quais verdades são constituídas e constituem outras verdades.

Como abordagem teórica, apoiamo-nos na análise discursiva proposta por Michel Pêcheux, que considera a língua como materialidade inscrita na história, na ordem dos acontecimentos, distanciando-se da noção da mesma enquanto ferramenta para comunicação. Já o sujeito é considerado como o indivíduo interpelado pela ideologia que apenas assume uma posição no discurso - não é considerado como origem deste.

Tratamos também dos conceitos de verdade, poder e saber, segundo o que postula Michel Foucault $(1969,1971,1979)$. Para o autor, a verdade existe enquanto construção e é sustentada pela exterioridade, ou seja, são as instituições, inseridas em dado contexto sócio-histórico-ideológico, que produzem não só regras do que é certo e aceitável, mas também definem as esferas de circulação desses discursos na sociedade. Exemplos seriam os discursos jornalístico e científico, aceitos na sala de aula como discursos de verdade, ou seja, discursos legitimados para a produção de verdades.

Os livros analisados representam as culturas a partir de uma linguagem denominada 'autêntica', que afirma trazer o real dos fatos, o que produz um sentido aparentemente único da origem do discurso do LDIN. Porém, uma análise discursiva dos sentidos para esse termo mostra que não é possível considerar uma linearidade ou unicidade do conceito. Há diversas vozes, até mesmo contraditórias, que constituem o discurso chamado 'autêntico', mas que 
não são percebidas por estarem categorizadas como pertencentes a esse tipo de discurso sendo, assim, naturalizadas.

A análise das vozes produzidas pelo discurso denominado autêntico demonstra que a heterogeneidade de vozes implica, de fato, uma homogeneidade discursiva, pois tais vozes possuem um funcionamento que busca afirmar um ponto de vista específico, que não oferece espaço a outros, interpelando o leitor na produção do sentido que se quer produzir. Sendo restrito à esfera de autêntico já definida, o discurso do LDIN é produzido por vozes múltiplas, que são legitimadas pela mídia britânica e que visam a fazer prevalecer essa perspectiva. Os dizeres do LDIN são vistos como transparentes e livres de relações de poder, porém a análise demonstrou que as formulações, uma vez provenientes do discurso denominado autêntico são neutralizadas a partir da legitimação de uma única voz - a britânica assumida pelo autor do LD.

Os sentidos produzidos pelas vozes analisadas são também homogeneizantes, pois o modo de construção das formulações colabora para a instauração de sentidos desejados pelo discurso britânico. O uso de certos recursos argumentativos como asserções categóricas, certos tipos de advérbios, imperativos, figuras de linguagem, fixam, de modo diferente, mas com mesmo efeito - congelamento de sentidos -, tipos de saberes sobre as culturas. Estas são faladas de modo a produzir sentidos que apagam 0 processo histórico subjacente aos enunciados, ora exaltando, ora marginalizando as várias culturas mencionadas.

As representações, produzidas pelos textos e reproduzidas pelos exercícios, atribuem características fixas às culturas, imprimindo-Ihes uma identidade una, totalizante. Porém, como vimos, essa atribuição não se sustenta, dada a heterogeneidade constitutiva dos sujeitos e sentidos. As nações, enquanto totalidades, são construções, trabalho do imaginário.

Verificamos que os discursos jornalístico e científico, considerados discursos da 'verdade', ao fazerem parte do LDIN, que também possui esse 
caráter, reforçam o discurso deste. Por isso consideramos que o discurso do LDIN é tomado na transparência, como algo já pronto para consumo.

Os alunos, uma vez que são sujeitos constituídos por esses e outros discursos, constroem significados, mas estes a partir das representações a que tem acesso são totalizantes e fecham sentidos, isto é, os alunos são apenas instados a aceitarem o sentido estabelecido pelo livro, de forma transparente.

O livro didático acaba sendo o discurso da verdade, tanto quanto 0 jornalístico e o científico, e não um local a partir de onde poderia haver questionamentos, mobilizações de conhecimentos e discussões.

Não objetivamos, com a pesquisa, questionar a importância do LD enquanto principal meio utilizado para o aprendizado na nossa sociedade. Porém, o que gostaríamos, com a análise empreendida, é mostrar o quanto nossa cultura está, ainda, arraigada em um processo de ensino baseado na repetição ou reprodução de sentidos e formas de se pensar positivistas, onde o importante é 'o que o texto significa', em detrimento de 'como esse texto significa', que deveria ser a preocupação e a base para todo processo de ensino.

Acreditamos que o papel do livro didático ficará limitado enquanto este constituir-se como um meio de acesso à informação e não puder provocar estratégias de estranhamento à informação fornecida; seu diferencial deveria ser aquele comprometido em tornar-se um local de possibilidades para o aluno (e outros sujeitos que o utilizam), um local de interpretação e resistência. Um meio, a nosso ver, importante para produzir e mobilizar novos conhecimentos. 


\section{REFERÊNCIAS BIBLIOGRÁFICAS}

ARAÚJO, C.E.B. Ensino Reflexivo e Discurso Neoliberal: Análise de uma Experiência. 2002. 127 f. Dissertação (Mestrado em Estudos Linguísticos do Inglês) -Faculdade de Filosofia, Letras e Ciências Humanas. Universidade de São Paulo. São Paulo. 2002.

AUTHIER-REVUZ, J. Palavras Incertas: As Não-Coincidências do Dizer. Campinas, SP: Editora da UNICAMP, 1998.

\section{Entre a Transparência e a Opacidade: Um Estudo}

Enunciativo do Sentido. Porto Alegre, RS: EDIPUCRS, 2004.

BAKHTIN, M. Marxism and the Philosophy of Language. New York and London: Seminar Press, 1973.

BERWALD, J. P. (1986) Au courant: Teaching French Vocabulary and Culture Using the Mass Media. Language in Education: Theory and Practice 65, Centre for Applied Lingusitics, Washington D. C.

BLOOR, M. The English Language and ESP Teaching in the 21st Century. In: ESP In Latin America. F.MEYER, A.BOLIVAR, J.FEBRES, M.B.SERRA (eds.) Universidad de Los Andes. CODEPRE, 1997.

BRAIT, B. (org.) (2005) Bakhtin. Dialogismo e Construção do Sentido. Campinas, SP: Editora da UNICAMP, ed. 2008.

BRANDÃO, H. N. Subjetividade, Argumentação, Polifonia. A propaganda da Petrobrás. São Paulo: Fundação Editora da UNESP: Imprensa Oficial do Estado, 1998.

CARMAGNANI, A.M.G. A Concepção de Professor e de Aluno no Livro Didático e o Ensino de Redação em LM e LE. In: CORACINI, M.J.F. (Org.) Interpretação, Autoria e Legitimação do Livro Didático: Língua Materna e Língua Estrangeira. Campinas, SP: Pontes, 1999, pp. 127- 133.

CARMAGNANI, A. M. Processos de Identificação, mídia e discurso didáticopedagógico. In Crop. Questões de Linguagem e Identidade. Revista da Área de Língua Inglesa e Literatura Inglesa e Norte-Americana do Departamento de Letras Modernas/ Faculdade de Filosofia, Letras e Ciências Humanas. Universidade de São Paulo.-n 1 (1994) São Paulo: Humanitas/ FFLCH/USP, 2003, pp. 105-122.

CARVALHO, A.A.C.C.A.S. Materiais Autênticos no Ensino das Línguas Estrangeiras. In: Revista Portuguesa de Educação. Universidade do Minho. 1993, 6 (2), 117-124. Disponível em 
http://repositorium.sdum.uminho.pt/bitstream/1822/518/1/1993,6(2),117124(AnaAmeliaAmorimCarvalho).pdf ) Acesso em: 19 jul. 2012.

CELANI, M.A.A. A. 1998 Retrospective View of an ESP Teacher Education Programme. the ESPecialist, 19. 2: 233-244.

CHEW, Phyllis Ghim-Lian. Linguistic Imperialism, globalism and English Language. In: Graddol, David e Meinhof Ulrike H., English in a Changing World. Biddles Ltd, Guildford. United Kingdom, 1999.

CORACINI, M.J.F. O Processo de Legitimação do Livro Didático na Escola de Ensino Fundamental e Médio: Uma Questão de Ética. In CORACINI, M.J.F. (org.) Interpretação, Autoria e Legitimação do Livro Didático. Língua Materna e Língua Estrangeira. Campinas, SP: Pontes, 1999, pp. 33-43.

Um Fazer Persuasivo. O Discurso Subjetivo da Ciência. Campinas, SP: Pontes Editora, 1991.

As Representações do Saber Científico na Constituição da Identidade do Sujeito-Professor e do Discurso da Sala de Aula. In: CORACINI, M.J.R.F. (org.) Identidade e Discurso. Desconstruindo Subjetividades. Campinas: Ed. da UNICAMP; Argos Editora Universitária, 2003. pp 319-336.

CORACINI, M.J.R.F. \& PERUCHI, I. O discurso da Cultura e a Questão da Identidade em Livros Didáticos de Francês como Língua Estrangeira. In: CORACINI, M.J.R.F. (org.) Identidade e Discurso. Desconstruindo Subjetividades. Campinas: Ed. da UNICAMP; Argos Editora Universitária, 2003. pp 363-385.

A Escamoteação Da Heterogeneidade Nos Discursos da Linguística Aplicada E Da Sala de Aula. Letras- Revista do Mestrado em Letras da UFSM, (RS), n. 14, janeiro-junho, 1997. P. 39-63.

A Celebração do Outro. Arquivo, Memória, Identidade. 2007 (org.) (1995) O Jogo Discursivo na Aula de Leitura. Língua Materna e Língua Estrangeira. Campinas, SP: Pontes Editores, 2010.

DELEUZE, G. (1988) Foucault .São Paulo: Brasiliense (ed. 2008).

DUDLEY-EVANS, D. \& ST JOHN, M. (1998) Developments in English for Specific Purposes. Cambridge University Press, 2006.

FOUCAULT, M. (1969) A Arqueologia do Saber. Rio de Janeiro: Forense Universitária, 2010.

(1971) A Ordem do Discurso. São Paulo: Ed. Loyola, 2003.

Estratégia, Poder-Saber (org. Manoel Barros da Motta) tradução Vera Lucia Avellar Ribeiro. 2 ${ }^{\underline{a}}$ Ed. Rio de Janeiro: Forense Universitária, 2010. 
(1979a). Microfísica do Poder. Rio de Janeiro: Edições Graal

(2008).

NAU Editora, 2005.

A Verdade e As Formas Jurídicas. $3^{\mathrm{a}}$ edição. Rio de Janeiro:

(1988) História da Sexualidade 1. A Vontade de Saber. Rio de Janeiro: Edições Graal, 1999.

(1979b) What's an Author? In J. Harari (Ed.) Textual Strategies -Perspectives in Post Structuralist Criticism. Ithaca: Cornell University Press: 141-159.

GENTILI, P.A. O Discurso da "Qualidade" como Nova Retórica Conservadora no Campo Educacional. In: GENTILI, P.A.; SILVA, T.T. Neoliberalismo, Qualidade Total e Educação. Petrópolis: Vozes, 2001. pp 113- 177.

GREGOLIN M. R. (org). Discurso e Mídia. A Cultura do Espetáculo. Coleção Olhares Oblíquos. Claraluz Editora: 2003.

GREGOLIN, M. R. Foucault e Pêcheux na Análise do Discurso: Diálogos \& Duelos. $2^{\underline{a}}$ edição. São Carlos: Editora Claraluz, 2006.

GRIGOLETTO, M. Memória, Funcionamento discursivo e lugar de escuta em editoriais jornalísticos. In Crop. Questões de Linguagem e Identidade. Revista da Área de Língua Inglesa e Literatura Inglesa e Norte-Americana do Departamento de Letras Modernas/ Faculdade de Filosofia, Letras e Ciências Humanas. Universidade de São Paulo.-n 1 (1994) -.-São Paulo: Humanitas/ FFLCH/USP, 2003 (p. 139-154)

GRIGOLETTO. M. Processos de Significação na Aula de Leitura em Língua Estrangeira. In: Coracini: M.J.F. (Org.) O Jogo Discursivo na Aula de Leitura: Língua Materna e Língua Estrangeira. Campinas, SP: Pontes, 1995 (edição 2010), pp. 103-111.

. Leitura e Funcionamento Discursivo do Livro Didático. In: CORACINI, M.J.F. (Org.) Interpretação, Autoria e Legitimação do Livro Didático: Língua Materna e Língua Estrangeira. Campinas, SP: Pontes, 1999, pp. 67-77.

A Resistência das Palavras. Discurso e Colonização Britânica na Índia. Campinas, SP: Editora da Unicamp, 2002.

GUIMARÃES, E. Semântica do Acontecimento: um Estudo Designativo da Enunciação. Campinas, SP: Pontes, 2ª edição, 2005.

GUIMARÃES, E. Texto e Argumentação: Um Estudo de Conjunções do Português. Campinas, SP: Pontes, 1987. 
HALL, S. (1992) Identidade Cultural na Pós Modernidade. Tradução Tomaz Tadeu da Silva e Guaracira Lopes Louro, Rio de Janeiro: DP\&A, 2006.

HALL, S. Representation: Cultural Representations and Signifying Practices. New York: Sage Publications, 1997.

HOWATT, A.P.R. (1984) A History of English Language Teaching. Oxford: Oxford University Press, edição 1988

HUTCHINSON, Tom \& WATERS, Alan. (1987) English for Specific Purposes: A learner-centered approach. Cambridge: Cambridge University Press, 2005.

KIENBAUM, B, RUSSEL, A. J. e WELTY, S. (1986). Communicative Competence in Foreign Language Learning with Authentic Materials. Final Project Report. ERIC reproduction document, ED 275200.

KRESS, Gunther and THEO van Leeuwen (1996). Reading Images: The Grammar of Visual Design. London: Routledge, 1999.

KRESS, Gunther and THEO van Leeuwen. Representation and Interaction: Designing the Position of the Viewer. In JAWORSKI, A. \& COUPLAND, N. (eds.) The Discourse Reader. London: Routledge: 1999.

ORLANDI, E. P. (2007) As Formas do Silêncio: No Movimento dos Sentidos. Campinas, SP: Pontes (ed. 2010)

(1999) Análise de Discurso. Princípios e Procedimentos. Campinas, SP: Pontes (ed. 2010).

PÊCHEUX, M. (1975) Semântica e Discurso. Uma Crítica à Afirmação do Óbvio. São Paulo: Editora da UNICAMP, 2009.

(1988) O Discurso: Estrutura ou Acontecimento. Tradução: Eni P. Orlandi. Campinas, SP: Pontes Editores, 2006.

RAJAGOPALAN, K. Por uma Linguística Crítica. Linguagem Identidade e a Questão Ética. São Paulo: Parábola Editorial, 2003.

RAMOS, R.C.G. Instrumental no Brasil: A Desconstrução de Mitos e a Construção do Futuro. In: FREIRE, M.M.; ABRAHÃO, M.H.V.; BARCELOS, A.M.F. (Orgs.) Linguística Aplicada e Contemporaneidade. -São Paulo, SP: ALAB; Campinas, SP: Pontes Editores, 2005.

RICHARDS, Jack C. \& RODGERS, T. S. (1986) Approaches and methods in language teaching: $A$ description and analysis. Cambridge: Cambridge University Press, 1994.

ROGERS, C. e MEDLEY, F. (1988). Language with a Purpose: Using Authentic Materials in the Foreign Language Classroom. Foreign Language Annals, 21, 5, 467-478. 
SILVA, T.T. A Nova Direita e as Transformações na Pedagogia da Política e na Política da Pedagogia. In: GENTILI, P.A.; SILVA, T.T. Neoliberalismo, Qualidade Total e Educação. Petrópolis: Vozes, 2001, pp 9-29.

SOUZA, D. M. Autoridade, Autoria e Livro Didático. In: CORACINI, M.J.F. (Org.) Interpretação, Autoria e Legitimação do Livro Didático. Língua Materna e Língua Estrangeira. Campinas, SP: Pontes, 1999, pp. 27-31.

Do Monumento ao Documento. In: Coracini M.J.F. (Org.) $O$ Jogo Discursivo na Aula de Leitura: Língua Materna e Língua Estrangeira. Campinas, SP: Pontes, 1995 (edição 2010), pp. 113-118.

Livro Didático: Arma Pedagógica? In: CORACINI, M.J.F. (Org.) Interpretação, Autoria e Legitimação do Livro Didático. Língua Materna e Língua Estrangeira. Campinas, SP: Pontes, 1999, pp. 93-103.

SWALES, J. Episodes in ESP. Oxford: Pergamon Press, 1985.

WIDDOWSON. H.G. (1978) O Ensino de Línguas para a Comunicação. Campinas, SP: Pontes, 2ª edição, 2005.

WIDDOWSON. H.G. (1973) An Applied Linguistic Approach To Discourse Analysis. Ph. D. Thesis. Department of University of Edinburgh.

WILKINS, D. (1976). Classroom Techniques. In E. R. Baer (ed.). Teaching Languages. London: BBC.

\section{LIVROS DIDÁTICOS}

MASCULL, Bill. Market Leader Intermediate Teacher's Resource Book. England: Pearson Education Limited, 2002.

KENT, Simon; FALVEY, David; COTTON, David. Market Leader Intermediate Business English Course Book. $3^{\text {a }}$ edição. England. Pearson Education Limited: 2006.

KENT, Simon; FALVEY, David; COTTON, David. Market Leader Upper Intermediate Business English Course Book. England: Pearson Education Limited, 2006.

MASCULL, Bill; HEITLER, David. Market Leader Upper Intermediate Business English Teacher's Book. England: Pearson Education Limited, 2006. 
ALLISON, John, et al. In Company Elementary. Teacher's book. Londres: MacMillan Publishers, 2005: 6.

GOMM, Helena, et all. In Company Intermediate Teacher's Book. Oxford: Macmillan Publishers Limited, 2002.

SHARMA, Pete et all. In Company Upper Intermediate Teacher's Book. Oxford: Macmillan Publishers Limited, 2008.

IBBOTSON, Mark; STEPHENS, Brian. Business Start Up 1 Teacher's Book. Cambridge: Cambridge University Press, 2010.

IBBOTSON, Mark; STEPHENS, Brian. Business Start Up 2 Teacher's Book. Cambridge: Cambridge University Press, 2011.

COMFORT, J. Effective Presentations. Oxford: Oxford University Press, 1996.

COMFORT, J. Effective Telephoning. Oxford: Oxford University Press, 1998.

HOLLETT, Vicki. Business Opportunities. Oxford: Oxford University Press: 1996.

HOLLETT, Vicki. Business Objectives. Oxford: Oxford University Press: 1996. 


\section{ENDEREÇOS ELETRÔNICOS}

$<$ http://www.pearsonlongman.com/intelligent business/course overview.html> http://www.cambridge.org.br/cambridge-brazil/about-us

http://www.pearsonelt.com/

http://www.oup.com.br/oxford-brasil

http://www.pearsonlongman.com/intelligent business/video.html

http://www.macmillanenglish.com/Authors.aspx\#

http://www.macmillan.com.br/conheca-os-autores/detalhe.php?|D=ODE=

http://www.macmillanenglish.com/Author.aspx?id=29620

http://www.market-leader.net/meet-the-authors.html 


\title{
Artigo B- Now, about this web thing
}

\author{
Reading \\ Read this article by David Bowen from the Financial Times and \\ do the exercises that follow.
}

\section{Now, about this web thing}

David Bowen

Your corporate website is an investment that is quite likely the biggest element in your communications budget; whose Return on 5 Investment (ROI) you cannot measure; and whose benefits are difficult to describe. And now I would like to explain why you should be spending more on it.

10 It is easy to say why companies have websites. It is because they grew up for fun (it is fun building a website; you should try). But what purpose does the site serve 15 and why have you just authorised another large cheque to keep it going and growing? Well, if you didn't sign that cheque and the site disappeared, what would hap20 pen? In the short term, unless your company actually sells things online, your revenue would not suffer, and your costs would fall; but here are the other effects I 25 predict.

First, your company would see the flow of phone, fax or email enquiries from customers reduce sharply. They use your site, via ${ }_{30}$ Google, to find out your details - the most valuable role of any website is as a simple contact point. Second, you would start getting worrying feedback from Human 35 Resources that the staff were wondering what was going on. About one in ten visitors to your site are likely to be employees. They want to know what is happening in the 40 company, too.

Third, your investor relations team would get irate phone calls from analysts looking for an elusive figure from the 1999 annual 45 report. Analysts are used to finding historical data on company sites, and you don't want to upset them, do you?

Fourth, journalists would be 50 phoning your press office to confirm such details as how the president of your Polish operation spelt his name, or whether you still owned that company in Indonesia. 55 You may also get calls from careers officers in colleges, wondering if your company still existed and demanding extra copies of brochures for students. In due 6o course, you would find the quality of recruits was falling, because people had come to rely on the web to get a feeling for a potential employer.

65 Disastrous though this may be, it does not explain why you should actually be increasing investment in your website. I said earlier that most websites grew up by mistake. As a result, most large organisations now have web presences that are grossly inefficient, racking up unnecessary 'hosting' costs on dozens or even hundreds 75 of servers. Many large organisations are now looking at these costs, and thinking how much more sensible it would be to bring the sites together. Extra benefits 8o would then tumble forth: further cost savings from sharing words pictures and interactive tools, and greatly increased quality for the same reason.

85 But of course this is going to cost money in the short term. So when your corporate affairs director asks you to approve a project with no apparent ROI, please don't laugh in his face. Ask your fellow CEOs instead; I bet they are getting very similar requests.

From the Financial Times

\section{Artigo C- A financial history of the world}

Oct 9th 2008

From The Economist print edition 


\section{One way to make sense of the present financial chaos is to look back at the past}

THE typical career of a Wall Street banker lasts about a quarter of a century, enough to span just one big financial crisis. As Niall Ferguson explains in his new book, "The Ascent of Money", which will be published next month, today's senior financiers would have started out in 1983, fully ten years after oil and gold prices first began the surge that had ruined the previous generation of money men. That, he concludes, is a "powerful justification for the study of financial history." Mr Ferguson is right. The world needs a book that puts today's crisis into context. It is too late now to warn investors about expensive houses and financiers about cheap credit. But perhaps the past can help make sense of the wreckage of banks, brokers and hedge funds that litters the markets. Looking back may help suggest what to do next. And when the crisis is over and it is time for the great reckoning, the lessons of history should inform the arguments about what must change.

This rushed, uneven book, by a British-born Harvard University professor who made his name a decade ago with a history of the Rothschild banking dynasty, will contribute less than expected to that debate. It has strengths, including a tidy account of the run-up in housing markets and of the symbiotic rivalry between America and China. But in the earlier chapters-the history, oddly enough, where you would expect Mr Ferguson's ambitions for his subject to quicken his judgments-the words rarely come to life, either as a source of ideas or as narrative.

Perhaps the book was bound to be flawed, given the pace with which today's crisis has torn through the markets. As the debacle has unfolded, from a housing crisis, to a credit bust, a bank run and what now looks ominously like a global recession, each episode has posed different questions. Finishing his manuscript in May this year, Mr Ferguson must have been dizzy with the unravelling of certainties. And yet, he is at his strongest in his reading of the news. His story of what is happening today shows prescience, even if it is necessarily incomplete.

It may be that Mr Ferguson was too distracted by the present to pay enough attention to the past. Claiming to be "A Financial History of the World", the book 
dutifully dabbles in societies, such as the Inca, who did not see gold and silver as money, and in the pre-Christian Mesopotamian clay tablets that served as credit notes for commodities. He traces the transformation of banchieri, named for the benches where money was changed, into the families that dominated the political and cultural life of Renaissance Italy and from there into modern bankers. He explains how the bond market had its origins in the state's need for money to finance war. He describes how manias have repeatedly engulfed greedy investors over the centuries-concentrating on John Law, whose schemes ruined 18th-century France. And he rehearses the story of financial risk from its origins in Enlightenment Scotland.

Yet the reader is left wondering quite who the book is aimed at. The finance specialist will not find enough here to begin to compete with the work of Charles Kindleberger, an economic historian. And the reader who wants to know how finance is interwoven with general history would do better to turn to Jeffry Frieden's excellent 2006 work, "Global Capitalism".

Mr Ferguson may seem to be speaking to a general audience, given that he has taken his title from "The Ascent of Man", Jacob Bronowksi's book and television series of a quarter-century ago which analysed the contribution of science to civilisation. Yet these readers will be baffled by passages that breezily toss around ideas like "sterilisation"-the issue of bonds by a government to mop up the inflation-inducing money it prints to buy foreign currency. And they may be put off by Mr Ferguson's attempt to be jolly. After two and half pages on the mathematics of bond yields, for example, comes this quip: "So how did this 'Mr Bond' become so much more powerful than the Mr Bond created by lan Fleming? Why, indeed, do both kinds of bond have a licence to kill?"

Of far greater interest is Mr Ferguson's general theory, which does not emerge until the end of the book. He thinks that finance evolves through natural selection.

Although the professor cautions against the sort of Darwinism that sees evolution as progress, he believes that new sorts of finance are constantly coming into being as the environment changes. The sequence of creation, selection and destruction is what has generated many of the financial techniques that modern economies depend on. 
This leads Mr Ferguson to make two timely points. One is to remember that evolution depends on extinction as well as creation. You have to allow illadapted techniques to fail if you are going to get something new. As the world rushes around rescuing every bank in sight, it is a reminder that the guarantorstate will later have to administer painful medicine.

The other is to observe the wonder of what financial evolution has created. Just now it is only natural to think of the "roller-coaster ride of ups and downs, bubbles and busts, manias and panics, shocks and crashes." But Mr Ferguson sees something else too: "From ancient Mesopotamia to present-day China...the ascent of money has been one of the driving forces behind human progress: a complex process of innovation, intermediation and integration that has been as vital as the advance of science or the spread of law in mankind's escape from the drudgery of subsistence agriculture and the misery of the Malthusian trap." Amid this financial bust, cleave to that.

Disponível em

<http://www.pearsonlongman.com/intelligent_business/images/teachers_resour se/Pdf1.pdf>. Acesso em: 19 jul. 2012.

Artigo D- On lying

THE WORD "lie" means something very specific. It doesn't mean a misleading statement, or an exaggeration, or a half-truth: it is a falsehood advanced intentionally and knowingly. That is why, in my column last week, I wrote that probably only Tony Blair and his crew could know whether they "lied" about Iraq's weapons of mass destruction. Only they can know what was in their heads, and how far their public utterances diverged from their inner convictions. For that reason the question of lying over Iraq seems to me a bit of a red herring and distraction. What can be proved about their sloppiness and embellishments, and has been, is bad enough. 
Lying is back in the news this week. Gordon Brown stands accused by various newspapers and columnists of deliberately misleading the public about the government's fiscal position.

Ditto Ed Balls, the prime minister's henchman, who evidently doesn't take kindly to having his integrity impugned in this way. David Cameron is a bit more periphrastic, knowing that in political parlance the "l" word is a nuclear accusation; but he came pretty close to it yesterday with his talk of "a thread of dishonesty" running through Mr Brown's premiership.

There are (at least) two big questions provoked by this revived interest in lying. First and most obviously, are Mr Brown, Mr Balls and others really and indisputably liars? Do the fiscal figures they cite and twist in any way support the interpretation they put on them-at least enough to make it credible that they believe what they are saying, even if no-one else does?

If so, they may not be lying. They may be over-optimistic, incompetent or deluded. But they are not obviously liars.

Second, if he thinks it, should Mr Cameron say it? Why beat around the bush?

On the first: I agree that the government's selective use of figures, fondness for comparing like with unlike, switching between cash and real-terms numbers for spending, etc, are dodgy and dishonourable. That is bad enough. But are the ministers lying? It seems to me that one potential reason to think they are not is their own self-perception. Just as medieval peasants in France could not imagine a universe without god-such an idea was not within their range of thinkable thoughts-it is possible that Mr Brown and others simply cannot countenance the scale of the hole they have helped to dig, and in particular find it hard to accept that, in the unlikely event they win the election, they will have to impose the sort of public-spending cuts they have spent their entire political careers berating. ( $\mathrm{am}$ trying to be charitable.) Alternatively, there may be a plan for big tax rises, as yet unannounced, that will help to substantiate their claims on spending. That would be a form of deception too, but a different one. On the second question: On the one hand, if Mr Cameron thinks it, he should say it. But on the other, he has to take Mr Brown on (at PMQs, on the television, in adverts) for almost another year. If he levels one of the gravest charges possible at him now, where does he go afterwards? The risk is that he will look like an actor who comes on ranting in the first act and then has no higher range 
to work through in the subsequent ones. There is also the danger that he comes across as bullying and downright rude.

What do you think?

Disponível em

http://www.pearsonlongman.com/intelligent business/images/teachers resours e/Pdf9.pdf> Acesso em: 19 jul. 2012.

Artigo E: Different goals

There was a recent news report about an anthropologist who discovered a lost tribe in the Amazon whose way of life had hardly changed since the Stone Age and who had never seen a car or met a foreigner. What shocked her most about the natives, however, was not their strange social customs or mysterious religious rituals, but the fact that several of them were wearing Manchester United football shirts!

Whether or not that report is true, what is certain is that Manchester United stopped being just a famous football team several years ago and became a highly successful multinational corporation. The words 'football' and 'club' were actually dropped from the players' badges in 2000 in an effort to strengthen corporate image. Will a successful stock market flotation in 1991 and a market value, according to City accountants Deloitte \& Touche, of over £110 $\mathrm{m}$. Manchester United is as much a triumph of de media as of great soccer.

Since 1990 the club has won - to date -four League titles, a League Cup, three FA Cups, A European Cup Winners Cup and a European Super Cup. But is was the media coverage of the 1990 World Cup and the arrival of Sky TV in 1993 that really transformed the game into the money-making industry it is today. 'Top clubs have grown on the back of television contracts' says Richard Baldwin of Deloitte \& Touche'. Teams like Bayern Munich, Arsenal, Real Madrid and Galatasaray turn profits many bluechip companies they would envy.

'It's an oil well', says Manchester United's former head of merchandising'. He should know. The team's megastore at Old Trafford, which stocks 1,500 
different items, is constantly packed, and merchandising outlets as far as Singapore, Hong Kong and Sidney attract thousands of fans who couldn't even tell you where Manchester in on the map.

'United look and behave very much like a traditional business from a corporate point of view', says Nigel Hawkins, a financial analyst at Williams de $\mathrm{Bröe}^{70}$ They have a strong brand and they have worked to maximize it by bringing in good people.' They certainly have. One sponsorship deal alone -with Vodaphone -netted Manchester £30 million.

But not everyone is so enthusiastic about the branding of soccer. Many of the small clubs, for example, whose matches never get air time, struggle to survive. Since that's where tomorrow's stars will come from, that could be very bad for the game's future. And some people are also concerned about the number of foreign players bought by the top clubs to make sure they keep winning trophies. No wonder the England team does so badly, they say, when most of the best players in the English Premier League have foreign passports!

Recently, even some of the stars themselves have complained about contracts that permit them to be traded for millions like thoroughbred racehorses. Image, said one player, you worked for IBM and not only did they insist you appear in all their TV commercials, but when you wanted to move to Hewlett-Packard, they demanded ten million dollars from your new employer! He may have a point. But systems analysts don't make headlines and not even IBM has its logo in the Amazon rainforest.

\footnotetext{
${ }^{70}$ In Company Intermediate. Teacher's Book. 2002. p. 87.
} 


\section{Artigo F: Virtual teams}

\section{Virtual teams: Global harmony is their dream}

Sarah Murray

If managing diversity in the workplace is a tough task for business leaders, the challenges of keeping executives from different back5 grounds working together efficiently in various parts of the world is even more difficult. "One of the things you should take into account is whether your team 10 includes members who don't speak English well," says Joanne Yates, a professor of management at MIT Sloan, who has studied the use of communication and infor15 mation systems in companies. "Any good virtual team has a communication plan that includes weekly conference calls or e-mail check-ins, but with a virtual team 2o where not everyone speaks English well, the regular reportins should be in written mode rather than by phone or conference call."

25 The other advantage of e-mail communications is that, for those working in different time zones, group messages can be responded to when it is convenient, reducing zo the need for early morning or late night calls. At the same time, using e-mail can remove much of the hierarchy of professional communications, since many execu35 tives find it far less intimidating to send an e-mail to someone in a senior position than to telephone them.

However, cultural or behaviour40 al differences that can manifest themselves in face-to-face working situations can be exacerbated in virtual team working, particularly when the group has members 5 from different backgrounds. One reason for this is that, when one is physically immersed in a new culture, it takes less time to adapt to the social norms and become 5o aware of cultural sensitivities. So those trying to do this at a distance may find it tougher to fit in, increasing the potential for misunderstandings between team 5 members. "You don't build the relationships in the same way as you do working face-to-face," says Martin Galpin, managing psychologist at Pearn Kandola, a UK

60 based research business and consultancy of occupational psychologists.
Prof Yates points out that, when people in professional groups 65 come from different backgrounds or cultures, it is often useful to appoint someone in the team who knows both cultures as the person responsible for setting the norms 70 of working behaviour during a project that is being carried out from different locations.

And virtual working certainly does not eradicate the sort of cul75 tural misunderstandings that can arise in a face-to-face situation. Prof Yates cites an online miniconference she recently observed that took place between a group of 80 US and Japanese executives working in the research and development unit of a Japanese company. "A Japanese executive was putting text into a window for instant 85 messaging when one of the Americans started asking questions in the middle of the presentation," she explains. "That was not culturally familiar and go required an instant response, which caused real problems."

From the Financial Time 


\section{Artigo I- South Korea}

\section{Conversation}

You may be asked personal questions about your age, salary, education, religion, and family life. If you don't want to answer, remain polite but try to politely avoid answering. In most cases, people ask in order to establish a rapport by finding common ground.

\section{Gift-giving}

Giving gifts is a common practice in the workplace, and the receiver is expected to give a gift in return. Good gifts for a first trip include office items with your company logo or something produced in your country. Your gift should be of good quality but modestly priced. When you plan to give a gift to several people within an organisation, be sure to give a gift of greater value to the senior person.

\section{Entertainment}

Drinking is an important part of doing business. It is common to be invited out in the evening to a restaurant/bar where there will be a lot of alcohol. Towards the end of an evening the most honoured person will be asked to sing solo. Make sure that you know one very simple song and do your best. Refusing to sing is considered-bad manners.

Adapted from www.executive.com

\section{Artigo J- Brazil}




\section{Conversation}

Conversations tend to be fast and lively. You may sometimes be asked personal questions about your income, religion, and marital status. If you don't want to reveal this information, remain polite but give a vague reply.

\section{Gift-giving}

Giving a gift is not necessary during a first meeting. Instead, offer to buy lunch or dinner and use this opportunity to learn more about your guest's tastes. This way, later on when gifts are exchanged, you'll be able to give an appropriate gift. Do not give anything that is obviously expensive. Your generosity may cause embarrassment or be misinterpreted. Small electronic items are often appreciated. Good choices include scientific calculators, electronic address books and pocket $C D$ players, etc.

\section{Entertainment}

Business entertaining is conducted over lunch or dinner. You are expected to arrive on time. It is business etiquette in Brazil to shake hands with everyone in your company, both upon arrival and upon departure. It's unusual to touch food with your fingers. Cut all foods, including fruit and sandwiches, with your knife.

Adapted from www.executive.com

\section{Artigo K- Nobody does it better}

\section{NOBODY does it better}

THE JAMES BOND movies are the longest-running, highest grossing film series in history. Current turnover stands at over $\$ 6$ billion. In fact, the combined earnings of the Star Wars and Star Trek series and the most successful single film ever, Gone with the Wind, still fall $\$ 750$ million short of Bond at the box office

10 Bond is also the most profitable film series ever. The special effects may cost much more these days, but the films still enjoy $30 \%$ profit margins, not including merchandising. Even Stephen Spielberg's

15 blockbusters ET, Jurassic Park and the Indiana Jones trilogy can't compete.

Bond appeals to men and women, adults and children alike. From Russia with Love was one of President

20 Kennedy's top ten favourite books. But James Bond is no longer just a Hollywood hero; he's a bestselling brand. Although the actor playing Bond has changed several times over the last 25 forty years, and although there are no more Ian Fleming novels on which to base the films, the series goes on and on.

The film business is risky -

30 seven out of ten movies lose money. But brand awareness of Bond is so strong that even people who don't like the films instantly recognise the Bond music, fast cars

35 and glamorous women. They

know that James takes his vodka Martini 'shaken not stirred'.

And then there is

Bond himself - certainly

40 the key factor in 007's

commercial success. With so much money at stake, the choice of a new Bond always makes front-page news. Not

45 everyone agreed in 1962 with the decision to choose a virtually unknown Sean Connery as the first James Bond, and Connery was only paid $£ 7,000$ for $\mathrm{Dr} \mathrm{No}$, but it

50 was perhaps one of the best recruitment decisions ever made. And the rest, as they say, is history.

\section{Artigo L- Loyalty cards}

\section{Jan 27th $2011 \mid$ TOKYO | from PRINT EDITION}


YASUNAGA KOJIMA'S grocery shop, near Tokyo's Tsukiji fish market, has been in business since his grandfather started it almost 100 years ago. He lives above it with his wife. Outside he sells $¥ 99$ (\$1.20) bunches of bananas and other fruit, undercutting even the discount convenience store across the street, which sells everything at $¥ 105$.

His customers, many of them pensioners, cherish such bargains. They come in, on average, twice every three days, and buy just enough to put together a few meals. Some economists consider such stores an anachronism, and blame small retailers for the meagre productivity of Japan's service sector. But Mr Kojima's store is no culprit. It is part of a 1,800-strong community of local cooperative stores harnessing the latest technology to win a retail war against the supermarkets.

The stores are part of a voluntary grocery club called Zen Nippon Shokuhin, which since 1962 has acted as a wholesaler to its "mom-and-pop" members. Zen Nippon does not simply buy and distribute goods. It also collects consumer data from its members, which it analyses to guide them as to what their customers prefer.

One of its models is Tesco, Britain's biggest supermarket chain-which, ironically, is often accused of fatally undercutting independent local shops on its home turf. In 2009 Zen Nippon's president, Mitsuhiro Saito, sent six employees to Oxford to learn about Tesco's loyalty-card scheme. They were interested in how the firm uses data derived from the cards to understand not only what people are buying, but also how changes in lifestyle can affect shopping habits. Peter Wray, a British retail consultant who advised Zen Nippon on Tesco's loyalty system, says its approach sets it apart from the co-op industry internationally, which tends to analyse only what it sells wholesale. Since September Zen Nippon has used technology from an Israeli firm, Retalix, to introduce loyalty cards for shoppers that offer them electronic discounts on their most-purchased items. The information derived from this scheme enables Zen Nippon to bargain with brands for better deals. The programme started with 100 shops and will be rolled out to 1,000 by 2012 . The Tsukiji store hopes to take part. Mr Kojima says that, with food prices rising, he wants to give his customers even more personal treatment. 
In one sense, this is all a bit circular. As Mr Wray puts it, Tesco mines its loyalty data to help it deliver to shoppers the personal attention they used to expect from a local store. In Zen Nippon's case, the local store will use data to make itself even friendlier.

But in Japan it is a pioneering effort. In contrast to the high-tech nature of much of the rest of the economy, Japan's supermarkets are technophobic and expect little change in shopping habits. This is myopic, Mr Saito believes, adding that one of the biggest supermarkets recently approached him for advice.

Thanks to the new approach, Mr Saito says sales were $¥ 100$ billion last year, a $20 \%$ rise from the doldrums six years ago that forced him to rethink his business. That performance is particularly impressive in a deflationary economy. On January 25th the Japan Chain Stores Association said that supermarket sales in 2010 fell for the 14th year in a row.

For all the sophisticated number-crunching that his firm undertakes, Mr Saito still shares the "us-against-them" mentality of small grocers everywhere. He chuckles: "If there are any small stores left in Britain, we'd be happy to help them."

Disponível em

$<$ http://www.pearsonlongman.com/intelligent_business/teachers_resource.html $>$

Acesso em: 19 jul. 2012.

Artigo M- CNN 
The global village is a product of the media. CNN World Report has 130 reporters covering 200 different countries 'the American Way'. According to Asia Week, the head of

5 News Corporation, Rupert Murdoch, is the fourth most powerful man in Asia. Murdoch owns eight international newspapers and many of the world's biggest film, television and Internet companies. The Washington Post called him the global village's communications minister'.

10 Satellites do not respect national borders. MTV has gone where the CIA never could - into 400 million homes globally. Its influence on young consumers is huge. 200,000 Russian youths gathered in Moscow's Red Square to listen to bands sponsored by The GAP, Ericsson and Shiseido.

15 One four-week sales promotion on the music channel resulted in an amazing 30\% rise in sales for Levis. MTV's Bill Roedy says 'We're always trying to fight the stereotype that MTV is importing American culture.' At the same time, he adds: 'We want MTV in every home.' Polish president,

20 Aleksandr Kwasniewski, sums it up: 'We have to realise that MTV is more powerful than NATO:

Artigo N- The fall of Enron 


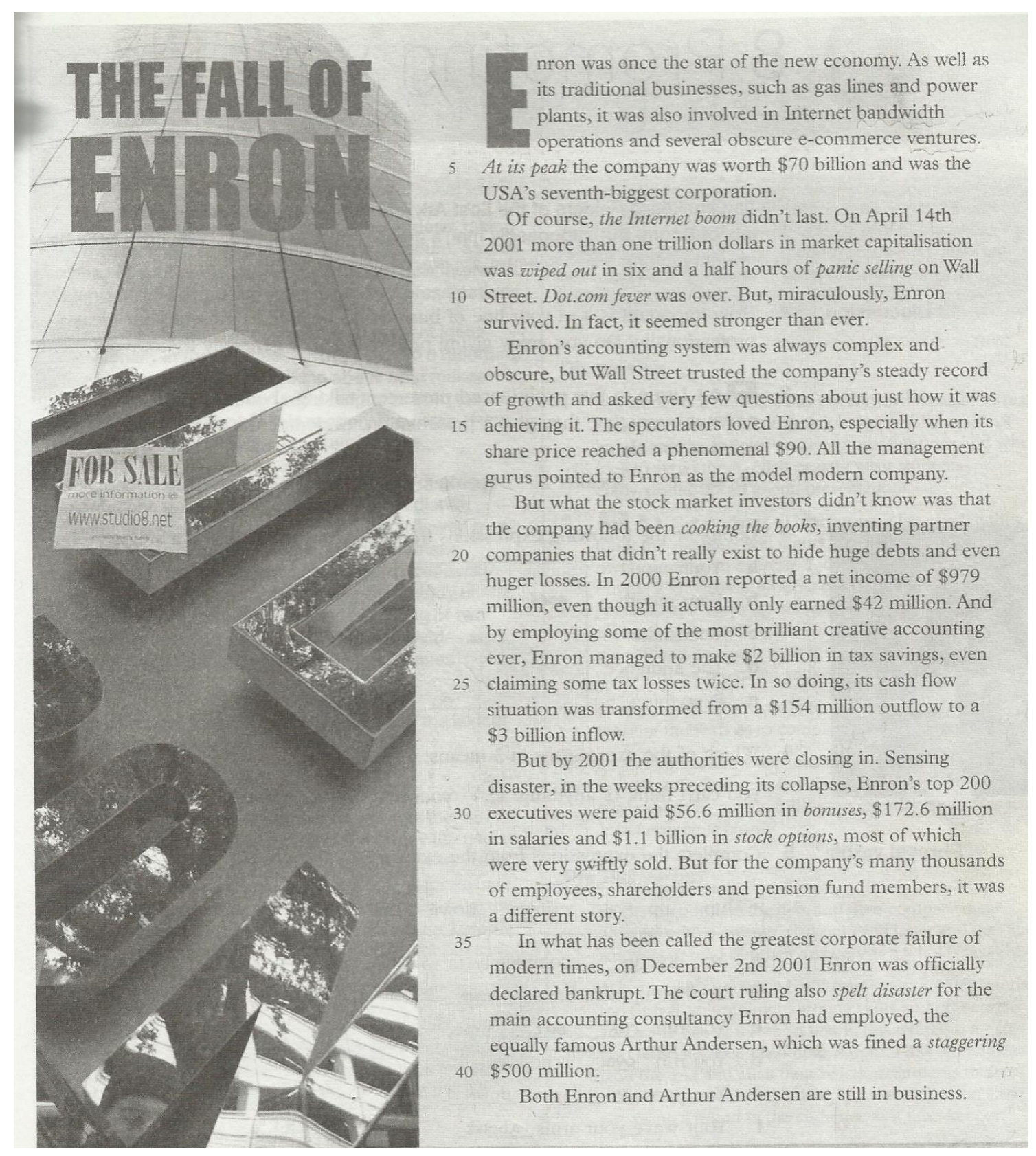


